\title{
The Efficient Synthesis of Azasugars from Pentoses
}

\author{
By \\ Michael Alan Meijlink
}

\begin{abstract}
A thesis
submitted to the Victoria University of Wellington in fulfilment of the requirements for the degree of Master of Science in Chemistry
\end{abstract}




\begin{abstract}
Azasugars [e.g., 1-deoxy-aza-xylopyranose (1) Figure 1] are structural analogues of sugars [e.g., $\alpha$-Dxylopyranose (2)] where the ring oxygen is substituted by a nitrogen atom. The resemblance of azasugars to their carbohydrate counterparts gives them various biological properties, such as the inhibition of glycosidase and glycosyltransferase enzymes, ${ }^{1}$ and as such, these compounds have been in clinical trials for the treatment of AIDS, diabetes, and cancer. ${ }^{2}$
\end{abstract}

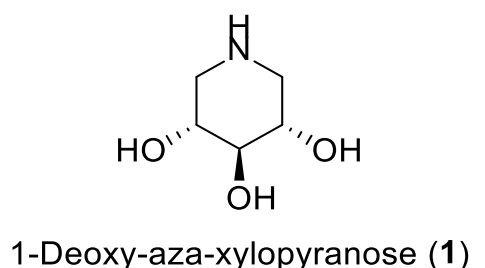

Figure 1: A representative sugar (2) and its azasugar analogue (1)

Synthetic routes to azasugars have often involved the use of protecting groups, and therefore have generally reduced efficiency by requiring additional steps to apply or remove protecting groups or requiring adjustment of stereochemistry during the synthesis. ${ }^{3}$ This thesis presents the first example of a synthesis of four sterochemically different piperidine triols through a four-step methodology minimising the use of protecting groups starting from pentoses. The synthesis of D-xylose derived $(3 \mathrm{R}, 4 r, 5 S)$-piperidine triol was previously obtained in $40 \%$ yield over five steps, ${ }^{4}$ but was afforded in $45 \%$ overall yield over four steps using the methodology described within this thesis. Next, Dribose derived $(3 R, 4 s, 5 S)$-piperidine triol was obtained in $40 \%$ overall yield over four steps, which afforded a vast improvement on the previous most efficient synthetic route obtaining the azasugar in $24 \%$ yield over four steps. ${ }^{5}$ This four-step three-pot methodology has thus allowed for the synthesis of these piperidine triols in overall yields ranging from 4-69\%, surpassing previous total syntheses in efficiency and improving overall atom economy. To further probe the applicability of the methodology, $N$-alkyl analogues (such as butyl-, phenylethyl-, and hydroxyethyl-analogues) of all four different piperidine triols were synthesised in comparable or greater overall yields compared to literature reports without any required adaptation to the original procedure. Included in these $\mathrm{N}$-alkyl analogues are seven novel azasugars which were obtained in overall yields ranging from 6$35 \%$. 


\section{Table of contents}

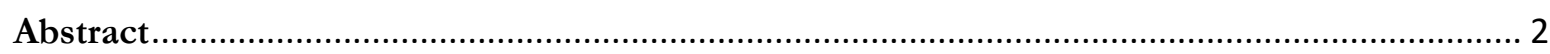

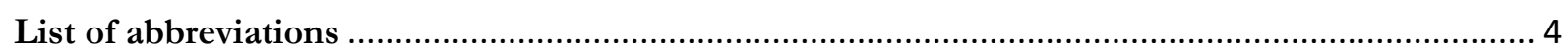

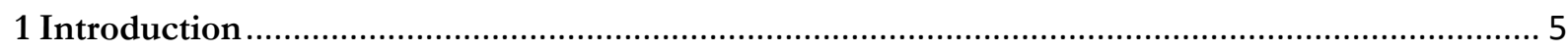

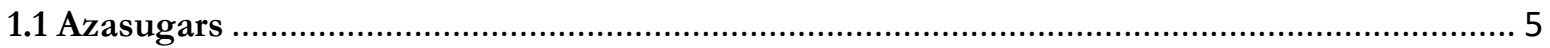

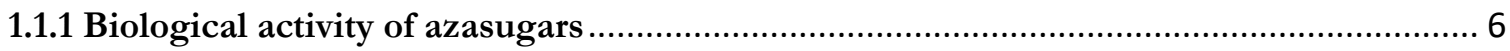

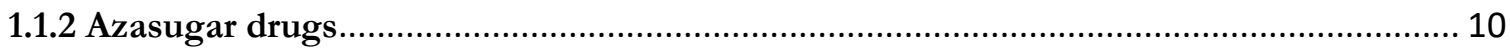

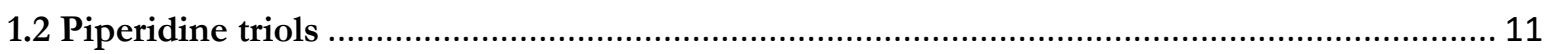

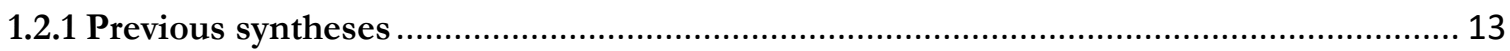

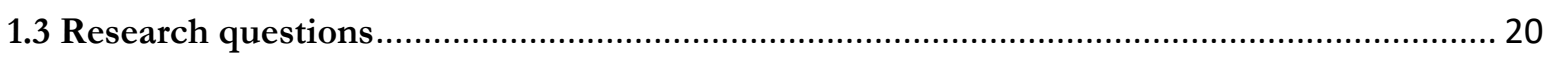

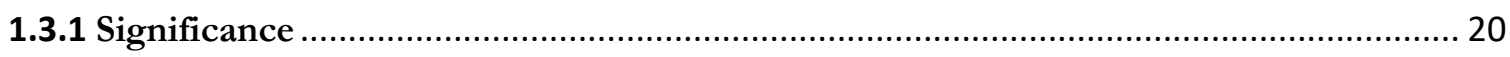

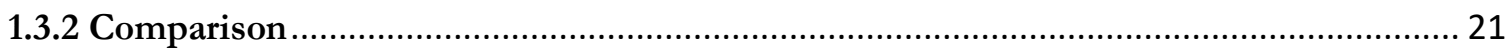

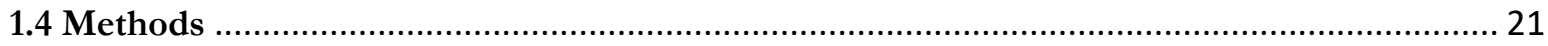

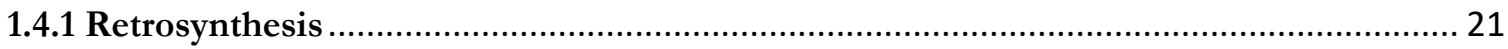

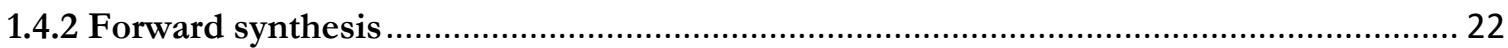

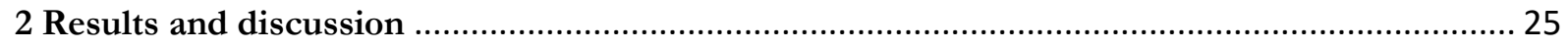

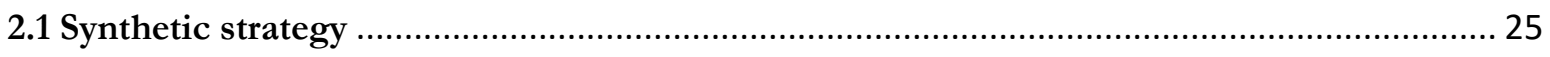

$2.2 \mathrm{D}$-xylose derived piperidine triols ....................................................................... 28

2.2.1 The synthesis of $(3 R, 4 r, 5 S)$-piperidine triol from $\mathrm{D}$-xylose ..................................... 28

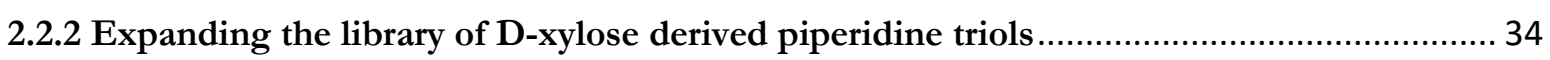

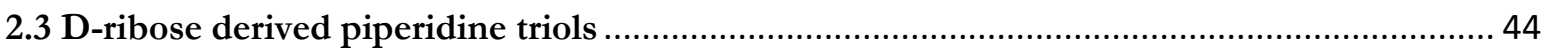

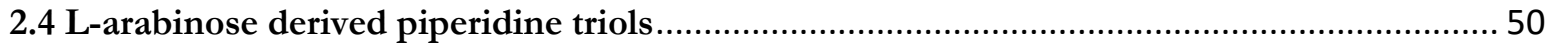

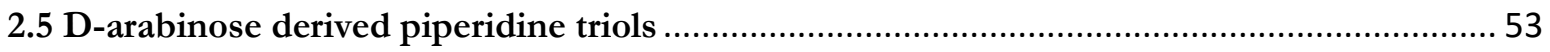

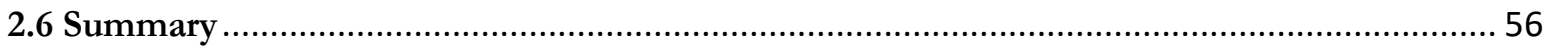

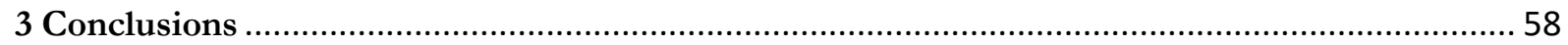

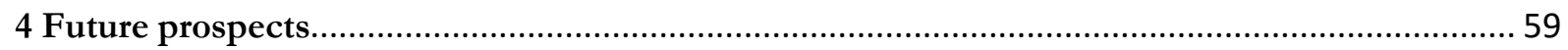

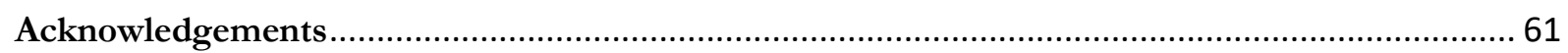

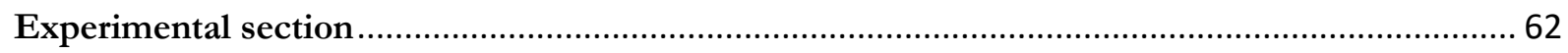

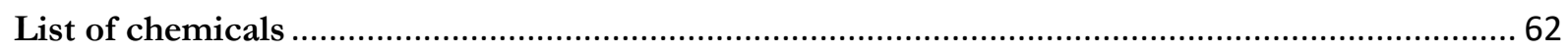

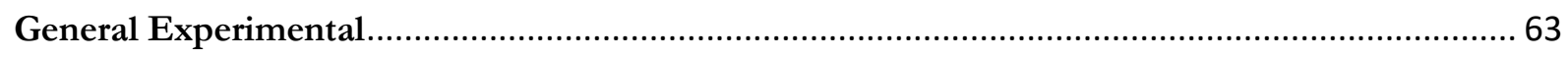

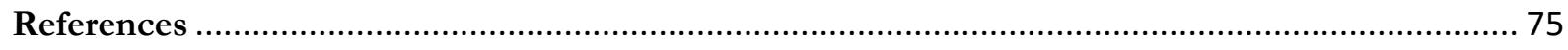

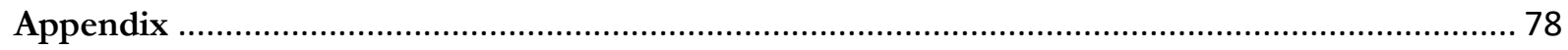




\section{List of abbreviations}

\section{Chemicals}

Ac

Acetyl

Boc

tert-Butyloxycarbonyl

DCM

Dichloromethane

$\mathrm{DNJ}$

1-Deoxynojirimycin

DMJ 1-Deoxymannojirimycin

MOM Methoxymethyl

PMP

para-Methoxyphenyl

TFA

Trifluoroacetic acid

THF

Tetrahydrofuran

Analysis

${ }^{1} \mathrm{H}-\mathrm{NMR} \quad$ Proton Nuclear Magnetic Resonance spectroscopy

${ }^{13}$ C-NMR Carbon-13 Nuclear Magnetic Resonance spectroscopy

COSY Correlation spectroscopy

HSQC Heteronuclear Single-Quantum Correlation spectroscopy

HMBC Heteronuclear Multiple Bond Correlation spectroscopy

LC-MS Liquid Chromatography-Mass Spectrometry

FT-IR Fourier Transform Infrared spectroscopy

TLC Thin Layer Chromatography

\section{Terms}

IC $_{50}$ Inhibitory concentration where enzyme activity is halved

$K_{i} \quad$ Inhibitory constant

LSDs Lysosomal Storage Diseases 


\section{Introduction}

\subsection{Azasugars}

Azasugars are described as structural analogues of sugars in which the ring oxygen is substituted by a nitrogen atom. ${ }^{1}$ There are many different types of azasugars that are generally divided into five main classes; piperidines, pyrrolidines, pyrrolizidines, indolizines and, nortropanes (Figure 2). The hydroxylated piperidines (3) and pyrrolidines (4) are among the simplest azasugars, bearing a sixmembered and five-membered ring respectively. Next, the indolizidines (5) and pyrrolizidines (6) are bicyclic azasugars containing fused five-six and five-five membered ring systems respectively. Lastly, the bicyclic nortropanes (7) feature 2,6-fused five-six membered rings.<smiles>OC1(O)CCCNC1</smiles>

\section{Piperidines}

3<smiles>OC1CCNC1</smiles>

Pyrrolidines

4<smiles>OC1CCCN2CCC(O)(O)C12</smiles>

Indolizines

5<smiles>OC1CCN2CCCC2(O)C1</smiles>

Pyrrolizidines

6

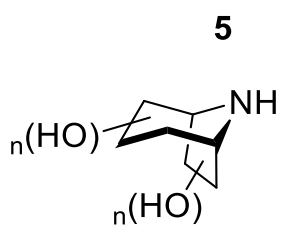

Nortropanes

7

Figure 2: The chemical structures of the five main classes of azasugars

The history of azasugars began in the early 1960s when Paulsen, ${ }^{2-3}$ Jones $^{4-5}$ and Hanessian ${ }^{6-7}$ reported on the derivatisation of sugars to incorporate a ring nitrogen instead of an oxygen. Among the first syntheses was the synthesis of the well-known azasugar 1-deoxynojirimycin (DNJ, 8, Figure 3), done in 1966 by Paulsen. ${ }^{8}$ Though it wasn't until Inouye and co-workers isolated nojirimycin (9) in 1966 from strains of Streptomyces that the interest in azasugars began to develop. ${ }^{1}$ Following this, the first biological studies were done on nojirimycin in 1968 and showed that nojirimycin had antibiotic properties against certain strains of bacteria.' However, both the synthesis and isolation of nojirimycin at the time were reported to be difficult due to its instability under neutral and acidic environments. ${ }^{9}$ Subsequently, it was found that DNJ displayed biological activity as an $\alpha$-glycosidase inhibitor, which led to an increased interest in azasugars and their analogues. ${ }^{1}$ 
<smiles>OC[C@H]1NC[C@@H](O)[C@H](O)[C@H]1O</smiles>

DNJ<smiles>OC[C@H]1N[C@H](O)[C@@H](O)[C@H](O)[C@H]1O</smiles>

Nojirimycin

9

Figure 3: Examples of common azasugars, including 1-deoxynojirimycin (8) and nojirimycin (9)

\subsubsection{Biological activity of azasugars}

\subsubsection{Glycosidase and glycosyltransferase inhibition}

Azasugars have the ability to inhibit carbohydrate-processing enzymes such as glycosyltransferases and glycoside hydrolases. The use of glycosidase inhibitors allows for the careful moderation of carbohydrate metabolism. This introduces several therapeutic uses such as in the treatment of hepatitis $\mathrm{B},{ }^{10} \mathrm{HIV},{ }^{11-12}$ diabetes $^{1}$ and cancer. ${ }^{13}$

Glycosyltransferases are enzymes that catalyse the formation of a glycosidic bond by use of an activated donor that typically contains a nucleoside phosphate or lipid phosphate leaving group. Glycosyltransferase enzymes can act through two different mechanisms: the inversion mechanism and the retaining mechanism. In the proposed inverting mechanism, a carboxylate serves as a base catalyst by activating the acceptor to attack 10 through deprotonation (Scheme 1), leading to 11. An $\mathrm{S}_{\mathrm{N}} 2$-like displacement then occurs as the phosphate group leaves, forming the resulting product $12 .^{14}$ 


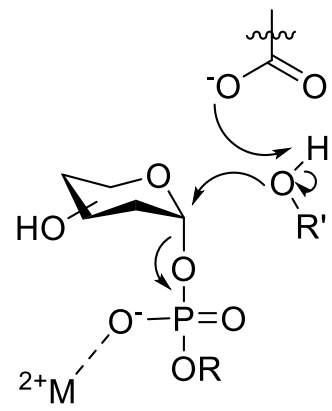

10

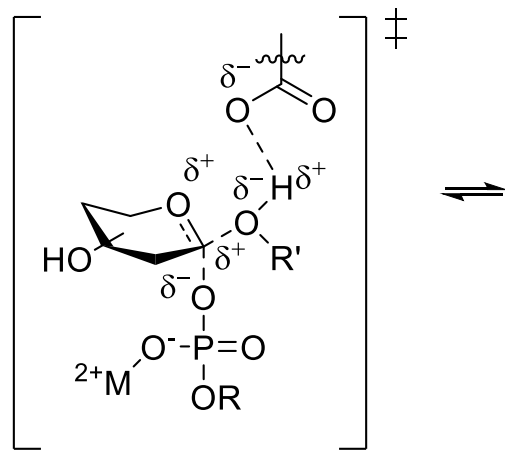

11<smiles>CC(C)(C)O</smiles><smiles>[R]O[C@H]1C[C@@H](O)CO[C@@H]1O</smiles><smiles>[Y20]OP(=O)(O)O</smiles>

12

Scheme 1: The accepted inversion mechanism of glycosidic bond transfer by glycosyltransfer enzymes. Abbreviations: R: a nucleoside, nucleoside monophosphate, lipid phosphate or phosphate and R'OH: an acceptor group such as a sugar, protein or antibiotic. Adapted from Withers et al.14

Conversely, the retaining mechanism is suggested to occur through a double-displacement mechanism of phosphate 13, where a covalently bound glycosyl-enzyme intermediate 14 is formed (Scheme 2). The incoming nucleophile of the acceptor is then deprotonated by the metal-bound phosphate, followed by an $S_{N} 2$ displacement that results in the product 15 .

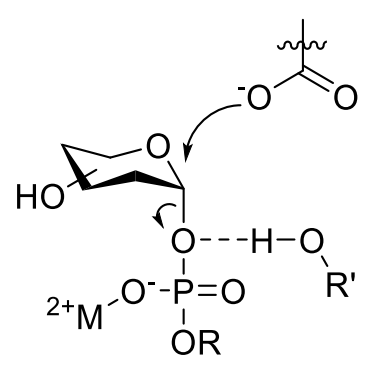

13

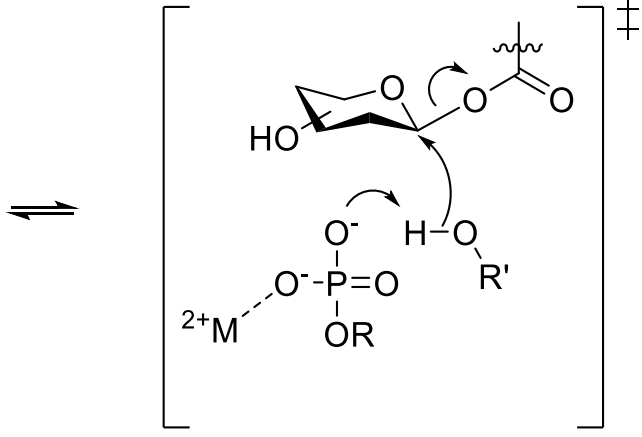

14

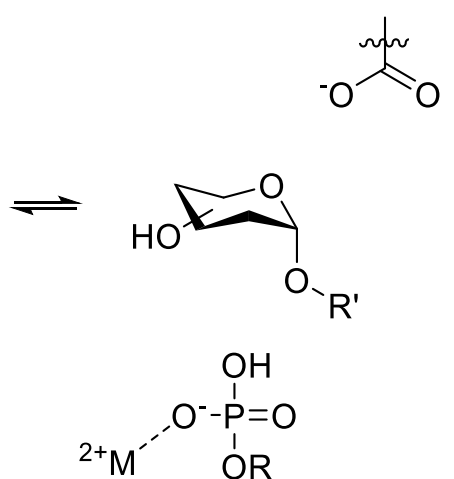

15

Scheme 2: The accepted retaining mechanisms of glycosidic bond transfer by glycosyltransferase enzymes. Abbreviations: R: a nucleoside, nucleoside monophosphate, lipid phosphate or phosphate and R'OH: an acceptor group such as a sugar, protein or antibiotic. Adapted from Withers et al. ${ }^{14}$

Another application of azasugars is as glycoside hydrolase inhibitors, such as in the treatment of type II diabetes. Glycoside hydrolases are enzymes that catalyse the hydrolysis of glycosidic bonds in polysaccharides through either inverting or retaining mechanisms. The inverting mechanism involves two carboxyl groups serving as acid and base catalysts (Scheme 3). The carboxyl groups 
are distanced an average of $9.0 \pm 1.0 \AA$ apart in $\alpha$-glycoside hydrolases and $9.5 \AA$ apart in $\beta$ glycoside hydrolases. This allows for the positioning and binding of a water molecule between the carboxyl groups and the substrate $\mathbf{1 6}$ as seen in transition state 17. The formation of $\mathbf{1 8}$ occurs through an SN2-like substitution, resulting in both the free sugar and the remaining glycosidic chain. $^{15}$

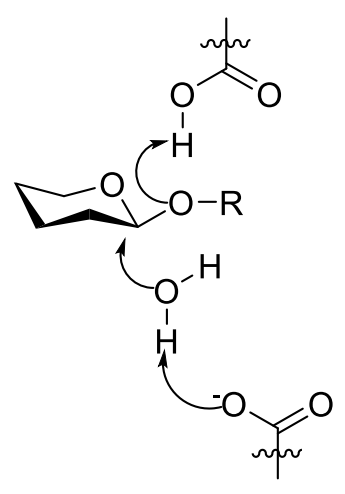

16

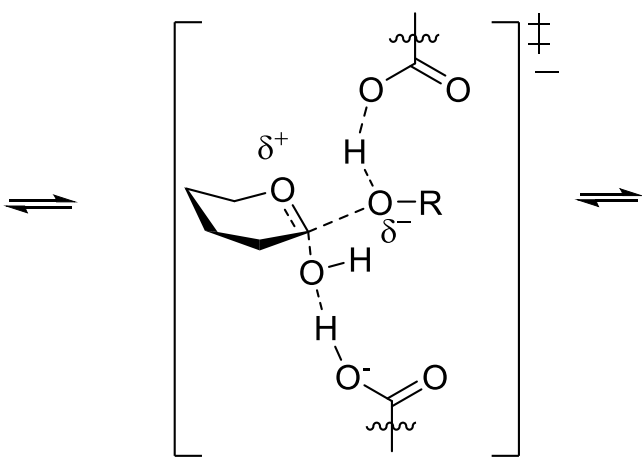

17

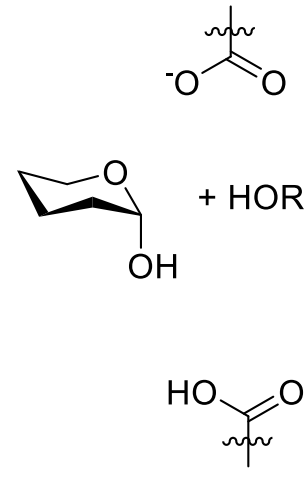

18

Scheme 3: The accepted inversion mechanisms of glycosidic bond hydrolysis by glycoside hydrolase enzymes. Adapted from Withers et al. ${ }^{15}$

The retaining mechanism resembles the inverting mechanism in that it also involves an oxocarbenium ion-like transition state and includes two carboxyl groups (Scheme 4). In this mechanism, one of the carboxyl groups functions as an acid/base catalyst, and the other functions as a nucleophile/leaving group. Initially, one of the carboxyl groups protonates the glycosidic oxygen of the substrate while the other carboxyl group functions as a nucleophile (19), resulting in substrate-enzyme transition state 20. Next, the free carboxyl group deprotonates a water molecule, prompting a nucleophilic attack of water to the anomeric carbon of intermediate 21 to form the oxocarbenium transition state 22 . As the carboxyl group is displaced by the water, the product $\mathbf{2 3}$ forms. The distance between the carboxyl groups and the substrate is substantially shorter than in the inverting mechanism, with an average of $4.8 \pm 0.5$ in $\alpha$-glycoside hydrolases and $5.3 \pm 0.2$ in $\beta$ glycoside hydrolases. The retention of stereochemistry occurs through a double-displacement mechanism involving a glycosyl-enzyme intermediate. ${ }^{16}$ 


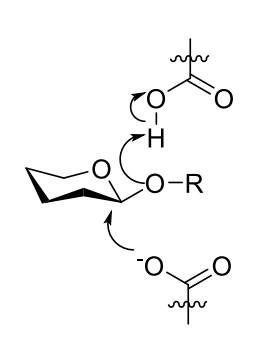

19

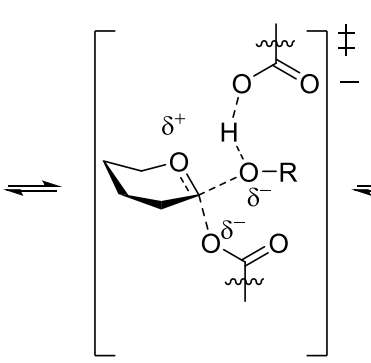

20

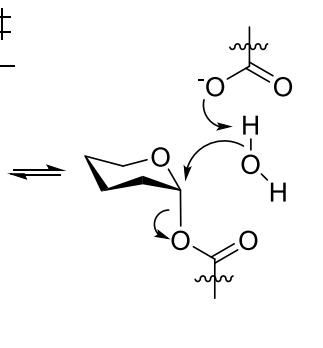

21

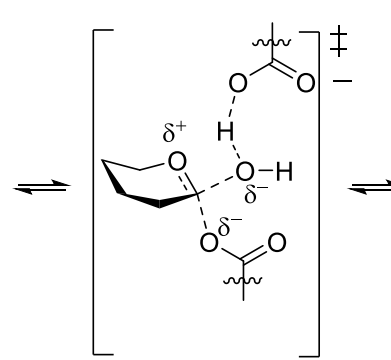

22
HO $\overbrace{\mathrm{O}}^{\text {n }}$<smiles>CC(C)(C)OC(=O)OC1CCCCC1</smiles>

23

Scheme 4: The accepted retaining mechanisms of glycosidic bond hydrolysis by glycoside hydrolase enzymes. Adapted from Withers et al. ${ }^{15}$

What makes azasugars potent inhibitors of these enzymes is their ability to mimic the pyranose or furanose transition states of glucosidase catalysed reactions (Scheme 5). The suggested mechanism for this inhibition proceeds by the azasugar mimicking the oxocarbenium ion in its transition state. ${ }^{17}$ The nitrogen atom of azasugars is protonated at physiological $\mathrm{pH}$ (24), which then mimics the positive charge of the oxocarbenium cation $\mathbf{2 5}$ observed during glycosidic bond transfer and hydrolysis mechanisms. ${ }^{17}$

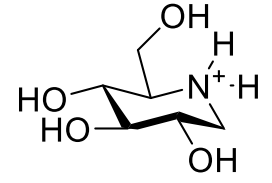

Oxocarbenium ion mimic<smiles>C[O+]1CC(O)C(O)C(O)C1CO</smiles>

Oxocarbenium ion

Scheme 5: The protonation of an azasugar to form the oxocarbenium ion mimic.

Adapted from de Melo et al. 200618 


\subsubsection{Pharmacological chaperones}

Azasugars have also found potential in the treatment of Lysosomal Storage Diseases (LSDs). LSDs encompass a wide array of rare diseases with an estimated prevalence of at least 1 in 5000 births. ${ }^{19}$ Although the specific symptoms of each individual LSD differ, their origins align as being caused by mutations in genes transcribing lysosomal enzymes. ${ }^{19}$ One of many possible consequences of such mutations is the incorrect folding of enzymes, which reduces catalytic activity by preventing the enzyme from reaching the lysosome to bind with the substrate. ${ }^{20}$ The loss of lysosomal enzyme activity then results in accumulation of substrates within the lysosome, which may then result in the various symptoms observed in LSDs. ${ }^{21}$ Azasugars have been found to have potential in the treatment of LSDs such as Gaucher's disease, GM1 gangliosidosis, Fabry's disease, Krabbe disease and Niemann-Pick disease type $\mathrm{C}$ specifically as molecular chaperones. ${ }^{22-23}$ Molecular chaperones are competitive inhibitors of misfolded enzymes prevalent in LSDs, and help to rearrange the enzyme back to its designated tertiary or quaternary structure. This allows the enzyme to bind to substrates and retain their structure. Once the enzyme-substrate complex has formed, the constant catalysis of substrates keeps the enzyme in its proper shape..$^{20}$

\subsubsection{Immunosuppressants}

Immunosuppressants are compounds that suppress partial activity of the immune system, most commonly used in organ allograft transplantation and in the treatment of autoimmune diseases. ${ }^{24-}$

${ }^{26}$ However, the most widely used immunosuppressants have adverse effects such as chronic kidney injuries, hypertension and proteinuria, and thus were recommended only for use in patients with life-threatening or very serious cases. ${ }^{27-28}$ An array of azasugars were observed to have immunosuppressive effects by $\mathrm{Ye} e \mathrm{al}{ }^{29}$ both in vitro, and ex vivo in a mouse skin transplant model by acting as inhibitors of cytokines IFN- $\gamma$ and IL-4. With recent advances in the potential of azasugars as immunosuppressants primarily undertaken by $\mathrm{Ye}$ et al., ${ }^{29-32}$ this field of provides exciting new alternatives for conventional immunosuppressants.

\subsubsection{Azasugar drugs}

Some noteworthy azasugar drugs on today's market include miglitol (Glyset $^{\mathrm{TM}}$ ), voglibose (Glustat $^{\mathrm{TM}}$ ), and Miglustat (Zavesca ${ }^{\mathrm{TM}}$ ) (Figure 4). Miglustat (26) was approved in 2000 for the treatment of type 1 Gaucher disease, which is a severe LSD. ${ }^{33-35}$ Miglustat (26) functions by reversibly inhibiting glucosylceramide synthase, a glycosyl transferase enzyme. This prevents the primary step in glycosphingolipid synthesis, which reduces their accumulation in lysosomes. ${ }^{36-37}$ 
This inhibitory activity also enables for the use of miglustat in Niemann-Pick disease type C, since the symptoms of this disease have been linked to the accumulation of glycosphingolipids in cells. ${ }^{38}$ Miglitol (27) and voglibose (28) are potent $\alpha$-glucosidase inhibitors and are mainly used in the treatment of type II diabetes. ${ }^{33}$ Voglibose was released on the market as an antidiabetic agent in 1994 and featured a better tolerance than acarbose, another antidiabetic agent. ${ }^{39}$ Furthermore, voglibose does not inhibit $\alpha$-amylase activity and thus causes less adverse effects. ${ }^{40}$ Miglitol was approved in 1996 as an anti-diabetic and has since then been widely studied for its mechanism of action. ${ }^{41}$ Most recently, 1-deoxygalactonojirimycin was approved in May 2016 under the name "Migalastat" (Galafold $\left.{ }^{\mathrm{TM}}, 29\right)$ for the treatment of Fabry's disease in the $\mathrm{EU}^{42}$ and has since expanded to Australia and Canada. ${ }^{43-44}$ Fabry's disease is an LSD characterised by a deficiency in $\alpha$-galactosidase A activity. Migalastat acts as a competitive inhibitor of $\alpha$-galactosidase A, which allows it to act as a pharmacological chaperone to restore enzymatic activity in the treatment of Fabry's disease. ${ }^{45-46}$<smiles>CCCCN1C[C@H](O)[C@@H](O)[C@H](O)[C@H]1CO</smiles>

Miglustat (Zavesca)<smiles>OCCN1C[C@H](O)[C@@H](O)[C@H](O)[C@H]1CO</smiles>

Miglitol (Glyset)<smiles>OCC(CO)CN[C@H]1C[C@H](O)[C@@H](O)[C@H](O)[C@H]1O</smiles>

Voglibose (Glustat)<smiles>OC[C@H]1NC[C@@H](O)[C@H](O)[C@@H]1O</smiles>

Migalastat (Galafold)

26

Figure 4: Four azasugars that have been approved for use as drugs

\subsection{Piperidine triols}

The research described within this thesis revolves around piperidine triols (30-33), a subclass of piperidines (Figure 5). Despite containing three stereocentres, there are only four stereochemically different piperidine triols, due to the high degree of symmetry among these molecules. Historically, the piperidine triols were used in Chinese and Japanese folk medicine, functioning as diuretic, antipyretic, emmenagogue, and antidiabetic agents. ${ }^{29}$ Piperidine triols first appeared in 1965 as a product of experimentation. ${ }^{47}$ However, piperidine triols received very little attention until 1990 when $\mathrm{Ganem}^{48}$ reported a novel synthesis and their resulting biological activity. The authors found 
that these compounds were effective inhibitors of specific glycosidases such as sweet almond $\beta$ glucosidase and jackbean $\alpha$-mannosidase. Five years later, the first isolation of piperidine triols from natural sources was performed by Kusano. ${ }^{49}$ Subsequently, piperidine triols 30, 31 and 33 were isolated from Eupatorium fortunei TURZ, a plant native to Asia. ${ }^{50}$ As a result, these compounds gained interest and had multiple total syntheses published of these compounds, which will be discussed in detail below.<smiles>O[C@H]1CNC[C@@H](O)[C@@H]1O</smiles>

30<smiles>O[C@H]1CNC[C@@H](O)[C@H]1O</smiles>

31<smiles>O[C@H]1CNC[C@@H](O)[C@H]1O</smiles>

32<smiles>O[C@H]1CNC[C@@H](O)[C@@H]1O</smiles>

33

Figure 5: The chemical structure of four different stereoisomers of piperidine triols

A study in 1996 by Ichikawa et al. ${ }^{51}$ describes the evaluation of biological activity of D-ribo-derivative 31 and the $N$-butyl analogue of D-ribo-isomer 31. It was found that D-ribo-derivative 31 and its $N$ butyl analogue were moderate inhibitors $\left(\mathrm{IC}_{50}=40 \mu \mathrm{M}\right)$ of both $\alpha$ - and $\beta$-galactosidase enzymes. Furthermore, D-xylo-isomer $\mathbf{3 0}$ was found to be a potent inhibitor of the $\beta$-glucosidase enzyme with an $\mathrm{IC}_{50}$ value of $8.8 \mu \mathrm{M} .^{51}$ The same year, Winchester et al. ${ }^{52}$ also reported a synthesis and biological studies of all four piperidine triols. The authors observed D-arabino-derivative 32 to selectively inhibit $\alpha$-fucosidase enzyme activity by over $85 \%$, and found the $\mathrm{HCl}$ salt of $\mathrm{D}-x y / 0$ isomer 30 to almost completely (97\%) inhibit $\beta$-D-glucosidase from human liver extract. ${ }^{52}$ In 2002 , Withers and co-workers ${ }^{53}$ reported on the biological activity of D-xylo-derivative $\mathbf{3 0}$ and a range of $N$-alkylated analogues of D-xylo-isomer 30. It was found that $\mathrm{D}$-xylo-derivative $\mathbf{3 0}$ was a moderate inhibitor $\left(K_{i}=50 \mu \mathrm{M}\right)$ of the $\beta$-glucosidase enzyme, but all derivatives led to significant loss of inhibitory activity to this enzyme. Conversely, D-xylo-derivative $\mathbf{3 0}$ was found to be a moderately poor inhibitor of the $\beta$-xylosidase enzyme $\left(K_{i}=206 \mu \mathrm{M}\right)$, yet $N$-alkylated derivatives increased inhibitory activity up to an $\mathrm{IC}_{50}$ of $25 \mu \mathrm{M}$ for the ethyl nitrile derivative. ${ }^{53} \mathrm{~A}$ study from 2005 by Strynadka et al..$^{54}$ describes the activity of D-xylo-isomer $\mathbf{3 0}$ as a potent inhibitor $\left(K_{i}=0.9 \mu \mathrm{M}\right)$ of the $\alpha$-xylosidase enzyme, which is an almost 50 -fold more potent inhibition than DNJ with a $K_{i}$ of $130 \mu \mathrm{M}$. A year later, Asano et al. ${ }^{55}$ studied the activity of piperidine triols in glucosylceramide $\beta$ glucosidase enzymes and determined the $K_{i}$ of some piperidine triols to be much more potent than that of DNJ. In 2011, Ye et al..$^{29}$ found the first evidence of immunosuppressive effects of $N$ - 
substituted derivatives of piperidine triols by inhibiting the proliferation of splenocytes and secretion of some hallmark cytokines of Th1 and Th2 cells in mice.

\subsubsection{Previous syntheses}

\subsubsection{Literature syntheses}

The first synthesis of piperidine triol azasugars was achieved in 1965 by Paulsen, ${ }^{47}$ who obtained the azasugar as a product while exploring the synthetic potential of elimination product 38 (Scheme 6). This synthesis started from D-glucose (34) and in four steps the protected xylose derivative $\mathbf{3 5}$ was prepared. ${ }^{47}$ The acidic hydrolysis of xylose derivative 35 in methanol gave methyl aminoglycoside 36 in 40\% yield. Under acidic conditions, the methyl group of methyl amino-glycoside 36 is deprotected and the lactol product can convert to its linear aldehyde form. The linear aldehyde of methyl deprotected $\mathbf{3 6}$ then undergoes subsequent rapid intramolecular nucleophilic attack to form azasugar 37, which is in equilibrium with its corresponding imine form 38. Hydrogenation of azasugar 38 by use of hydrogen on platinum resulted in azasugar 30 in $96 \%$ yield.<smiles>OC[C@H]1O[C@H](O)[C@@H](O)[C@H](O)[C@H]1O</smiles>

34<smiles>NC[C@H]1O[C@@H]2OC3(CCCCC3)O[C@H]2C1O</smiles>

35<smiles>COC(OC)[C@H](O)CN</smiles>

36<smiles>[3H][13OH]</smiles><smiles>O[C@H]1CN[C@@H](O)[C@H](O)[C@H]1O</smiles>

37

Scheme 6: The first synthetic route towards azasugar 30 performed by Hans Paulsen in 196547

The study by Ichikawa et al. ${ }^{51}$ in 1996 describes the synthesis of piperidine triols and N-butyl analogues. The employed synthetic route (Scheme 7) highlights the common use of protecting groups in the synthesis of these azasugars. The total synthesis starts with the isopropylidene protection of D-ribose (39) at the 2- and 3-positions. Next, pentose 40 was tosylated at the 5position followed by benzoyl protection at the anomeric position to give $\mathbf{4 1}$ in $48 \%$ yield over the 
three steps. Protected sugar 41 was subjected to sodium azide to give product $\mathbf{4 2}$ in $91 \%$ yield. Next, the benzoyl protecting group was removed with sodium methoxide and subsequent intramolecular reductive amination in the presence of $\mathrm{H}_{2}-\mathrm{Pd}(\mathrm{OH})_{2}$ resulted in the isopropylidene protected azasugar 43 in 75\% yield over two steps. The ring nitrogen was then protected with a Boc protecting group for the synthesis of a different synthetic target. To obtain azasugar 31, the authors deprotected azasugar 44, which gave azasugar 31 in $90-95 \%$ yield. Lastly, the $N$-butyl derivative was obtained by subjecting azasugar 31 to $n$-butyraldehyde and $\mathrm{BH}_{3} \bullet$ pyridine in a $\mathrm{MeOH}$ phosphate buffer, giving azasugar $\mathbf{4 5}$ in 80\% yield. The route towards the synthesis of azasugar 31 resulted in a $22 \%$ overall yield over 8 steps and the $N$-butyl substituted analogue was formed in $18 \%$ overall yield over 9 steps.

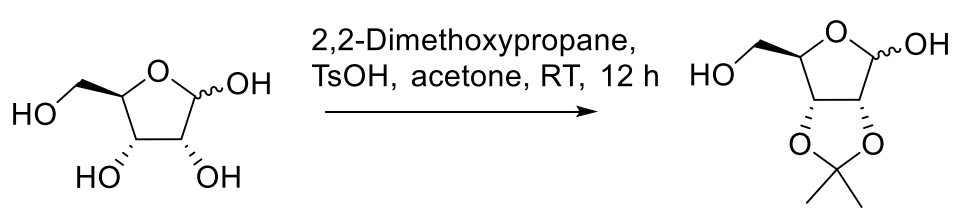

39 (i) $\mathrm{TsCl}$, Pyridine $0-5{ }^{\circ} \mathrm{C}, 10 \mathrm{~h}$

(ii) $\mathrm{BzCl}$, Pyridine, $0-5{ }^{\circ} \mathrm{C}, 1 \mathrm{~h}$

$48 \%$ over 3 steps<smiles>CC(C)(C)O[C@H]1O[C@H](CO[AsH3])[C@@H]2OC(C)(C)O[C@@H]21</smiles>

41<smiles>CC(C)(C)OC(=O)N1C[C@H](O)[C@H]2OC(C)(C)O[C@H]2C1</smiles>

BocON, $\mathrm{Et}_{3} \mathrm{~N}$, $\mathrm{H}_{2} \mathrm{O}$-dioxane, RT, $8 \mathrm{~h}$ $73 \%$<smiles>CC1(C)O[C@H]2CNC[C@@H](O)[C@H]2O1</smiles>

43 (i) $\mathrm{NaOMe}, \mathrm{MeOH}$, $\mathrm{RT}, 10 \mathrm{~min}$ (ii) $\mathrm{H}_{2} / \mathrm{Pd}(\mathrm{OH})_{2}$, $\mathrm{MeOH}-\mathrm{H}_{2} \mathrm{O}$, RT, $12 \mathrm{~h}$

$75 \%$ over 2 steps<smiles>CC(C)(C)O[C@@H]1O[C@H](CN)[C@@H]2OC(C)(C)O[C@H]12</smiles>
42

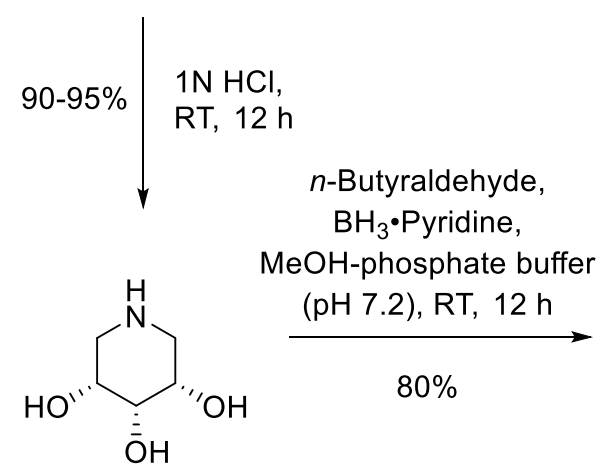

31<smiles>CCCCN1C[C@H](O)[C@H](O)[C@H](O)C1</smiles>

45

Scheme 7: The synthetic route towards azasugar 31 and its corresponding $\mathrm{N}$-butyl substituted analogue 45 performed by Ichikawa et al. in 199651 
A route towards the synthesis of the $\mathrm{HCl}$ salts of azasugars $\mathbf{3 0}$ and $\mathbf{3 3}$ starting from an achiral reagent was published in 2003 by $\mathrm{Han}^{56}$ (Scheme 8). Alkene 46 was subjected to regioselective aminohydroxylation using (DHQD) $)_{2}$ PHAL catalysed by potassium osmate and yielded the aminoalcohol 47 in 9:1 S:R enantioselectivity and in 63\% yield. Next, the hydroxy group was reacted with $\mathrm{MOMBr}$ to give the MOM-protected amine 48 in $63 \%$ yield. Subsequently, the $N$ acetyl underwent $N$-Boc protection followed by deacetylation to give Boc-amide 49 in $85 \%$ yield. Boc-amide 49 was then subjected to $N$-allylation using allyl bromide and potassium hydride, resulting in amide $\mathbf{5 0}$ in 97\% yield. PMP deprotection was achieved using ceric ammonium nitrate, which gave aminoalcohol 51 in 73\% yield. Swern oxidation of aminoalcohol 51, which gave aldehyde $\mathbf{5 2}$ in $\mathbf{7 3} \%$ yield. Aldehyde $\mathbf{5 2}$ was then converted to ester $\mathbf{5 3}$ by a modified HornerWadsworth-Emmons reaction in 88\% yield. Ester $\mathbf{5 3}$ underwent ring closing metathesis using Grubbs' $2^{\text {nd }}$ generation catalyst, resulting in cyclic olefin $\mathbf{5 4}$ in $89 \%$ yield. The Upjohn dihydroxylation of olefin $\mathbf{5 4}$ resulted in protected azasugar $\mathbf{5 5}$ in 98\% yield. Subsequent acidic hydrolysis gave the $\mathrm{HCl}$ salt of azasugar $\mathbf{3 3}$ in 94\% yield. Alternatively, protected azasugar $\mathbf{5 5}$ was treated with thionyl chloride, yielding cyclic sulfate $\mathbf{5 6}$ in 88\% yield. Ring opening by addition of sodium benzoate followed by acidic hydrolysis resulted in azasugar 30 in $90 \%$ yield. The divergent synthesis of the $\mathrm{HCl}$ salt of azasugar 33 was achieved in 13\% overall yield over 12 steps and azasugar 31 in 11\% overall yield over 15 steps. 


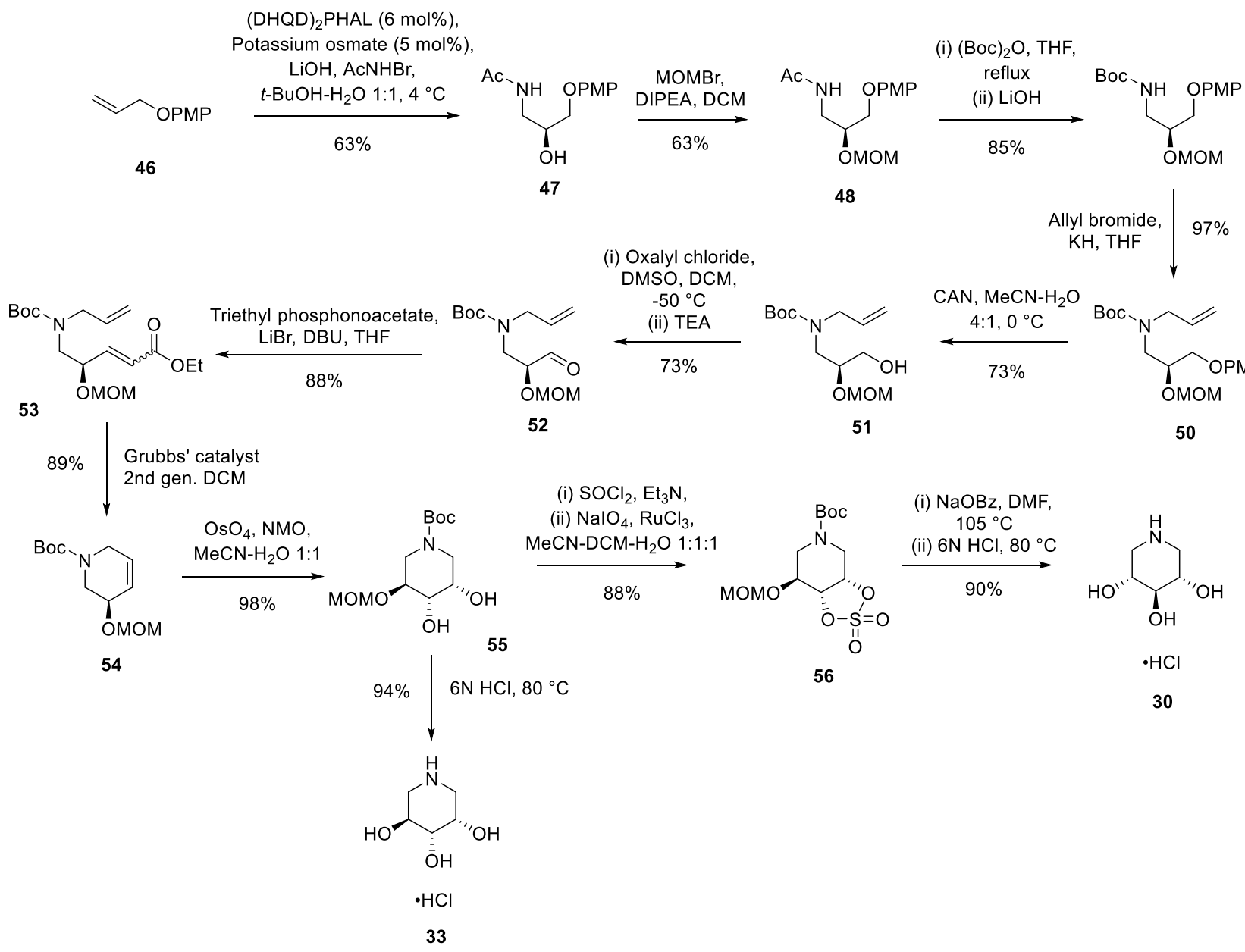

Scheme 8: The synthetic route towards the $\mathrm{HCl}$ salts of azasugars 30 and 33 performed by Han in 200356

The most recently published total synthesis of piperidine triols was done by Martin et al., ${ }^{57}$ who obtained multiple azasugar derivatives for biological studies of galactosidase enzyme inhibition (Scheme 9). Starting from D-ribose (39), the 2- and 3- positions were protected with an isopropylidene protecting group using acetone under strong acidic conditions. Subsequently, the anomeric position was benzyl protected using benzyl alcohol to give protected pentoside $\mathbf{5 7}$ in 33\% yield over two steps. Following protection, Dess-Martin oxidation of the 5-hydroxy group was achieved in quantitative yield. Addition of amine under mild acidic conditions in the presence of a reducing agent allowed for anomeric deprotection and double reductive amination of aldehyde $\mathbf{5 8}$ to give azasugar 59 in 25-91\% yield. Lastly, the deprotection of the isopropylidene group using acidic Dowex $\left(\mathrm{H}^{+}\right)$exchange resin resulted in the azasugar derivative 60 in 59-91\% yield. The synthesis of these derivatives was achieved in an average overall yield of 14\% over five steps. Most notably, the greatest loss in yield occured at the start of the synthesis in the isopropylidene- and 
benzyl-protection steps. This synthetic strategy makes use of an efficient reductive amination step where derivatisation is possible without the incorporation of extra steps. This provides a great advantage over other synthetic routes, where nitrogen is introduced through sources such as $N$ bromoacetamide.

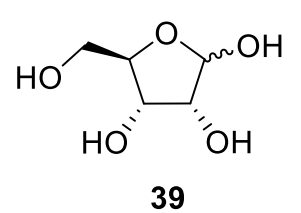

39 (i) $\mathrm{H}_{2} \mathrm{SO}_{4}$, acetone,

$\mathrm{RT}, 2 \mathrm{~h}$

(ii) Benzyl alcohol, benzene, $3 \mathrm{~h}$

$33 \%$

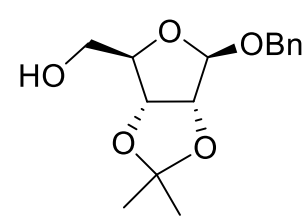

57

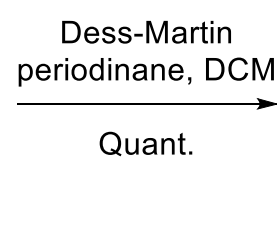

Dess-Martin

Quant.

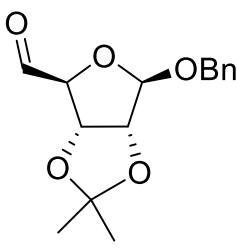

58

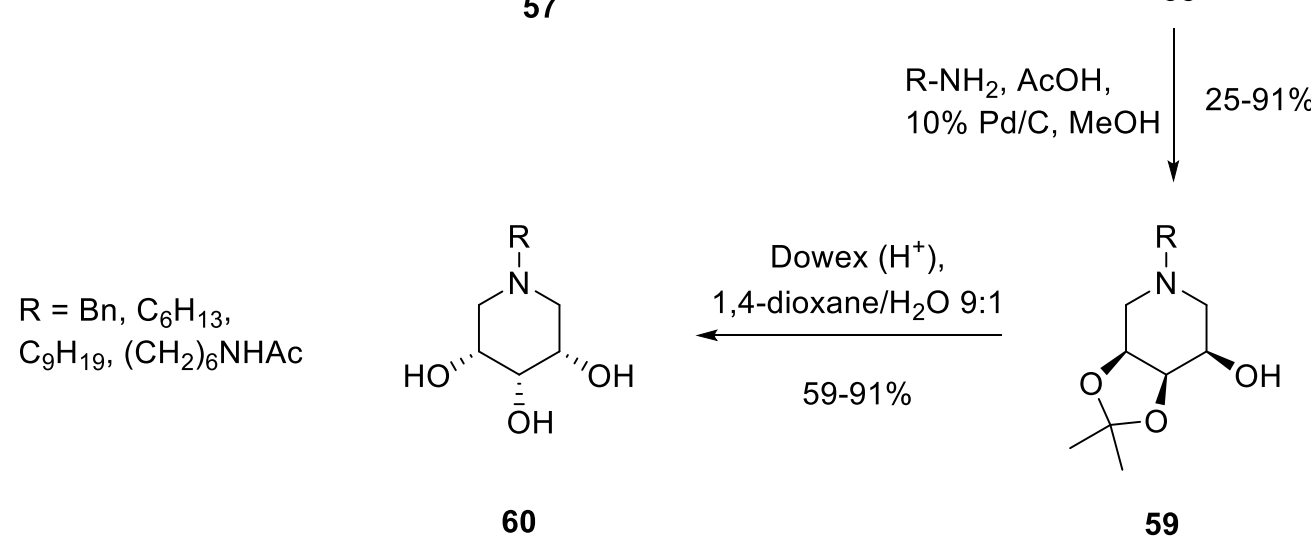

Scheme 9: The most recent total synthesis of $\mathrm{N}$-alkyl analogues of azasugar 31, performed by Martin et al. in $2016{ }^{57}$

The overall conclusion to draw from previously discussed examples of total syntheses is that these deceptively simple looking compounds can be challenging to obtain. Synthetic strategies of piperidine triols always employ protecting groups, such as isopropylidene, Boc, benzyl, and benzoyl groups. Furthermore, the addition or removal of protecting groups has often been among the lower-yielding steps of these total syntheses. Avoiding the use of protecting groups would be of potential interest to increase the efficiency of the synthesis of piperidine triols. However, protecting group-free chemistry of carbohydrates has mostly been avoided for the sole reason of its complexity, as unprotected carbohydrates have many reactive hydroxyl centres which open the possibility of side-reactions. 


\subsubsection{Previous syntheses of azasugars through a protecting group minimising strategy}

Some of the most recent preceding work in this area was done by Ben Deeble ${ }^{58}$ and Alex HuntPainter ${ }^{59}$ in the Timmer and Stocker group at the Victoria University of Wellington (Scheme 10). The synthesis starts with the Fischer glycosidation of $\mathrm{D}$-fructose (61) using $\mathrm{MeOH}$ under acidic conditions, giving methyl glycoside $\mathbf{6 2}$ in 97\% yield. Next, glycoside $\mathbf{6 2}$ is iodinated under Garegg conditions using $\mathrm{I}_{2}$, resulting in the iodinated product $\mathbf{6 3}$ in $80 \%$ yield. A one-pot reaction of acidic hydrolysis of methyl iodo-glycoside 63 to 5-iodoglycoside 64, followed by reductive amination using $\mathrm{NH}_{3}$ and $\mathrm{NaCNBH}_{3}$ gave DMJ (65) in quantitative yield. Thus, DMJ was obtained in $78 \%$ overall yield in four steps from D-fructose.

(i) $\mathrm{MeOH}$, $\mathrm{H}_{2} \mathrm{SO}_{4}(0.09 \mathrm{M})$,

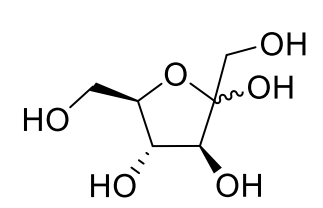

61

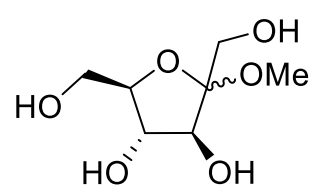

62

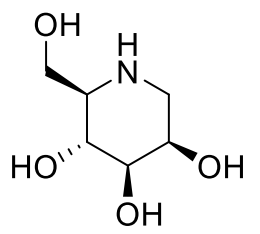

65

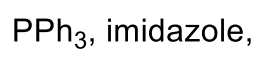

$80 \%$

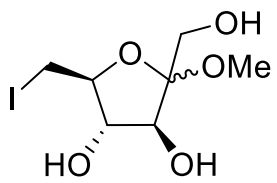

$\mathrm{H}_{2} \mathrm{SO}_{4}(9 \mathrm{mM})$,
$\mathrm{H}_{2} \mathrm{O}, \mathrm{RT}, 1 \mathrm{~h}$

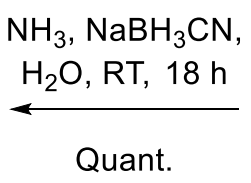

Quant.

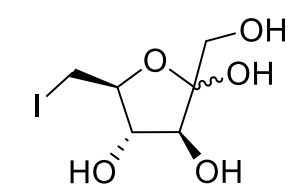

64

Scheme 10: The total synthesis of DMJ as carried out by Alex 59

Subsequently, the methodology was modified to make $N$-substituted derivatives (Scheme 11). A problem occurred during the hydrolysis reaction, as inconsistent yields were obtained ranging from $60-90 \%$. In an attempt to solve this, the reaction was attempted using a variety of acids and different concentrations. This led to a modified methodology using $2 \mathrm{M}$ aqueous $\mathrm{HCl}$ in the hydrolysis reaction for a full conversion. 
(i) $\mathrm{MeOH}$, $\mathrm{H}_{2} \mathrm{SO}_{4}(0.09 \mathrm{M})$,<smiles>OC[C@H]1O[C@](O)(CO)[C@@H](O)[C@H]1O</smiles>

61

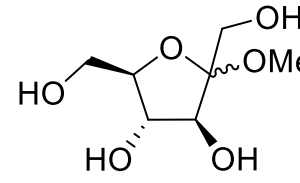

62

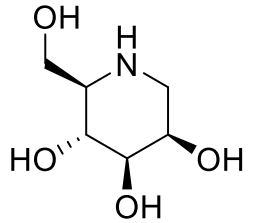

65

$\mathrm{PPh}_{3}$, imidazole,

$\mathrm{I}_{2}$ (in THF, dropwise),<smiles>CO[C@@]1(CO)O[C@H](CI)[C@@H](O)[C@H]1O</smiles>

$80 \%$

63

$\mathrm{HCl}(2 \mathrm{M})$, $\mathrm{H}_{2} \mathrm{O}, \mathrm{RT}, 1 \mathrm{~h}$

$\mathrm{NH}_{3}, \mathrm{NaBH}_{3} \mathrm{CN}$, $\mathrm{H}_{2} \mathrm{O}, \mathrm{RT}, 18 \mathrm{~h}$

$85 \%$

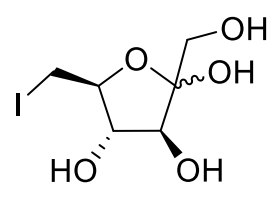

64

Scheme 11: The modified total synthetic route of DMJ as carried out by Ben ${ }^{58}$

Using the adapted methodology, DMJ (65) was prepared successfully. Further modifications were required to produce derivatives 64-72 (Scheme 12), as reduced yields were observed. This was thought to be due to a competing hydrolysis reaction of an intermediate, which would be favoured in water. Thus, EtOH was used in an attempt to prevent the hydrolysis reaction. To prevent glycosidation with $\mathrm{EtOH}$ due to acidic conditions, the reaction was concentrated and neutralised before starting the reductive amination. $N$-substituted derivatives 64-72 were obtained in total yields ranging from $28-47 \%$. No additional reactions were incorporated in the synthesis of the $N$ substituted derivatives. Instead, most of the deviation from the original procedure occurred during the workup of these compounds. 
<smiles>[R]N1C[C@H](O)[C@@H](O)[C@H](O)[C@H]1CO</smiles>

DMJ, $65 \mathrm{R}=\mathrm{H}$

$$
\mathrm{R}=\xi_{\mathrm{L}} \mathrm{Me}
$$

66<smiles>CCCc1ccccc1</smiles>

69<smiles>[13CH3]CCCl</smiles>

72<smiles>CCCCCC</smiles>

67

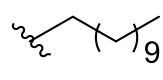

68<smiles>CCCc1ccccc1</smiles>

70<smiles>[14CH3]CCO</smiles>

73<smiles>[Y]CCCCCC(=O)O</smiles>

71<smiles>[13CH2]CC[13CH2]</smiles>

74

Scheme 12: The synthetic targets of Ben's project 58

This work represented the first example of a synthetic strategy that avoided the extensive use of protecting groups for the synthesis of DMJ and derivatives. With a total overall yield of $65 \%$ over four steps from D-fructose, the methodology succeeded in surpassing previous syntheses in efficiency.

\subsection{Research questions}

For this research project, the following research questions were proposed. First, can the methodology be applied to the synthesis of piperidine triols 30-33? And second, can the methodology be applied using different amine reagents?

\subsubsection{Significance}

The research within this thesis provides a significant contribution to the original methodology developed for the synthesis of DMJ and derivatives ${ }^{58}$ as it expands its applicability to pentoses to allow for the synthesis of piperidine triols. Furthermore, as the shortest route to date is five steps ${ }^{57}$ this methodology could provide a shorter route towards the synthesis of piperidine triols and 
derivatives. In addition, it is shown that despite extensive use of protecting groups in all total syntheses reported thus far, only a minimal use of protecting groups should be required to synthesise the piperidines triols.

\subsubsection{Comparison}

The greatest difference between this research and the preceding work done within our group is the difference in starting materials. Previous work was done on fructose, which in the open-chain form bears a ketone function. Pentoses such as D-xylose are aldoses, which means they have an aldehyde function in the open-chain form. This is a significant difference, as aldehydes are more reactive than ketones. This is due to an increased opportunity for nucleophilic attack on the carbonyl function owed to the reduced steric hindrance of aldehydes. This allows more opportunity for aldoses to form the more thermodynamically stable six-membered ring, which causes a loss of substrate.

\subsection{Methods}

\subsubsection{Retrosynthesis}

To apply the methodology to pentoses, the following retrosynthesis was applied (Scheme 13). Azasugar $\mathbf{7 5}$ was believed to be obtainable from an acidic hydrolysis of an iodo methyl pentoside 76 followed by reductive amination. The methyl iodopentoside can readily be obtained from the free pentose $\mathbf{7 7}$ using a Fischer glycosidation followed by regioselective iodination.

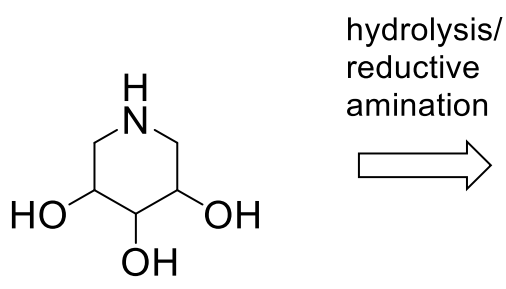

75

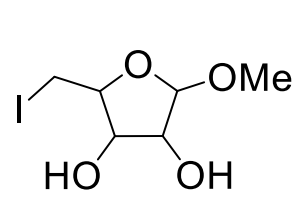

76

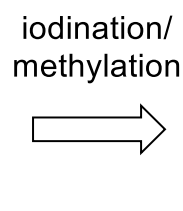<smiles>OCC1OC(O)C(O)C1O</smiles>

77

Scheme 13: Retrosynthetic analysis for the synthesis of piperidine triols from pentoses 


\subsubsection{Forward synthesis}

A four-step synthesis was proposed for the total synthesis of 30-33 (Scheme 14). From pentose 78, a Fischer glycosidation using $\mathrm{MeOH}$ under acidic conditions allows for the methyl protection of the anomeric centre to form the methyl pentoside 79. The methoxy group also functions to prevent ring-opening of the pentose, which ensures no side reactions occur on the open-chain structure. If water is present, the reaction can reverse to form the free pentose. Therefore, the reaction is neutralised once the equilibrium has been reached.

Next, the methyl glycoside will be iodinated under Garegg $^{60}$ conditions to obtain methyl iodopentoside 80 using $I_{2}$, imidazole and triphenylphosphine. The regioselectivity of this reaction occurs due to the primary hydroxyl group being more open to attack than the secondary hydroxyl groups. The iodine on the C-5 position provides a leaving group for the reductive amination to form a six-membered ring. Imidazole is also added to the reaction to accelerate the reaction and to counteract the acidity induced by the formation of hydrogen iodide during the reaction.

Because the 5-iodo pentose $\mathbf{8 1}$ is expected to be unstable due to rearrangement of the fivemembered ring to the six-membered ring, the acidic hydrolysis and reductive amination will be carried out as a one-pot procedure. However, acids can react with the reducing agent, which suggests that the acid concentration must be set with precision to avoid deactivation of the reductive amination. The acidic hydrolysis will be carried out in an aqueous acidic solution and without purification the ammonia and reducing agent will be added to perform the reductive amination to form azasugar 30. The order of addition is expected to be important since addition of the reducing agent could potentially reduce the aldehyde in the open-chain form of the pentose to a hydroxyl, which will irreversibly produce side-products. Lastly, hydrolysis and subsequent reductive amination reactions of a methyl 5-iodopentoside $\mathbf{8 0}$ would lead to the formation of the corresponding azasugar $\mathbf{3 0}$ in a one-pot two reaction procedure. 
(i) $\mathrm{AcCl}, \mathrm{MeOH}$,

$\mathrm{RT}, 22 \mathrm{~h}$<smiles>OC[C@H]1O[C@H](O)[C@@H](O)[C@@H]1O</smiles>

78<smiles>CO[C@H]1O[C@H](CO)[C@@H](O)[C@H]1O</smiles>

79<smiles>O[C@H]1CNC[C@@H](O)[C@@H]1O</smiles>

30
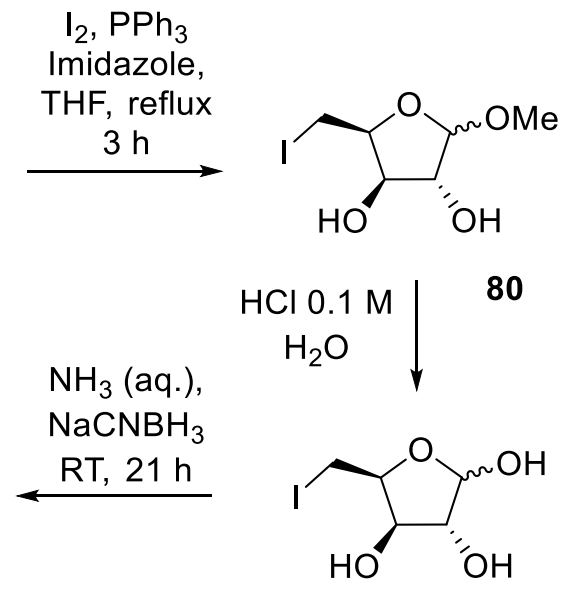

81

Scheme 14: Representative synthesis of a piperidine triol starting from D-xylose

This synthetic strategy was thought to be applicable to obtain all four diastereomers of piperidine triols. To achieve this, D-xylose (78), D-ribose (39), D-arabinose (82), and L-arabinose (83) were used as starting materials to produce the corresponding azasugars $\mathbf{3 0 - 3 3}$ (Figure 6). The methodology was further applied and developed to prepare a set of $N$-functionalised derivatives of the azasugars. The targeted derivatives included $N$-butyl analogues as this provides a lipophilic component to the polar body, which has previously led to increased biological activities. ${ }^{61}$ Another target was $N$-hydroxyethyl derivatives, as miglitol was found to have a significantly improved biological activity compared to its non-substituted analogue. ${ }^{41}$ Adding a handle for click chemistry may open up opportunities for an even wider variety of derivatisation to the azasugars. To this end, the $N$-propargyl derivatives of each piperidine triol were also to be prepared, which will allow for alkyne-related click chemistry. Lastly, $N$-phenylethyl derivatisation was attempted to challenge the scope of the methodology in applying bulky substituents.

The Fischer glycosidation and iodination reactions have both been reported for a variety of pentoses. ${ }^{62-64}$ As such, the first two reactions were expected to proceed with little issues and high yields. Since the hydrolysis and reductive amination reactions have not been carried out previously on D-xylose, D-ribose, D-arabinose and, L-arabinose, it was anticipated that any issues that may occur were most likely to do so during the hydrolysis and reductive amination steps. It is shown in the proposed mechanisms of the methyl deprotection and reductive amination steps, which are discussed in the next section, that most of the intermediates are open to side-reactions on, or by, the hydroxyl groups. 
<smiles>OC[C@H]1O[C@H](O)[C@@H](O)[C@H]1O</smiles>

78<smiles>OC[C@H]1O[C@H](O)[C@@H](O)[C@@H]1O</smiles>
D-ribose

39<smiles>OC[C@H]1O[C@H](O)[C@@H](O)[C@@H]1O</smiles>

D-arabinose

82<smiles>OC[C@H]1O[C@H](O)[C@@H](O)[C@@H]1O</smiles>

L-arabinose

83
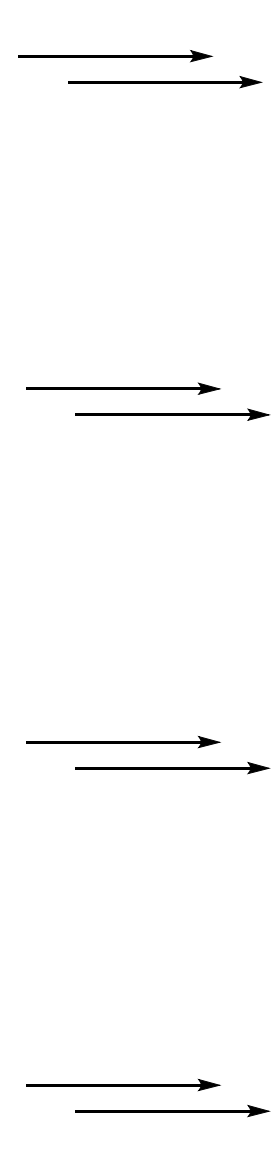

33

\section{$\mathrm{R}=\mathrm{H}, \mathrm{CH}_{2} \mathrm{CH}_{2} \mathrm{Ph}, \mathrm{Bu}$,}

$\mathrm{CH}_{2} \mathrm{CCH}, \mathrm{CH}_{2} \mathrm{CH}_{2} \mathrm{OH}$

Figure 6: A schematic overview of the proposed synthetic goals

In summary, a total of 20 piperidine triol targets were selected from an array of four different pentoses. The use of the methodology developed by Alex Hunt-Painter was expected to be applicable for the syntheses of the piperidine triol targets, although complications were initially expected to arise within the acidic hydrolysis and reductive amination step. 


\section{Results and discussion}

\subsection{Synthetic strategy}

\subsubsection{Iodination and Fischer glycosidation}

The synthetic strategy starts with a Fischer glycosidation of $\mathbf{7 7}$ to produce the methyl pentoside $\mathbf{8 7}$ (Scheme 15). Acidic conditions allow the anomeric hydroxy group of 84 to leave, upon which the anomeric position of $\mathbf{8 5}$ can be attacked by a methanol unit and subsequent deprotonation of $\mathbf{8 6}$ leads to the product $\mathbf{8 7}$. However, the reaction can potentially revert to form the original pentose if water is present, since the reaction is an equilibrium reaction.

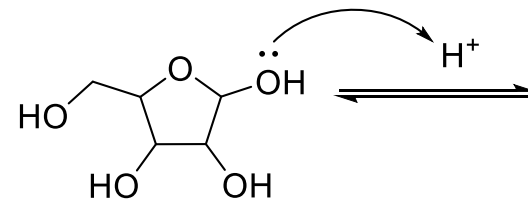

77<smiles>OCC1OC2(CCCC2)C(O)C1O</smiles>

84<smiles>COC1OC(CO)C(O)C1O</smiles>

87

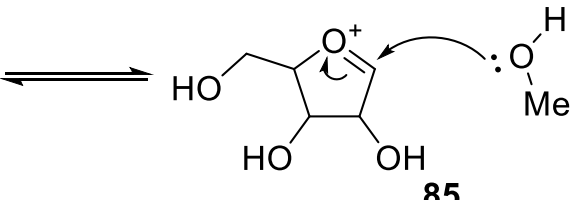

85

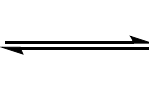

$\mathrm{HO}$<smiles>[13B]CCC[CH]C1OC(CO)C(O)C1O</smiles>

86

Scheme 15: The reaction mechanism of the Fischer glycosidation of the pentose starting material

Next, pentoside $\mathbf{8 7}$ is selectively iodinated on the C-5 position by means of an iodination under Garegg conditions (Scheme 16). This reaction is well known and has been applied for the conversion of primary alcohols to halides. ${ }^{65}$ Using triphenylphosphine and imidazole, the triphenylphosphine attacks the iodine and forms an electrophilic phosphonium salt, which is attacked by the primary alcohol. The presence of imidazole facilitates the formation of this phosphonium salt by acting as a scavenger of hydrogen iodide. ${ }^{60}$ The triphenylphosphine unit, now bound to oxygen in $\mathbf{8 8}$, can leave and form triphenylphosphine oxide. The iodide then leaves and attacks the open $\mathrm{C}-5$ position, forming the iodinated pentoside $\mathbf{7 6}$. 


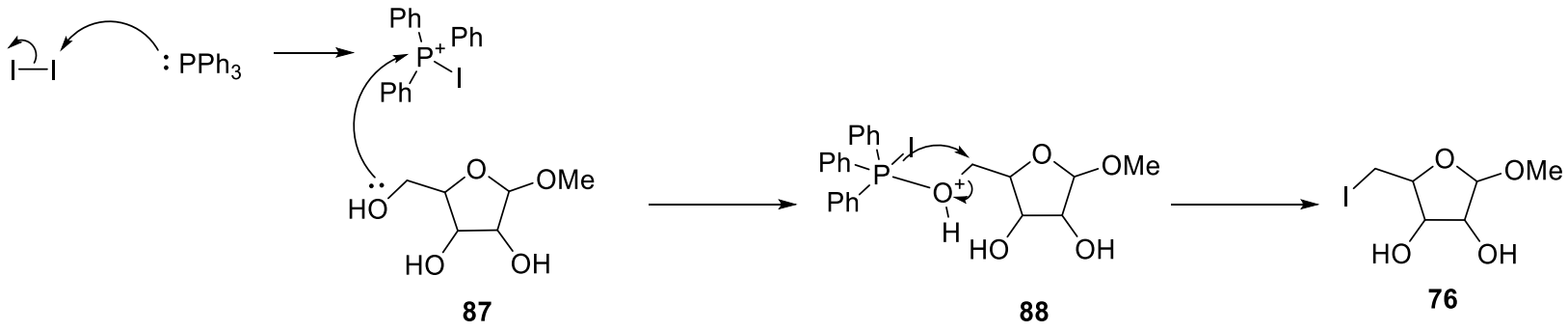

Scheme 16: The reaction mechanism of the iodination reaction of the methyl pentoside

\subsubsection{Reductive amination and hydrolysis}

Prior to the reductive amination, the methyl pentoside must undergo acidic hydrolysis to open the anomeric position (Scheme 17), which allows the pentose to revert to its open-chain aldehyde form. A potential problem arises during the hydrolysis reaction, as the resulting product could be unstable and may readily eliminate iodine to form the corresponding pyranose ring. To avoid this, the hydrolysis could be performed as a one-pot reaction with subsequent reductive amination. Because of this, careful consideration must be taken in the concentration of acid during the hydrolysis reaction. An abundance of acid would react with the reducing agent and prevent the final nonreversible step in the reductive amination to occur.

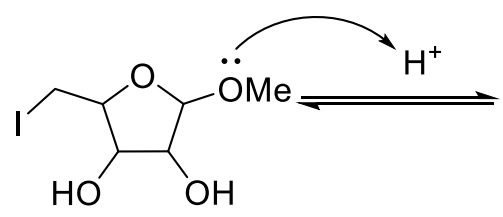

76<smiles>C=CCC1(O[O+](C)C)OC(CI)C(O)C1O</smiles>

89<smiles>OC1OC(CI)C(O)C1O</smiles>

92<smiles></smiles>

90<smiles>[B]CC[CH][OH+]C1OC(CI)C(O)C1O</smiles>

91

Scheme 17: The reaction mechanism of the hydrolysis of a 5-iodo methyl pentoside

In the proposed mechanism, pentose $\mathbf{9 2}$ is in equilibrium with its open-chain aldehyde form $\mathbf{9 3}$ upon acidic hydrolysis (Scheme 18), which can undergo nucleophilic attack by the amine to form 94. Rapid proton transfer then leads to the elimination of water and imine formation in $\mathbf{9 5 .}$ 
Subsequent nucleophilic attack at the C-5 position in $\mathbf{9 6}$ by the resulting imine displaces the iodine and forms a cyclic imine $\mathbf{9 7}$. The imine could then be reduced by sodium cyanoborohydride, giving the azasugar $\mathbf{7 5}$ as the final product. The reductive amination can be carried out using a variety of different amines, allowing for derivatisation without the incorporation of additional steps. ${ }^{57}$ This is a significant advantage the methodology provides over previous strategies where nitrogen atoms were introduced by sodium azide or $N$-bromoacetamide. ${ }^{51,56}$

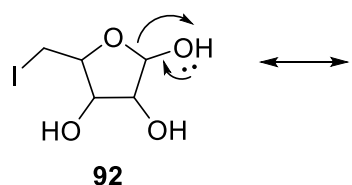

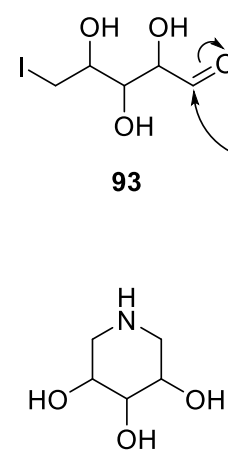

75<smiles>[NH3+]C([O-])C(O)C(O)CI</smiles>

94<smiles></smiles>

97

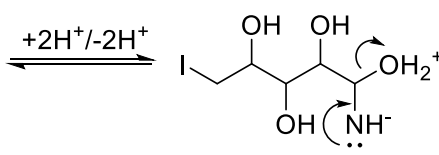

95
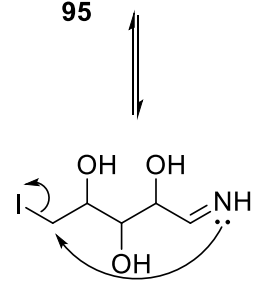

96

Scheme 18: Proposed mechanism for the reductive amination of a 5-iodo pentoside 


\subsection{D-xylose derived piperidine triols}

\subsubsection{The synthesis of $(3 R, 4 r, 5 S)$-piperidine triol from $\mathrm{D}$-xylose}

The first representative synthesis of a piperidine triol from a pentose commenced with the Fischer glycosidation of D-xylose (78, Scheme 19) to obtain methyl xyloside $\mathbf{7 9}$ in $94 \%$ yield. The product was characterised using 1D and 2D NMR experiments. The presence of a high intensity singlet at $3.39 \mathrm{ppm}$ indicted the formation of a methoxy group in the $\alpha$ configuration as in previous studies. ${ }^{66}$ The major product was identified to be in the furanose configuration by means of Heteronuclear Multiple Bond Correlation (HMBC) NMR analysis. A strong 3-bond correlation between C1 and H4 through the ring oxygen was observed, which can only be detected in the furanose form. In addition, no correlation is found between $\mathrm{C} 5$ and the anomeric protons, which further suggests that the main product is in the furanose form. Analysis by ${ }^{1} \mathrm{H}$ NMR spectroscopy also allowed for the identification of an additional doublet at $5.17 \mathrm{ppm}$ (Figure 7).<smiles>OC[C@H]1O[C@H](O)[C@@H](O)[C@@H]1O</smiles>

78

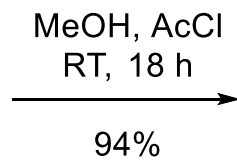

$94 \%$<smiles>CO[C@H]1O[C@H](CO)[C@@H](O)[C@H]1O</smiles>

79

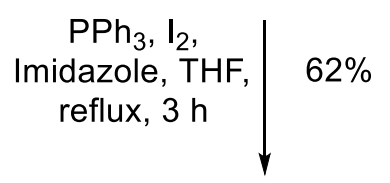<smiles>O[C@H]1CNC[C@@H](O)[C@H]1O</smiles>

30
1) $\mathrm{HCl}(0.1 \mathrm{M}$, aq.), reflux, $30 \mathrm{~m}$

2) $\mathrm{NH}_{3}$ (aq. $\left.28 \% \mathrm{w} / \mathrm{w}\right)$ $\mathrm{NaBH}_{3} \mathrm{CN}$, 19 h, RT

$77 \%$ (from 80 )<smiles>CO[C@H]1O[C@H](CI)[C@@H](O)[C@H]1O</smiles>

80

Scheme 19: The synthetic route towards the total synthesis of $(3 R, 4 r, 5 S)$-piperidine triol from $D$-xylose 


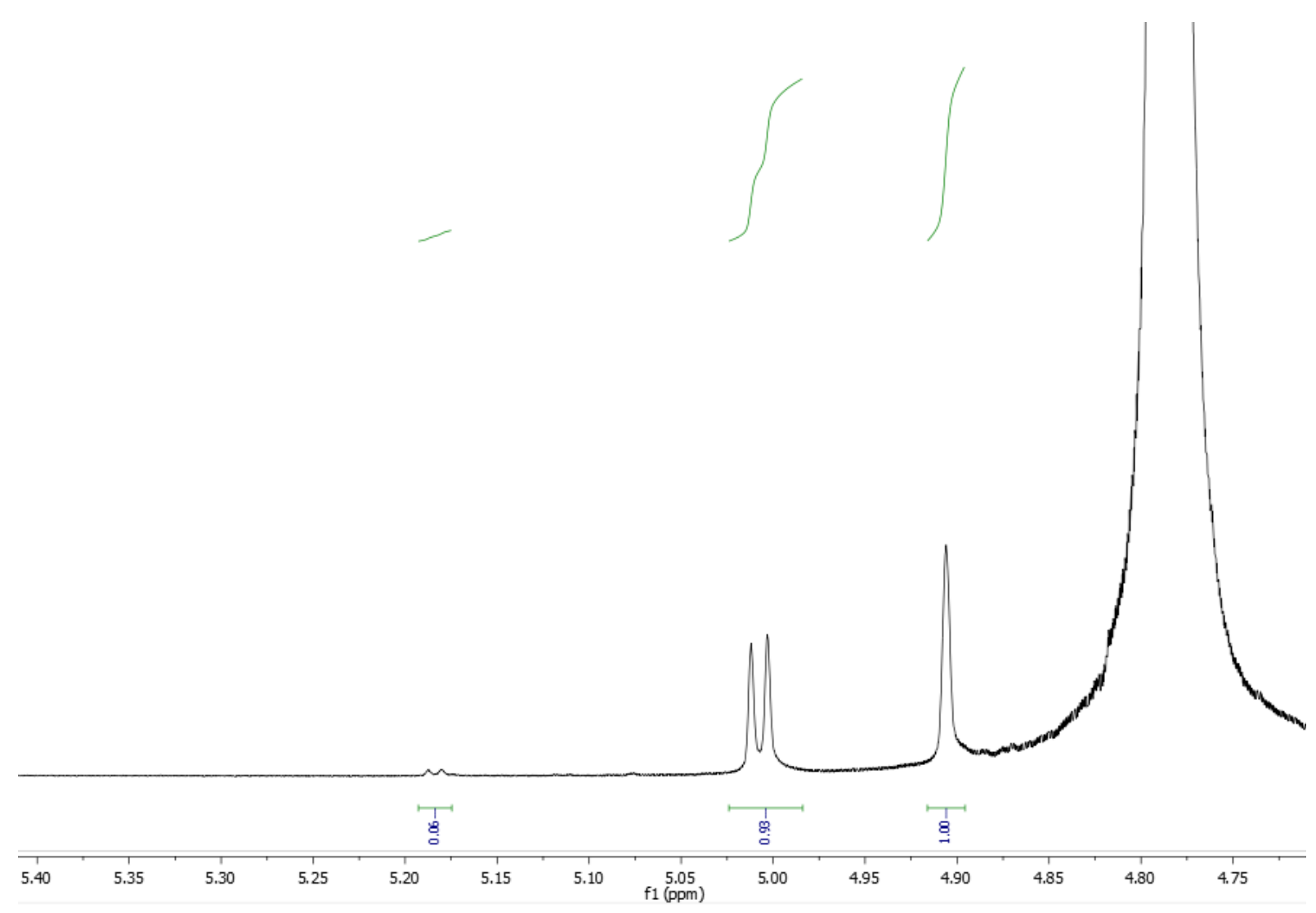

Figure 7: Detail of the ${ }^{1} \mathrm{H}-\mathrm{NMR}$ spectrum of methyl $\alpha, \beta-\mathrm{D}-x y l o f u r a n o s i d e$, showing the observed doublet at 5.17 ppm thought to belong to the pyranose by-product

This signal is thought to belong to the anomeric centre of the pyranose by-product due to its splitting pattern and the high chemical shift commonly observed in anomeric protons. However, the by-product was not produced in adequate quantities to obtain it in pure form for identification and therefore no definitive conclusion could be made. Subjecting the purified methyl furanoside to iodine and triphenylphosphine in the presence of imidazole as previously reported by Madsen $e t$ al. ${ }^{64}$ gave the methyl 5 -iodofuranoside 80 in $62 \%$ yield. Careful and controlled addition of the iodine was found to be essential, as swift addition of the iodine to the reaction readily allows for the reaction of iodine with moisture in the reaction mixture. Hydroiodic acid is formed as a byproduct and can catalyse the hydrolysis of the anomeric methoxy functionality by lowering the $\mathrm{pH}$, ultimately forming the previously discussed pyranose by-product observed in the Fischer glycosidation. Addition of iodine to the reaction mixture was found to be most efficient through dropwise addition of a solution of iodine in THF. This serves to provide the most controlled addition of the iodine such that the $\mathrm{pH}$ is not significantly altered before the imidazole can counteract the hydroiodic acid formed during the reaction. Although the reaction can be applied to both primary and secondary alcohols, only one product is formed over many different possible 
2-, or 3- mono or di-iodinated side products. This is because the reaction is reported to show higher preference to less sterically hindered hydroxyl functionalities due to the highly bulky and rigid structure of triphenylphosphonium iodide. ${ }^{67}$ This allows for a higher selectivity towards primary alcohols over secondary alcohols and thus primarily forms the desired mono 5-iodo substituted iodoglycoside. Characterisation of the desired product was done by 1D and 2D NMR experiments. The chemical shift of an alkyl halide carbon is shifted upfield towards 0-10 ppm due to the high deshielding effect of the iodine. Indeed, the ${ }^{13} \mathrm{C}-\mathrm{NMR}$ shifts for the $\mathrm{CH}_{2} \mathrm{I}$ functionalities of the $\beta$ and $\alpha$-methyl iodoxylosides were found at 1.8 and $1.5 \mathrm{ppm}$ respectively, which is consistent with previous studies ${ }^{68}$ and confirms the formation of the 5-iodo functionality in the major product. In addition, 3-bond correlations were found in the HMBC spectrum between the low shift carbons and $\mathrm{H}-3$ and H-4, further confirming that the iodine was successfully added at the C5-position. Having obtained methyl 5-iodoxyloside, the synthesis of $(3 R, 4 r, 5 S)$-piperidine triol was commenced by acidic hydrolysis of the methyl protecting group by use of $\mathrm{HCl}(0.1 \mathrm{M}$, aq.) at reflux for $30 \mathrm{~min}$ to form 5-deoxy-5-iodoxylose. It was found by TLC analysis that the anomer with the lower $\mathrm{R}_{f}$ value is deprotected more readily than the anomer with the higher $\mathrm{R}_{f}$ value. This is thought to be due to the difference in increased steric hindrance of the methoxy group with regards to the C5 protons of the $\alpha$-, and $\beta$-methyl glycosides (Scheme 20).

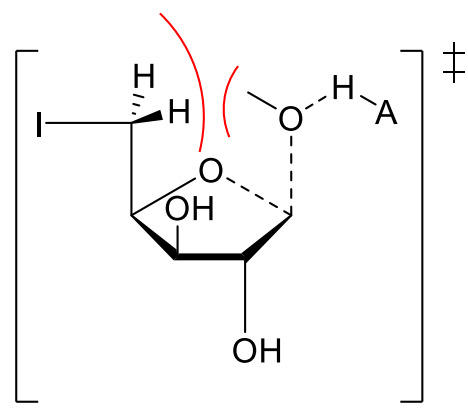

$\beta$-TS

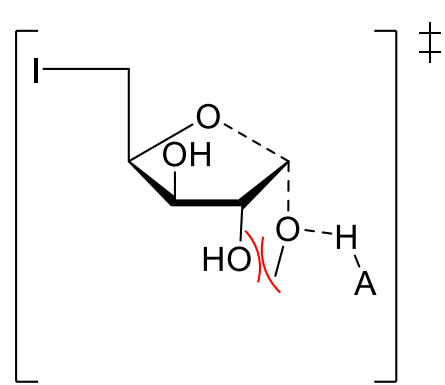

$\alpha-T S$

Scheme 20: Schematic representation of the steric strains observed in the $\beta$-iodoglycoside compared to the greater strain observed in the $\alpha$-glycoside during the acidic hydrolysis reaction. "A" represents an acid

While the $\beta$-anomer features 1,3-cyclic strain from the close proximity of $\mathrm{C} 5$ to the anomeric methoxy group ( $\beta$-TS), it is expected that the $\alpha$-anomer is experiences more steric strain from the 1,2 -cyclic interactions of the anomeric methoxy to the C2-hydroxy function ( $\alpha$-TS). Since the $\alpha$ anomer contains less steric influence from the $\mathrm{C} 5$ protons than the $\beta$-anomer, it is relieved of strain 
which drives the reaction and thus the hydrolysis reaction has a lower energy barrier compared to the $\beta$-anomer. Without the methoxyl group at the anomeric position, the iodofuranose was observed to degrade rapidly. Therefore, upon completion of the acidic hydrolysis, the reductive amination was followed immediately by the addition of ammonia (aq. 28\% w/w) and sodium cyanoborohydride, and stirred at room temperature for $19 \mathrm{~h}$. Addition of the amine before the reducing agent was found to be essential, as adding the reducing agent before the amine resulted in the formation of only one side product and no desired product. This by-product was observed during the first attempt of the synthesis of piperidine triol 30, wherein ammonia was added after the reducing agent. Identification by NMR and HRMS analysis $\left(m / z\right.$ calcd. For $\left[\mathrm{C}_{5} \mathrm{H}_{14} \mathrm{NO}_{4}\right]^{+}$: 152.0917, obsd.: 152.0904) revealed the by-product to be 1-amino-1-deoxy-D-xylitol 98 (Figure 8).

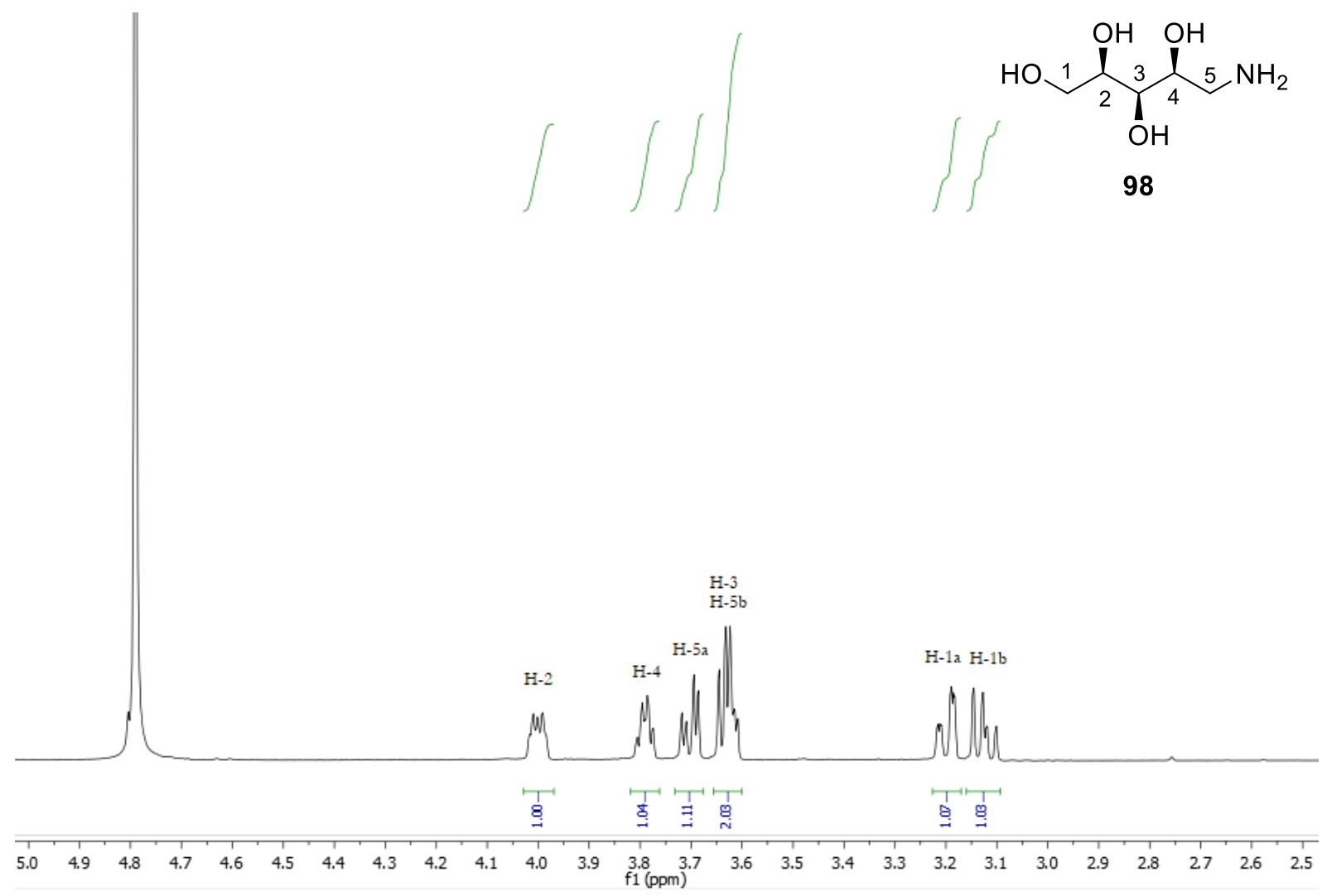

Figure 8: ${ }^{1} \mathrm{H}-\mathrm{NMR}$ spectrum of the major product of the first attempted synthesis of $(3 R, 4 r, 5 S)$-piperidine triol, observed to be 1-amino-1-deoxy-D-xylitol (98) 
The linear by-product is envisioned to form through the reduction of the aldehyde functionality of open-chain xyloside $\mathbf{9 9}$ by sodium cyanoborohydride to form iodinated xylitol (100, Scheme 21). The iodine functionality then readily undergoes nucleophilic attack by the amine to form xylitol $\mathbf{9 8}$.<smiles>OC1O[C@H](CI)[C@@H](O)[C@H]1O</smiles>

78

98

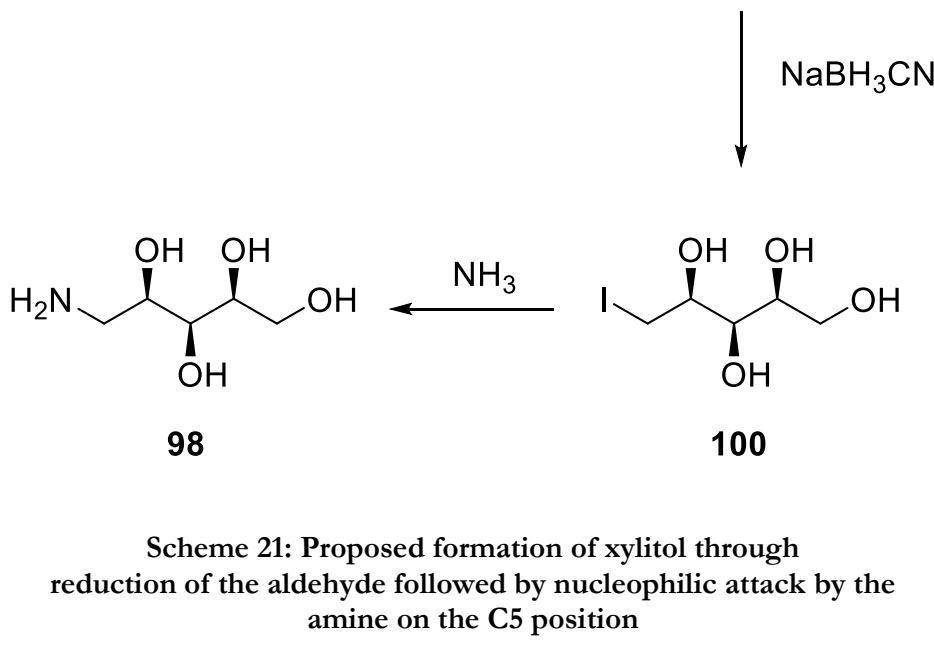<smiles>O=CC(O)C(O)C(O)CI</smiles>

99

The formation of this by-product was prevented by allowing enough time for the aldehyde function of the open-chain xyloside to undergo nucleophilic attack by the amine before addition of the reducing agent. Experiments indicate that there is no noticeable difference between immediate addition and 60 minutes of pause before addition of sodium cyanoborohydride, which suggests that the nucleophilic attack of the amine upon the aldehyde functionality proceeds rapidly even at ambient temperatures. By adding the amine before the reducing agent, $(3 R, 4 r, 5 S)$-piperidine triol 30 was obtained as a white solid in $77 \%$ yield after purification by silica flash column chromatography. The highest yielding route towards the synthesis of $(3 R, 4 r, 5 S)$-piperidine triol to date was published in 1990 by Ganem et al. ${ }^{48}$, achieving the synthesis in $40 \%$ overall yield from methyl 6-deoxy-6-bromo- $\alpha$-D-glucopyranoside over five steps. The methodology herein has surpassed the previously reported yield with an overall yield of $45 \%$ over four steps and is therefore the highest yielding and shortest route for the synthesis of $(3 R, 4 r, 5 S)$-piperidine triol to date. Extensive biological testing has shown that $(3 R, 4 r, 5 S)$-piperidine triol is a very potent inhibitor of glycosidases such as $\alpha$-xylosidase from $E$. coli with a $K_{i}$ value of $0.9 \mu \mathrm{M},{ }^{34} \alpha$-glucosidase from 
Saccharomyces cerevisiae with an $\mathrm{IC}_{50}$ value of $1.54 \mu \mathrm{M}$ and $\beta$-glucosidase from sweet almonds with an $\mathrm{IC}_{50}$ value of $0.51 \mu \mathrm{M}^{49}$

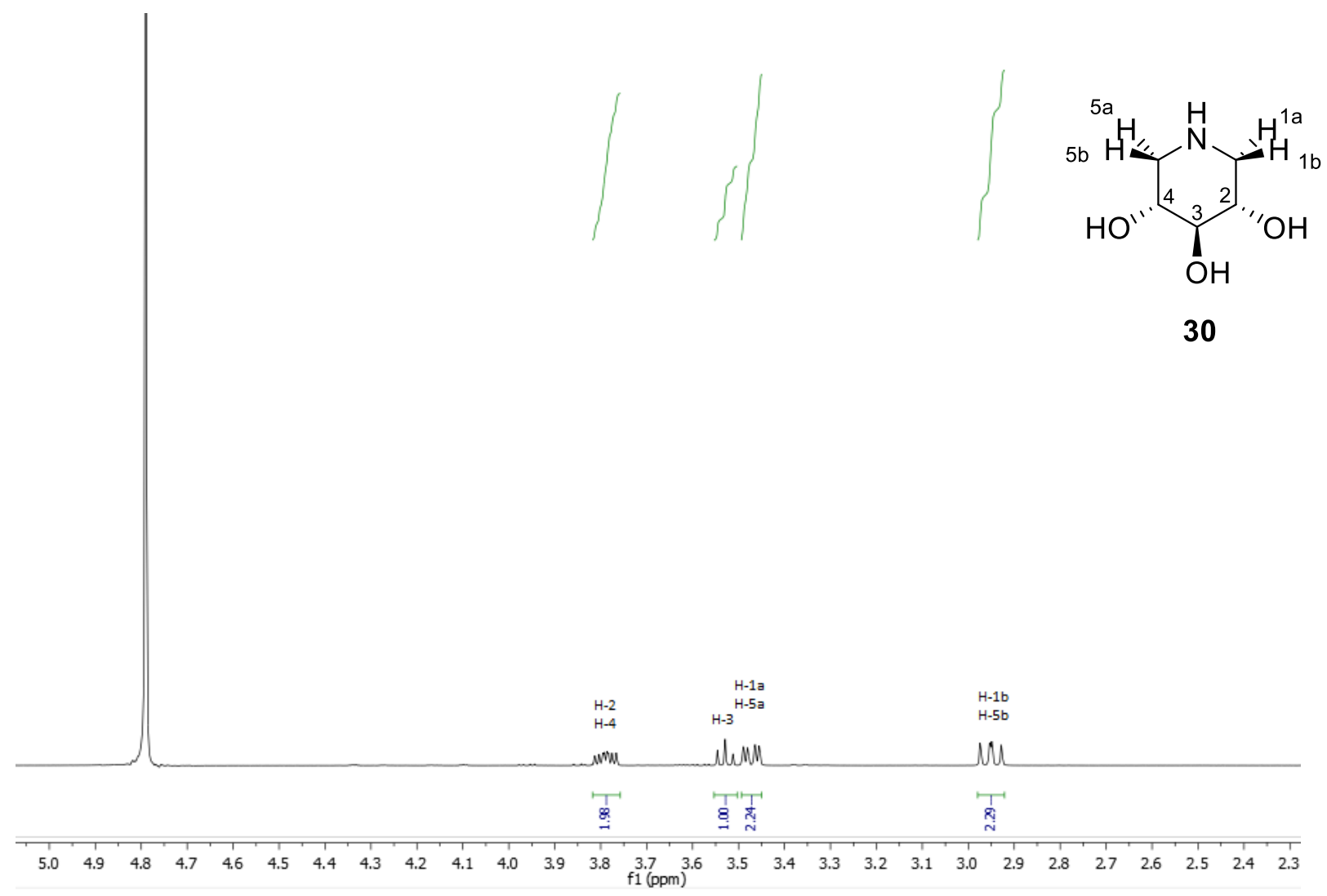

Figure 9: ${ }^{1} \mathrm{H}-\mathrm{NMR}$ spectrum of $(3 R, 4 r, 5 S)$-piperidine-3,4,5-triol (30)

Characterisation by NMR spectroscopy proved to be remarkably simple, as only four ring proton signals were observed, owing to the presence of a mirror plane (Figure 9). The lone triplet at 3.53 ppm couples to the ddd signal at $3.79 \mathrm{ppm}$, which further couples to both dd signals at 3.47 and $2.95 \mathrm{ppm}$. While it comes as no surprise that the signals from $\mathrm{H}-1 \mathrm{a}$ and $\mathrm{H}-1 \mathrm{~b}$ have different splitting patterns due to dihedral angles between $\mathrm{H}-1 \mathrm{a} / \mathrm{H}-2$ and $\mathrm{H}-1 \mathrm{~b} / \mathrm{H}-2$, the difference in chemical shift of approximately $0.6 \mathrm{ppm}$ between these peaks is more striking. A possible explanation can be formulated by considering the Newman projection of the $\mathrm{C} 2-\mathrm{C} 1$ or $\mathrm{C} 4-\mathrm{C} 5$ bond in piperidine triols (Figure 10). 


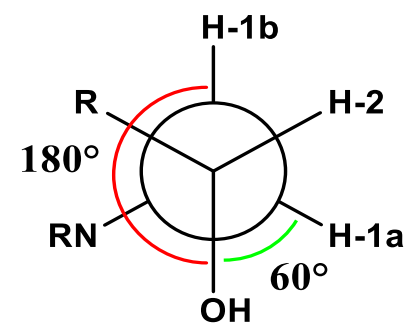

Figure 10: Newman projection of the $\mathrm{C} 2-\mathrm{C} 1$ or C4-C5 bond in $(3 R, 4 r, 5 S)$-piperidine triols

The axial-equatorial $60^{\circ}$ dihedral angle between proton $\mathrm{H}-1 \mathrm{a}$ and the $\mathrm{C} 2$ hydroxyl group forces the proton much closer to the hydroxy function than proton $\mathrm{H}-1 \mathrm{~b}$, which is separated by a trans-diaxial $180^{\circ}$ dihedral angle. The closer proximity of proton $\mathrm{H}-1$ a to the hydroxyl group results in a greater deshielding effect by the electronegativity of the oxygen and causes a higher downfield shift of protons $\mathrm{H}-1 \mathrm{a}$ and $\mathrm{H}-5 \mathrm{a}$ compared to $\mathrm{H}-1 \mathrm{~b}$ and $\mathrm{H}-5 \mathrm{~b}$.

\subsubsection{Expanding the library of $\mathrm{D}$-xylose derived piperidine triols}

Having successfully synthesised $(3 R, 4 r, 5 S)$-piperidine-3,4,5-triol, the next goal was to investigate the applicability of this methodology for the synthesis of D-xylose derived piperidine triols. To probe the viability of bulky amines within the methodology, benzylamine was utilised instead of ammonia (Scheme 22). Satisfyingly, the procedure afforded the pure $N$-benzyl azasugar 101 as a white solid in 39\% yield without any need for adaptations within the methodology. The most highyielding route towards the synthesis of azasugar 101 was reported by Shankar et al. in $1993,{ }^{69}$ having prepared the azasugar in an overall yield of $42 \%$ from isopropylidene protected D-glucofuranose in four steps. In this body of work, 101 was obtained in an overall yield of 23\% from D-xylose, which is significantly lower than previously reported. However, it is believed that an overall yield of $42 \%$ can be surpassed using this method. A yield of at least $72 \%$ is required to achieve a higher overall yield than reported previously, which is thought to be possible through rough estimation of the product peaks in the ${ }^{1} \mathrm{H}-\mathrm{NMR}$ spectrum of the crude reaction mixture before purification. Furthermore, compound $\mathbf{1 0 1}$ has yet be assayed for its ability to act as an inhibitor of glycosidases or glycosyl transerasess and its biological activity is still therefore unknown. Although a significantly lower yield compared to the synthesis of $(3 R, 4 r, 5 S)$-piperidine-3,4,5-triol was observed, it was attributed to the complication of purification. Azasugars such as the N-benzyl derivative of $(3 R, 4 r, 5 S)$-piperidine-3,4,5-triol are much less polar than the free azasugar due to the highly apolar aromatic ring, which results in $\mathrm{R}_{f}$ values close to that of sodium cyanoborohydride. 


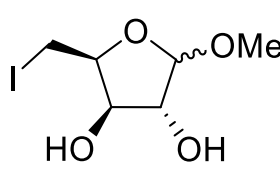

80

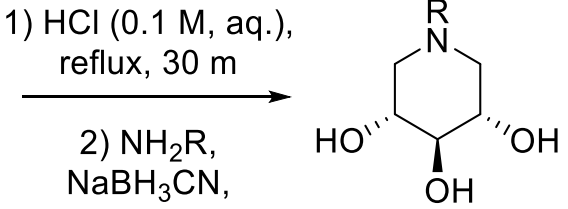

$19 \mathrm{~h}, \mathrm{RT}$

101: $\mathrm{R}=\mathrm{Bn}, 39 \%$

102: $\mathrm{R}=3 / 2 \sim \mathrm{Ph}, 47 \%$

103: $\mathrm{R}=-\left(\mathrm{CH}_{2}\right)_{3} \mathrm{CH}_{3}, 60 \%$

104: $R=3 / 2$

105: $\mathrm{R}=3 \mathrm{q}_{\mathrm{O}} \mathrm{OH}, 71 \%$

Scheme 22: The synthesis of $\mathbf{N}$-alkyl derivatives of $(3 R, 4 t, 5 S)$-piperidine-3,4,5-triol from D-xylose

With the successful synthesis of the N-benzyl azasugar derivative, an even bulkier amine was trialled in this methodology, making use of 2-phenylethylamine to further probe the scope of this synthetic route. Not needing to adapt the methodology, the $N$-phenylethyl azasugar derivative 102 was obtained as a white solid in $47 \%$ yield. This azasugar has not had studies reporting on its synthesis or biological activity. This body of work therefore represents the first example of the synthesis of this novel compound in a short and high yielding synthetic route. Having successfully utilised a bulky apolar amine in this reaction, the next goal was to prepare the $N$-butyl derivative. The interest in this particular $N$-alkyl derivative stems from the success of $N$-butyldeoxynojirimycin as a drug for the treatment of a lysosomal storage disease under the trade name Zavesca ${ }^{\circledR} .^{70}$ The use of $n$-butylamine in the methodology successfully led to the preparation of (3R,4r,5S)-1-butylpiperidine-3,4,5-triol (103) as a white solid in 55\% yield from methyl 5iodoxyloside. One other example of the synthesis of $\mathbf{1 0 3}$ has been reported previously. McCaig et al. ${ }^{71}$ prepared the $N$-butyl azasugar in 35\% overall yield over six steps starting from xylitol. While a near equal overall yield of $32 \%$ over four steps was achieved in this body of work, it is thought that a higher overall yield can be obtained through this route, as the methoxy deprotection and reductive amination steps only afforded 55\% yield. Improvements within the purification steps are thought to provide a higher yield and thus lead to a higher overall yield than what is reported for 103 within this thesis. Surprisingly, no biological studies have been reported for the N-butyl derivative, which makes it unclear whether the $N$-butyl derivatisation is of significance for this type 
of azasugar. Nevertheless, an $N$-propargyl azasugar derivative was selected as the next target in the series of $N$-alkyl piperidine triol analogues derived from D-xylose to put the methodology to test in terms of reactive amines and to obtain an appealing product due to the attractive alkyne handhold of the propargyl functionality for further reactions such as certain types of click chemistry. Thus, the synthesis of (3R,4r,5S)-1-propargylpiperidine-3,4,5-triol (104) was attempted by utilising propargylamine in the reductive amination step, which successfully afforded the desired product in a satisfying 60\% yield over two steps from methyl 5-iodoxyloside. $N$-propargyl derivative 104 has not had any studies reporting on its biological activity, nor on preparation. This body of work therefore represents the first example of the synthesis of this azasugar in a short and high yielding synthetic route. Lastly, an $N$-hydroxyethyl analogue is of interest due to the positive influence of the hydroxyethyl functionality upon $\alpha$-glucosidase inhibition in Miglitol. ${ }^{72}$ The use of ethanolamine in the methodology successfully afforded the $N$-hydroxyethyl azasugar analogue $\mathbf{1 0 5}$ in $71 \%$ yield over two steps from methyl 5-iodoxyloside. With the successful synthesis of the $N$ hydroxyethyl azasugar derivative, the series of piperidine triols was completed with limited issues and no need for adaptation within the original methodology.

Each azasugar product within this series was purified by silica flash column chromatography. Purification by Dowex $\left(\mathrm{H}^{+}\right)$ion exchange chromatography was found to result in significantly lower yields compared to purification efforts using silica. This may have occurred due to high affinities of the azasugars to the ion exchange resin, which causes the products to adhere too strongly to retrieve in full yield. The only exception was the $N$-propargyl derivative 104, which was obtained in high yield through purification by Dowex $\left(\mathrm{H}^{+}\right)$resin followed by flash column chromatography. However, NMR data of the product obtained from Dowex $\left(\mathrm{H}^{+}\right)$ion exchange purification showed an additional impurity peak as a high intensity singlet at $4.68 \mathrm{ppm}$ which only couples to itself as shown in 2D NMR experiments. HRMS analysis revealed a noticeable additional signal with an $m / z$ value of 141.1137 , which is in accordance to the exact mass of hexamethylenetetramine (106, Figure 11). 


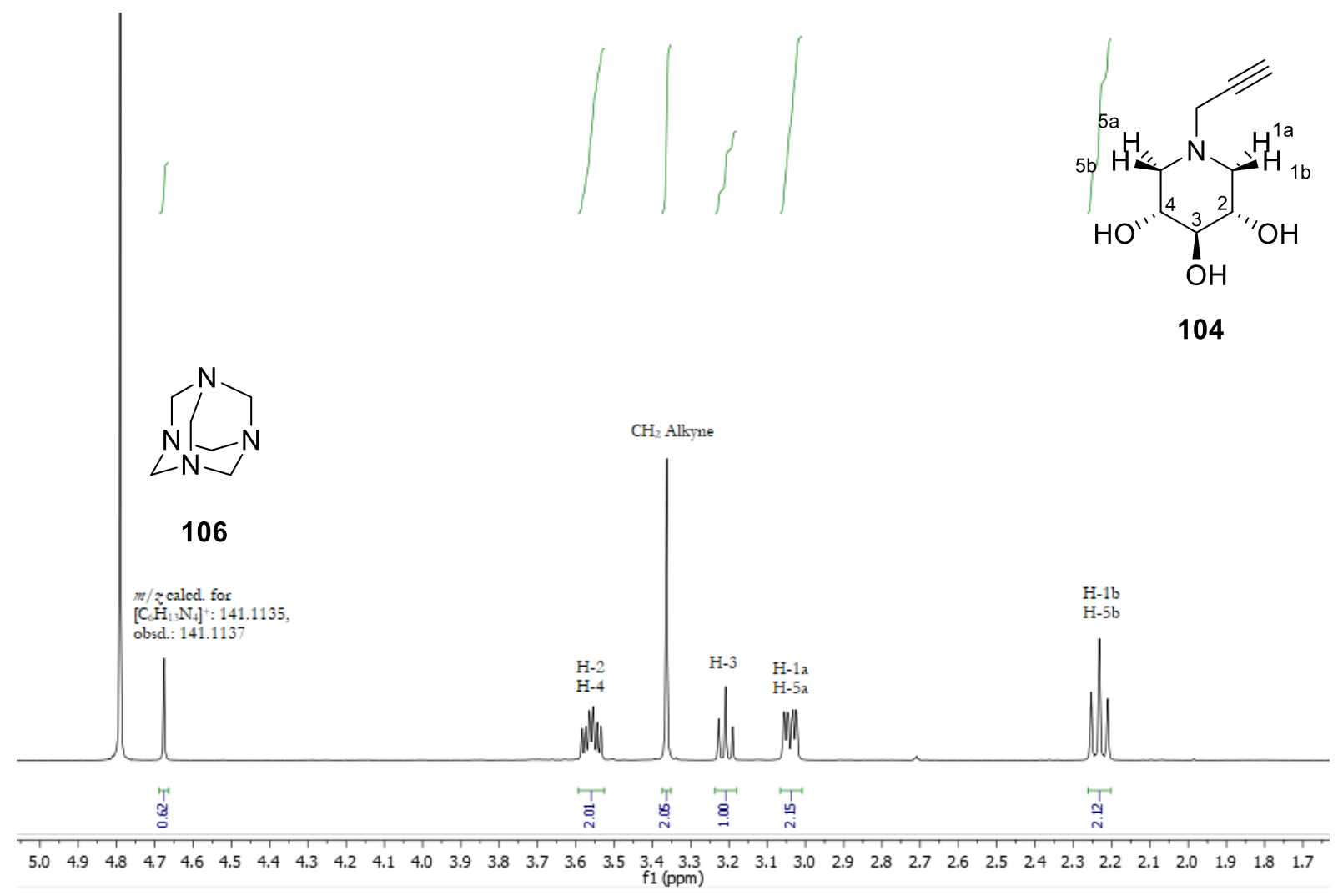

Figure 11: ${ }^{1} \mathrm{H}-\mathrm{NMR}$ spectrum of 105 , showing an additional singlet peak belonging hexamethylenetetramine at $4.68 \mathrm{ppm}$

It is envisioned that the formation of hexamethylenetetramine is mediated by high concentrations of ammonia in DCM, which allows the ammonia to displace the chlorine atoms of DCM to form methanediamine units, which then further react to form the adamantane-like structure. This impurity was not observed in any other reactions where use of Dowex $\left(\mathrm{H}^{+}\right)$ion exchange purification methods were not utilised, which presently seems to be the most feasible way to prevent the accumulation of this compound with the desired product. Another attempt to simplify purification efforts was made by co-evaporating the reaction after completion with a mixture of toluene/methanol/acetic acid $(1: 1: 1, \mathrm{v} / \mathrm{v} / \mathrm{v})$, which serves to convert the cyanoborohydride into the volatile trimethyl borate, which can be removed by evaporation. While this method was found to work well, it was generally observed that separation of the azasugar product from the reducing agent was feasible enough to omit the co-evaporation step. Similar to $(3 R, 4 r, 5 S)$-piperidine-3,4,5triol, the NMR characterisation for the $\mathrm{N}$-alkylated piperidine triols was feasible as all previously mentioned peaks were present with identical J-couplings and chemical shift values. Any additional peaks were always derived from the $N$-substituted functionality. Further confirmation was done by HMBC analysis, observing strong correlations between $\mathrm{C} 1, \mathrm{H}-5$ and $\mathrm{N}$-substituted functionalities (e.g., the methylene group found in $N$-benzyl derivative 101 ). 
Despite being a worse nucleophile, the use of ammonia in this methodology has generally led to notably higher yields than more nucleophilic secondary amines such as 2-phenylethylamine. A possible influencing factor is molecule size or steric hindrance, since 2-phenylethylamine or $n$ butylamine is a much more bulky amine than ammonia, which should allow for a much easier approach of the nucleophile to the electrophilic centre. However, the electrophilic centre is an aldehyde which already features great accessibility, leaving this suggestion plausible but unlikely to be the main cause. Instead, it is possible that this may be caused by the extreme excess of the highly concentrated ammonia added to the reactions, which helps to enforce the desired reaction pathway over other minor ones. Indeed, a major by-product (107) was observed in reaction using amines other than ammonia, being the most prevalent impurity in addition to being the toughest compound to separate from the desired product. The by-product was successfully isolated in high purity from the desired product during the synthesis of azasugar 102 (Figure 12).

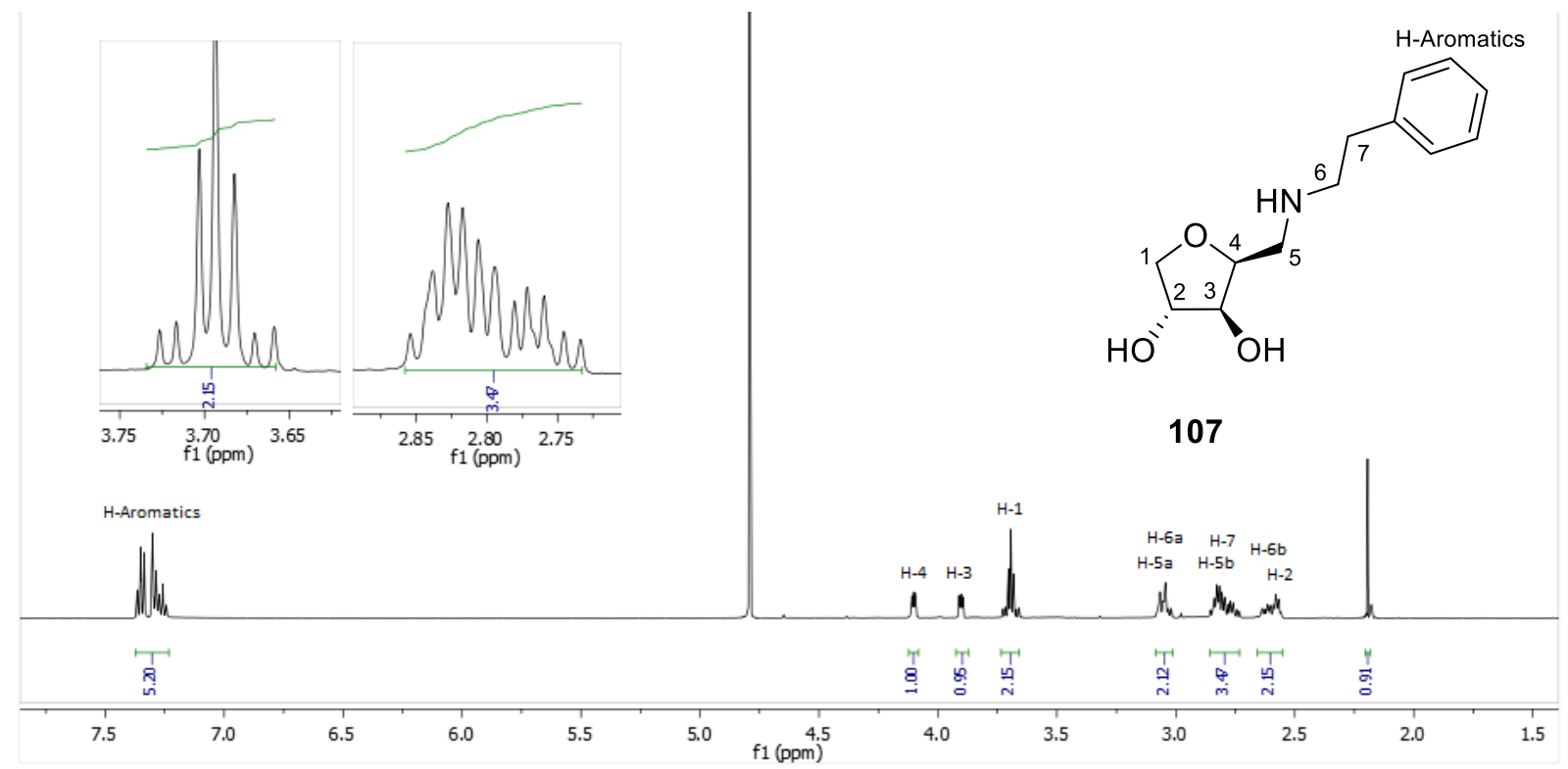

Figure 12: ${ }^{1} \mathrm{H}-\mathrm{NMR}$ spectrum of the by-product observed during the synthesis of $\mathrm{N}$-phenylethyl azasugar 102

The furanose by-product was identified by NMR spectroscopy and confirmed by HRMS analysis to have the same exact mass as the desired product. Formation of the by-product is envisioned to occur through an oxygen-mediated ring-closing mechanism (Scheme 23). 


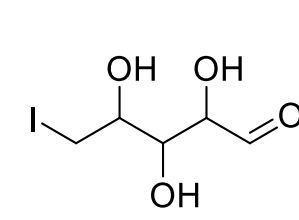

93

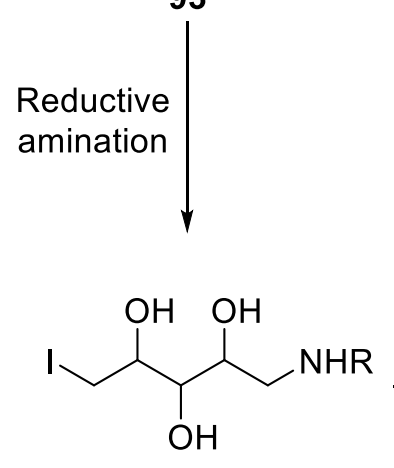

110

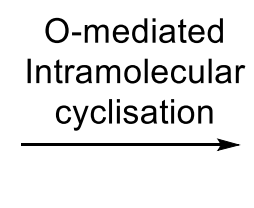

$\mathrm{HO}$

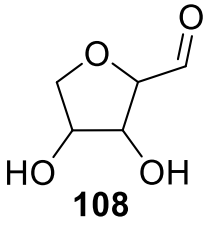

Reductive

amination

O-mediated

Intramolecular

cyclisation

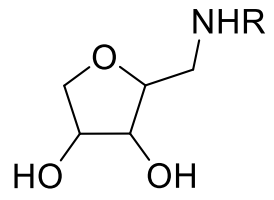

109

Scheme 23: Proposed route for the formation of the furanose by-product during the reductive amination step

The formation of the by-product is thought to be possible through either of two pathways. Omediated intramolecular cyclisation of the $\mathrm{C} 2$ hydroxy function to form the 2-formyl furanose 108, followed by reductive amination of the aldehyde functionality to form the by-product 109 . Alternatively, reductive amination could occur first to form the iodinated aminotriol 110, which can then undergo O-mediated intramolecular cyclisation as described previously to form byproduct 109, although no evidence has been found that supports one pathway over the other. For the reductive amination step to occur first, nucleophilic attack of the amine upon the aldehyde function must occur more readily than a 5 -membered ring formation through nucleophilic attack of an oxygen atom. Furthermore, the reducing agent would have to reduce the imine before either six-membered ring formation through the imine occurs, or oxygen-mediated five-membered ring formation. While the amine is thought to be more nucleophilic than the C2-hydroxy function and thus be more likely to attack the aldehyde function in the first step, it is unlikely that the reducing agent reduces the imine before 6-membered ring formation through nucleophilic attack of the imine upon the $\mathrm{C} 5$ position. If this were feasible, much lower yields and a higher by-product to product ratio would have expected to be observed in reactions utilising ammonia. Instead, it is believed to be more likely that furanose formation occurs through O-mediated intramolecular cyclisation, followed by reductive amination. Since the reductive amination step is done under basic conditions, the $\mathrm{C} 2$ hydroxy function can more easily form the furanose through intramolecular 
cyclisation, since it is more likely to be deprotonated than under acidic or neutral conditions. While the exact mechanism for the formation of this by-product is yet unclear, it was found that the relative ratio of product to by-product stayed consistent throughout the synthesis of each individual $N$-alkyl azasugar derivative. Little to no by-product was formed in the synthesis of $(3 R, 4 r, 5 S)$ piperidine triol, while by-product:product ratios were roughly estimated by NMR spectroscopy to be approximately 0.36:1 and 0.50:1 in the synthesis of 102 and 103 respectively. The by-product was also found to have an $\mathrm{R}_{f}$ value that is slightly higher than that of the product, and significantly complicates purification efforts due to its near-identical $\mathrm{R}_{f}$ value. The difficulty of isolating the product from the by-product is therefore suggested to be the main loss of yield throughout the synthesis of $\mathrm{N}$-alkylated piperidine triols.

Since the by-product was much less prevalent in reactions using ammonia, it was first envisioned that attempting to recreate these conditions within $N$-alkyl derivative syntheses by increasing the amine concentration in the reductive amination step should suppress the formation of by-product. The increased concentration of amine was also thought to help promote the intermolecular nucleophilic attack of the amine over the intramolecular cyclisation that forms the by-product. NMR analysis of the crude reaction mixture revealed that this adaptation had no significant effect on the formation of by-product. Next, it was considered that the formation of by-product may be kinetically or thermodynamically controlled and thus may be altered by adjusting the temperature of the reductive amination. The ${ }^{1} \mathrm{H}-\mathrm{NMR}$ spectrum of the crude reductive amination set at $0{ }^{\circ} \mathrm{C}$ contained more noise on the baseline, which suggests that the lower temperature slowed down the desired reaction, allowing other more kinetically favoured reactions to proceed instead. Performing the reductive amination at $100{ }^{\circ} \mathrm{C}$ was shown to be highly detrimental, as a significant increase in side reactions was observed which obscured the product in both TLC and NMR analysis.

Next, the suggested mechanism for the formation of the by-product was considered. The first step was believed to have been the O-mediated intramolecular ring-closure, which is facilitated by increasingly more basic conditions. In the standard conditions of the methodology, 3.0 equivalents of amine are added to the acidic reaction after the anomeric methoxy deprotection step, which raises the $\mathrm{pH}$ to approx. 9-10. In an attempt to lower the resulting $\mathrm{pH}$ during the reductive amination step, the reductive amination was performed using 1.5 or 2.0 equivalents of amine. However, NMR analysis yet again showed no significant reduction in by-product formation. With further regards to the suggested mechanism for the formation of by-product, it was envisioned that the amine may react with the substrate at mild acidic conditions of $\mathrm{pH}=5-6$ since imine formation is generally most favourable at $\mathrm{pH}=5$. This would then prevent the $\mathrm{C} 2$ hydroxy function from 
displacing the iodine before the nucleophilic attack of the amine could take place. Thus, reductive aminations were carried out using 1.1 and separately 2.0 equivalents of amine under mildly acidic $(\mathrm{pH}=5-6)$ or basic $(\mathrm{pH}=8$ or 12$)$ conditions. It was found that even mildly acidic conditions result in the amino xylitol side product 98 described in section 2.2.1, and basic conditions of $\mathrm{pH}=$ 8 and 12 had no observable impact on the formation of the furanose by-product.

A different approach was then considered, focusing on reaction concentrations rather than $\mathrm{pH}$. Since the initial $\mathrm{HCl}$ solution used for the methoxy deprotection step embodies the majority of volume in the reductive amination, it was suggested that reducing the initial amount of $\mathrm{HCl}$ solution would concentrate the reductive amination and thus favour the intermolecular nucleophilic attack of the amine over the intramolecular O-mediated ring-closing reaction. Mock reactions using 7.5 and $5.0 \mathrm{ml} / \mathrm{mmol}$ instead of $10 \mathrm{ml} / \mathrm{mmol} \mathrm{HCl}$ (aq. $0.1 \mathrm{M}$ ) for the anomeric deprotection step were performed. These reactions featured lower amounts of amine at 1.1 and 2.0 equivalents, as it was still believed that highly basic conditions would favour the formation of by-product. It was found that reduction of the concentration of initial $\mathrm{HCl}$ solution did not impact the formation of byproduct, regardless of amine concentrations ranging from 1.1 to 8 equivalents.

Next, an attempt was made to form the imine under mildly acidic conditions and to raise the $\mathrm{pH}$ before addition of the reducing agent. A small amount of $\mathrm{AcOH}(80 \mu \mathrm{l})$ was added prior to the addition of amine which prevented the $\mathrm{pH}$ from rising above 6 . Allowing the amine to react for 1 $\mathrm{h}$ under mildly acidic conditions, followed by addition of sodium cyanoborohydride after raising the $\mathrm{pH}$ to 9 using $\mathrm{NEt}_{3}$ showed formation of similar amounts of by-product in the crude ${ }^{1} \mathrm{H}-\mathrm{NMR}$ spectrum. Subsequent attempts using higher equivalents of amine indicated that amine concentrations of lower than 3 equivalents are detrimental to the reaction, as the ${ }^{1} \mathrm{H}-\mathrm{NMR}$ spectrum of the crude reaction containing 2.0 and 1.5 equivalents of amine contained much more side products. Raising the $\mathrm{pH}$ using $\mathrm{NaOH}$ instead of $\mathrm{NEt}_{3}$ allowed the $\mathrm{pH}$ to be raised to 14 , but this resulted in a significant increase in by-product formation. This confirms that by-product formation proceeds more readily under strongly basic conditions. Varying the $\mathrm{pH}$ of the imine formation step between 3-5 also did not positively affect the reaction outcome. Next, different buffer systems were trialled for the methodology in an attempt to catalyse the desired reaction over the by-product formation (Table 1). 
Table 1: Schematic overview of the entries in the mock reactions varying $\mathrm{pH}$ and buffer systems

\begin{tabular}{ccccc}
\hline Entry & Acid & Base & $\begin{array}{c}\mathrm{pH} \text { (imine } \\
\text { formation) }\end{array}$ & $\begin{array}{c}\mathrm{pH} \\
\text { (reduction) }\end{array}$ \\
\hline 1 & $\mathrm{AcOH}$ & $\mathrm{NaOAc}$ & 5 & 7 \\
2 & $\mathrm{AcOH}$ & $\mathrm{NaOAc} /$ & 5 & 8 \\
3 & $\mathrm{NaOH}$ & $\mathrm{NaOH}$ & 5 & 9 \\
4 & $\mathrm{HCl}$ & $\mathrm{NaOH}$ & 5 & 7 \\
5 & $\mathrm{HCl}$ & $\mathrm{NaOH}$ & 5 & 8 \\
\hline
\end{tabular}

The crude reaction mixture of entries 1 and 2 featured only small amounts of product, as indicated by their ${ }^{1} \mathrm{H}-\mathrm{NMR}$ spectra. Entry 3 was more successful than entries 1 and 2, but was still less successful than the original synthesis, showing a messier baseline in the crude ${ }^{1} \mathrm{H}-\mathrm{NMR}$ spectrum. Two additional attempts were made to carefully adjust the $\mathrm{pH}$ of the imine formation and the reduction step using $\mathrm{HCl}$ and $\mathrm{NaOH}$. Desired product formation was observed in the ${ }^{1} \mathrm{H}-\mathrm{NMR}$ of the crude reactions of entries 4 and 5, but many additional peaks were also present.

It was then proposed that addition of the amine at the start of the deprotection step may pre-empt the formation of the by-product by allowing it to immediately react with the resulting aldehyde in the open-chain form of iodo-xylose. Thus, 3 equivalents of amine were added to the reaction mixture of methyl 5-iodoxyloside in $\mathrm{HCl}$ (aq. $0.4 \mathrm{M}$ ) and the reaction went to completion after 15 minutes at reflux. The $\mathrm{pH}$ was then raised to $10 \mathrm{using} \mathrm{NaOH}$ and reacted for $19 \mathrm{~h}$ overnight. NMR analysis showed that by-product was still present in a 0.6:1 ratio of by-product to product. A final attempt to prevent the furanose formation was made by substituting the iodine on the 5 -position with the amine. This would prevent the by-product from forming by eliminating the main reactive centre in its mechanism, allowing the amine to react with the aldehyde function in the open-chain form, establishing the 6-membered ring and allowing reduction to form the desired azasugar product. Initial attempts to substitute the iodine with the amine by dissolving the methyl iodoglycoside in the amine proved successful, but slow. At ambient temperature under NEAT 
conditions the amine displaces the iodine and proceeds to near completion after 8 days, though heating to approximately $90{ }^{\circ} \mathrm{C}$ allowed the substitution reaction to reach full consumption of starting material after 4 days. However, purification efforts were still unrefined, leading to a $7.3 \%$ yield of substitution product.

Due to time constraints, no additional efforts were made. It is believed that optimising the substitution reaction of the iodine for the amine should allow for high yields of the methyl 5aminoglycoside. The next steps in the synthesis of the azasugar from the aminoglycoside would be the deprotection of the anomeric methyl group, followed by basification and subsequent reduction using sodium cyanoborohydride. Since this is a novel route, it is expected that some issues may occur during these steps, but it is thought to be possible and is thought to potentially result in a higher yield than the original methodology employed in this body of work may afford. 


\subsection{D-ribose derived piperidine triols}

Having successfully synthesised (3R,4r,5S)-piperidine triol and $N$-alkyl analogues from D-xylose, the next goal was to further expand the methodology by attempting the synthesis of piperidine triols from other substrates. The synthesis of $(3 R, 4 s, 5 S)$-piperidine-3,4,5-triol (31) commenced analogous to the previously described D-xylose derived piperidine triol (Scheme 24), subjecting Dribose to a Fischer glycosidation to obtain methyl riboside $\mathbf{1 1 1}$ in 69\% yield. Characterisation of the product was done using $1 \mathrm{D}$ and $2 \mathrm{D}$ NMR experiments. The presence of a high intensity singlet at $3.39 \mathrm{ppm}$ indicted the formation of a methoxy group in the $\beta$ configuration as in previous studies. ${ }^{73}$ Subsequent reaction of methyl riboside $\mathbf{1 1 1}$ with iodine and triphenylphosphine in the presence of imidazole afforded methyl 5-iodoriboside $\mathbf{1 1 2}$ in 65\% yield. Characterisation was done by NMR spectroscopy and the presence of an upfield signal constituting for the alkyl iodide carbon of the $\beta$-anomer at $7.4 \mathrm{ppm}$ was consistent with literature reports. ${ }^{63}$ Satisfyingly, the acid mediated hydrolysis of the methoxy protecting group of methyl 5-iodoriboside was found to be as feasible as for the xylose stereoisomer, reaching full consumption of starting material in $30 \mathrm{~min}$. Addition of ammonia and sodium cyanoborohydride at room temperature for $19 \mathrm{~h}$ and purification by silica flash column chromatography gave the pure (3R,4s,5S)-piperidine triol (31) in 89\% over two steps from methyl 5 -iodoriboside. The most recent synthesis of $(3 \mathrm{R}, 4 s, 5 S)$-piperidine triol was reported in 2016 by Martin et al., ${ }^{57}$ having prepared the azasugar starting from D-ribose in an overall yield of $24 \%$ over four steps. By achieving the synthesis in a total yield of $40 \%$ over four steps, this methodology has afforded a vast improvement and is the most high yielding route to date for the synthesis of $(3 R, 4 s, 5 S)$-piperidine triol. This azasugar has also undergone extensive biological testing and was found to be a potent inhibitor of $\alpha$-mannosidase from jack beans with an $\mathrm{IC}_{50}$ value of $1.88 \mu \mathrm{M},{ }^{49} \alpha$-glucosidase from Saccharomyces cerevisiae with an $\mathrm{IC}_{50}$ value of $3.70 \mu \mathrm{M}^{49}$ and $\beta$ glucosidase from almonds with an $\mathrm{IC}_{50}$ value of $8.8 \mu \mathrm{M}^{74}$ 
<smiles>OC[C@H]1O[C@H](O)[C@@H](O)[C@@H]1O</smiles>

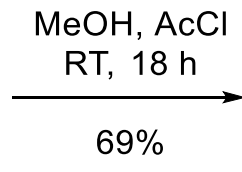<smiles>CO[C@H]1O[C@H](CO)[C@@H](O)[C@H]1O</smiles>

111

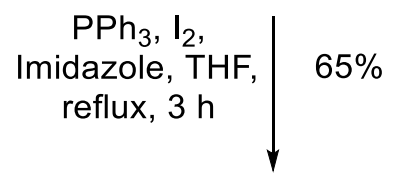<smiles>O[C@H]1CNC[C@@H](O)[C@@H]1O</smiles>

31
1) $\mathrm{HCl}(0.1 \mathrm{M}$, aq. $)$, reflux, $30 \mathrm{~m}$

2) $\mathrm{NH}_{3}$ (aq. $28 \% \mathrm{w} / \mathrm{w}$ ) $\mathrm{NaBH}_{3} \mathrm{CN}$, $19 \mathrm{~h}, \mathrm{RT}$<smiles>CO[C@H]1O[C@H](CI)[C@@H](O)[C@H]1O</smiles>

112

$89 \%$ (from 112)

Scheme 24: The synthesis of $(3 R, 4 s, 5 S)$-piperidine triol from D-ribose

With the successful synthesis of $(3 R, 4 s, 5 S)$-piperidine-3,4,5-triol, the next aim was to complete the series of piperidine triols derived from D-ribose (Scheme 25). Utilising 2-phenylethylamine, $n$ butylamine, propargylamine and ethanolamine within the methodology afforded their respective $N$-alkyl azasugars $(113,45,114,115)$ in high yields without any need for deviation within the methodology. The $N$-phenylethyl, $N$-propargyl and $N$-hydroxyethyl azasugar derivatives have not had studies reporting on their biological activity, nor on preparation. This body of work therefore represents the first example of the synthesis of these novel azasugars in a short and high yielding synthetic route. Only one other synthesis of $(3 R, 4 s, 5 S)$-1-butylpiperidine-3,4,5-triol has been reported previously. In a study by Ichikawa et al., ${ }^{51}$ an extensive route starting from D-ribose gave the $N$-butyl azasugar 45 in 18\% overall yield over seven steps. A great improvement was afforded following the methodology described in this thesis, which allowed for the shortest and highest yielding synthesis of $(3 R, 4 s, 5 S)$-1-butylpiperidine-3,4,5-triol to date from D-ribose in $28 \%$ overall yield over four steps. This analogue was found to be a moderate inhibitor of specifically $\beta$ galactosidase from Aspergillus orizae. ${ }^{74}$ However, the azasugar has had very limited attention, as there is currently only one study describing its biological activities, ${ }^{74}$ which leaves a question as to whether this azasugar has any biological relevance. 
<smiles>CO[C@H]1O[C@H](CI)[C@@H](O)[C@H]1O</smiles>

112
1) $\mathrm{HCl}(0.1 \mathrm{M}$, aq. $)$, reflux, $30 \mathrm{~m}$

2) $\mathrm{NH}_{2} \mathrm{R}$, $\mathrm{NaBH}_{3} \mathrm{CN}$, $19 \mathrm{~h}, \mathrm{RT}$<smiles>[R]C1C[C@@H](O)C(O)[C@H](O)C1</smiles>

113: $\mathrm{R}=3$ 红 $\mathrm{Ph}, 67 \%$

45: $\mathrm{R}=-\left(\mathrm{CH}_{2}\right)_{3} \mathrm{CH}_{3}, 62 \%$

114: $R=3 / 2$

115: $\mathrm{R}=32 \mathrm{OH}, 72 \%$

Scheme 25: The synthesis of $\mathbf{N}$-alkyl derivatives from D-ribose

All azasugars were purified using only flash column chromatography and were obtained in high purity. As expected, characterisation by NMR spectroscopy was found to be just as simple as for D-xylose derived piperidine triols, since both types of azasugars share a vertical plane of symmetry. However, for each of the D-ribose derived piperidine triols it was found that some of the peaks in the ${ }^{1} \mathrm{H}-\mathrm{NMR}$ spectrum were unusually broad (Figure 13).

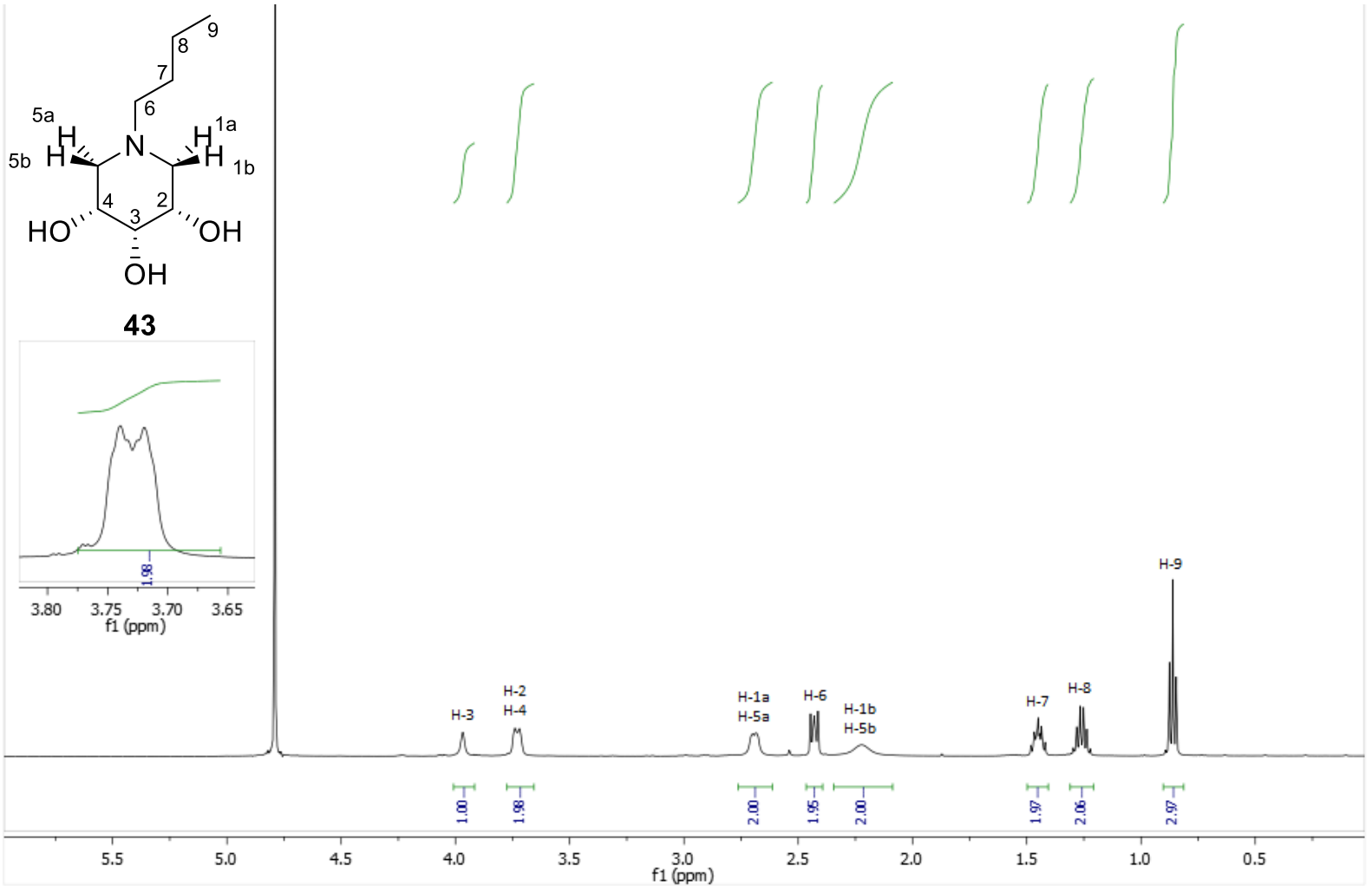

Figure 13: ${ }^{1} \mathrm{H}-\mathrm{NMR}$ spectrum of azasugar $(3 R, 4 s, 5 S)$-1-butylpiperidine-3,4,5-triol (45), showing the typical peaks related to $\mathrm{D}$-ribose derived piperidine triols 
Furthermore, the H-3 proton peak at 3.97 ppm features a significant shift compared to the shift previously observed for the H-3 proton peak seen at approx. $3.50 \mathrm{ppm}$ in D-xylose derived azasugars. This is likely due to the same phenomenon that causes the shift of protons $\mathrm{H}-1 \mathrm{a}$ and $\mathrm{H}$ $5 \mathrm{a}$ compared to $\mathrm{H}-1 \mathrm{~b}$ and $\mathrm{H}-5 \mathrm{~b}$ as discussed previously. The exact reason for the broadening of signals is yet unclear, although a possibility is that the compounds do not have a clear preference for one particular chair conformation, and undergo rapid interconversion between the ${ }^{1} \mathrm{C}_{4}$ and ${ }^{4} \mathrm{C}_{1}$ chair conformations.

Similar to the purification of D-xylose derived piperidine triols, it was found that purification by Dowex $\left(\mathrm{H}^{+}\right)$ion exchange resin led to a decrease in yield compared to purification by silica flash column chromatography. However, it was surprising to find that the yields obtained from the reductive aminations of methyl 5-iodoriboside were notably higher than those of methyl 5iodoxyloside. Indeed, the ${ }^{1} \mathrm{H}-\mathrm{NMR}$ spectrum of the crude reaction mixture showed no clear presence of any by-product whatsoever during the synthesis of $\mathbf{1 1 3}$. While the yield of this specific reaction was found to be only $67 \%$, the purification method for these compounds in general is still unrefined and can significantly increase the yield with further development. It is yet unknown why the furanose by-product does not form during the synthesis of D-ribose derived piperidine triols but readily forms during the synthesis of D-xylose derived piperidine triols. One possibility is that the steric interactions between the hydroxy function on the C3 and C4 positions are more favourable in the proposed transition state from D-xylose compared to that of D-ribose (Scheme 26).

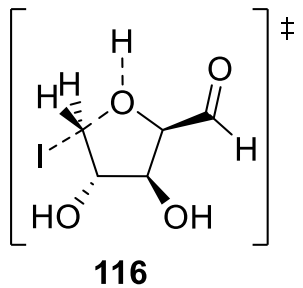

116

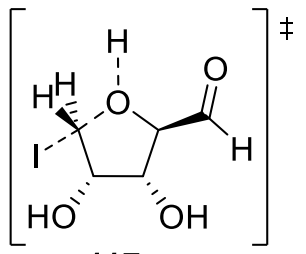

117

\footnotetext{
Scheme 26: A proposed theory for the formation of furanose by-product in $\mathrm{D}$-xylose derived piperidine triols in contrast to the lack thereof in the preparation of D-ribose derived piperidine triols
}

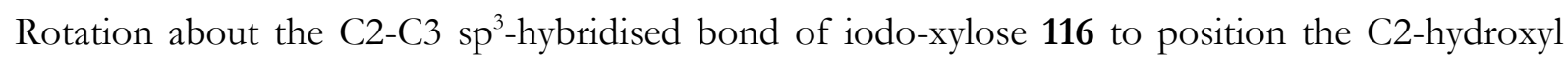
group for nucleophilic attack upon the $\mathrm{C} 5$ position and sets the compound in a C3-C4 trans configuration 116 which is more favourable than the $\mathrm{C} 3-\mathrm{C} 4$ cis relation featured in the ribose 
isomer 117 It is therefore possible that the more favourable transition state $\mathbf{1 1 6}$ features a sufficiently lowered energy barrier for the O-mediated intramolecular cyclisation of iodo-xylose prior to the addition of the amine. Conversely, the unfavourable transition state $\mathbf{1 1 7}$ is expected to have a higher energy barrier, which may be sufficient to disallow the formation of the furanose byproduct prior to and after nucleophilic attack of the amine upon the aldehyde function.

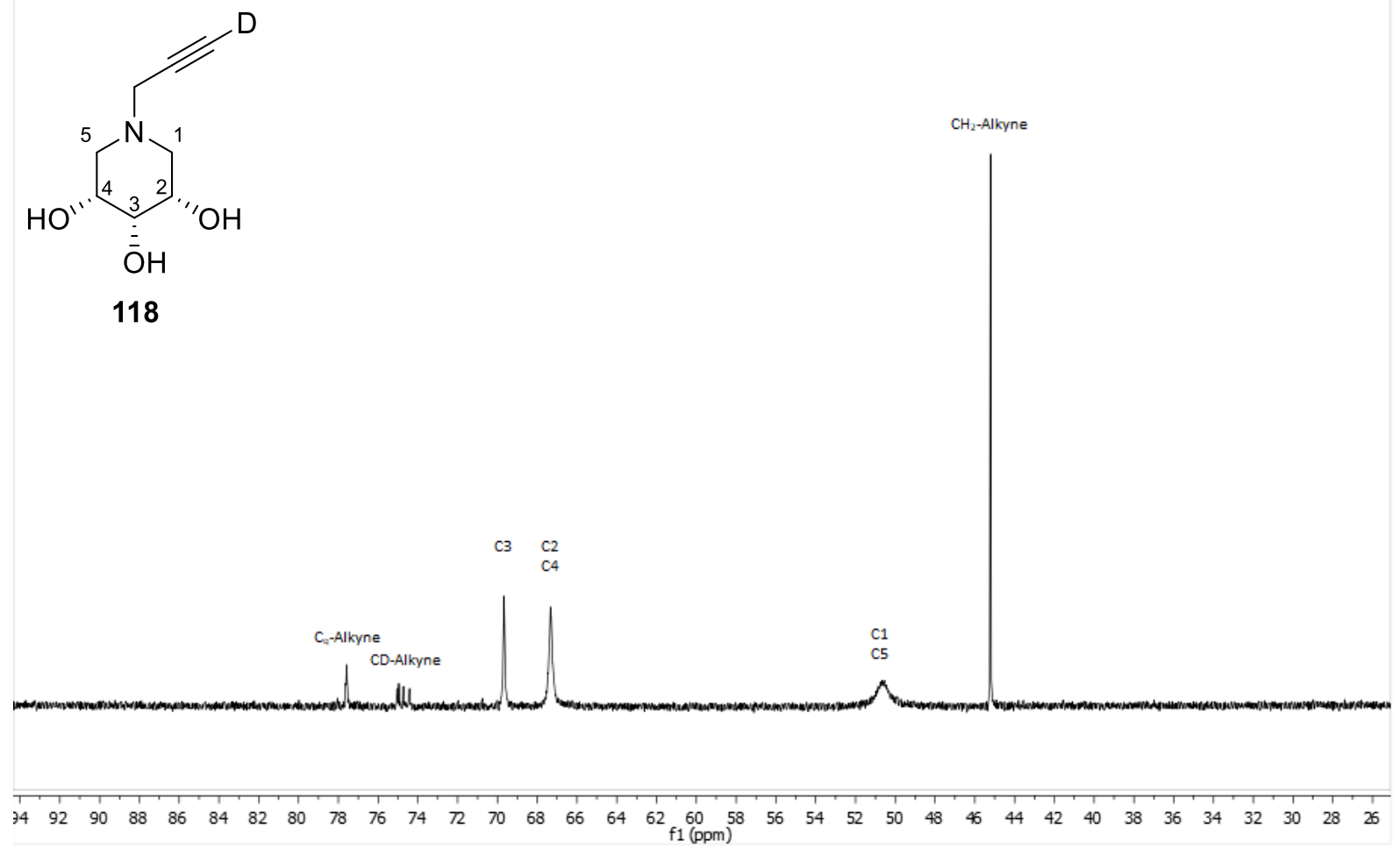

Figure 14: ${ }^{13} \mathrm{C}-\mathrm{NMR}$ spectrum of 119, highlighting the triplet at approx. $74.7 \mathrm{ppm}$

Another unexpected observation was made in the ${ }^{13} \mathrm{C}-\mathrm{NMR}$ spectrum of $\mathbf{1 1 5}$ (Figure 14). Through HMBC 2D NMR analysis, the cluster of three peaks observed at $74.7 \mathrm{ppm}$ was determined to correspond to the terminal alkyne carbon. This pattern is reminiscent of the residual solvent peaks of $\mathrm{CDCl}_{3}$ in ${ }^{13} \mathrm{C}-\mathrm{NMR}$ spectra, where the single carbon peak is split into three separate peaks. Because deuterium has a spin type of 1 , three separate peaks are produced for the carbon it is bonded with. It is believed that the relatively high acidity of the terminal alkyne proton $(\mathrm{pKa}=26)$ allowed the proton to be displaced by a deuterium atom (118), which subsequently causes the terminal carbon signal to split into three peaks. This theory is further supported by the ${ }^{1} \mathrm{H}-\mathrm{NMR}$ spectrum, where no signal is observed for a terminal alkyne proton (Figure 15). 


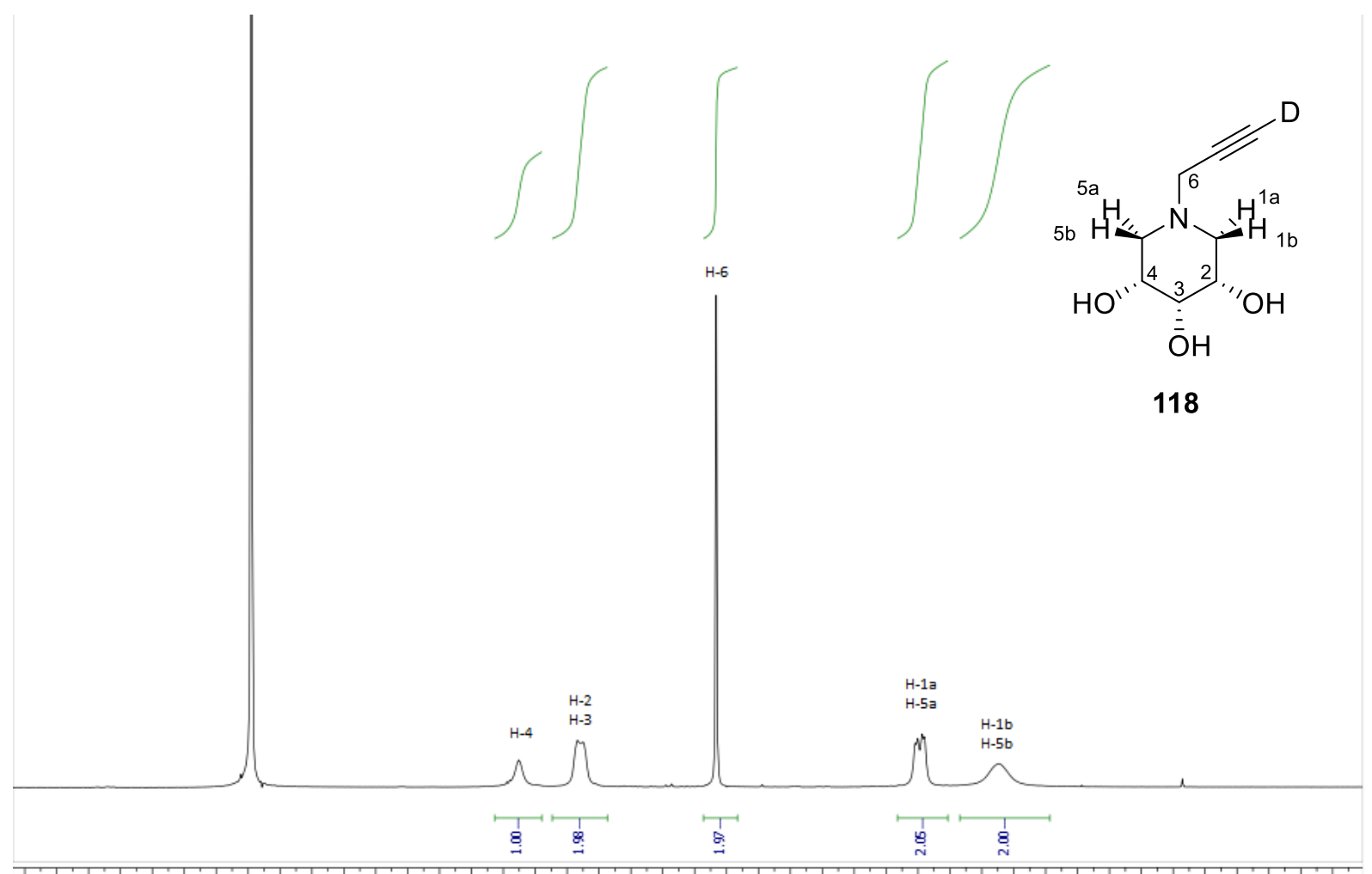

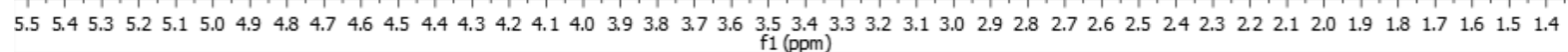

Figure 15: The ${ }^{1} \mathrm{H}-\mathrm{NMR}$ spectrum of 118

One last observation supporting this notion is found by HRMS analysis of the NMR sample that produced the spectra. So far, all piperidine triols have shown to appear as protonated ions in the HRMS spectra, but 114 was observed in a M+2 state, which corresponds to the deuterated product in terms of mass. This observation was also made in the D-xylose derived $N$-propargyl azasugar 104, where a $M+2$ peak was observed in place of the initially expected $M+1$ signal. 


\subsection{L-arabinose derived piperidine triols}

With two piperidine triol series finished, the next goal was to synthesise the first asymmetric piperidine triol starting from L-arabinose (Scheme 27). Analogous to the preparation of previous starting materials, L-arabinose was subjected to a Fischer glycosidation, which afforded methyl Larabinoside 119 in 93\% yield. Characterisation of the product was done using 1D and 2D NMR experiments and chemical shift values are consistent with previous studies. ${ }^{75}$ Subsequent iodination using iodine and triphenylphosphine and imidazole gave methyl 5-iodo-L-arabinoside $\mathbf{1 2 0}$ in 81\% yield. Characterisation by NMR spectroscopy revealed ${ }^{13} \mathrm{C}$ alkyl halide signals at 7.4 and 5.5 for the $\beta$ - and $\alpha$-anomer respectively, which is consistent with reported values for its enantiomer. ${ }^{63}$ Acidic hydrolysis of the methoxy group was found to proceed slower than for previous substrates, but nevertheless reached completion after $1 \mathrm{~h}$ at reflux using $\mathrm{HCl}(0.1 \mathrm{M}$, aq.). Subjection to ammonia and sodium cyanoborohydride afforded (3S,5S)-piperidine-3,4,5-triol 33 as a white solid in 92\% yield. The most successful synthesis of this azasugar was reported in 2011 by Chang et al., ${ }^{76}$ having obtained the azasugar through a combination of solid-phase and solution-phase synthesis from Larabinose in $60 \%$ overall yield over 9 steps. With a total yield of $69 \%$ over four steps, this methodology has vastly surpassed previous total syntheses of this azasugar and is the shortest and most high yielding synthetic route to date for the synthesis of (3S,5S)-piperidine-3,4,5-triol. This azasugar has had limited biological testing, but was found to be a potent inhibitor of $\beta$-galactosidase with an $\mathrm{IC}_{50}$ value of $0.75 \mu \mathrm{M}$ and $\alpha$-glucosidase with an $\mathrm{IC}_{50}$ value of $1.88 \mu \mathrm{M}$ [29].<smiles>OC[C@H]1O[C@@H](O)[C@@H](O)[C@@H]1O</smiles>

83<smiles>O[C@H]1CNC[C@@H](O)[C@@H]1O</smiles>

33

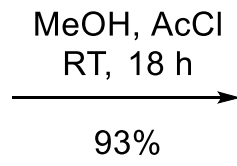

$93 \%$<smiles>CO[C@H]1O[C@H](CO)[C@@H](O)[C@H]1O</smiles>

119 $81 \%$ Imidazole, THF, reflux, $3 \mathrm{~h}$

1) $\mathrm{HCl}(0.1 \mathrm{M}$, aq.), reflux, $1 \mathrm{~h}$

2) $\mathrm{NH}_{3}$ (aq. $28 \% \mathrm{w} / \mathrm{w}$ ) $\mathrm{NaBH}_{3} \mathrm{CN}$, 19 h, RT<smiles>CO[C@H]1O[C@H](CI)[C@@H](O)[C@H]1O</smiles>

$92 \%$ (from 120) 


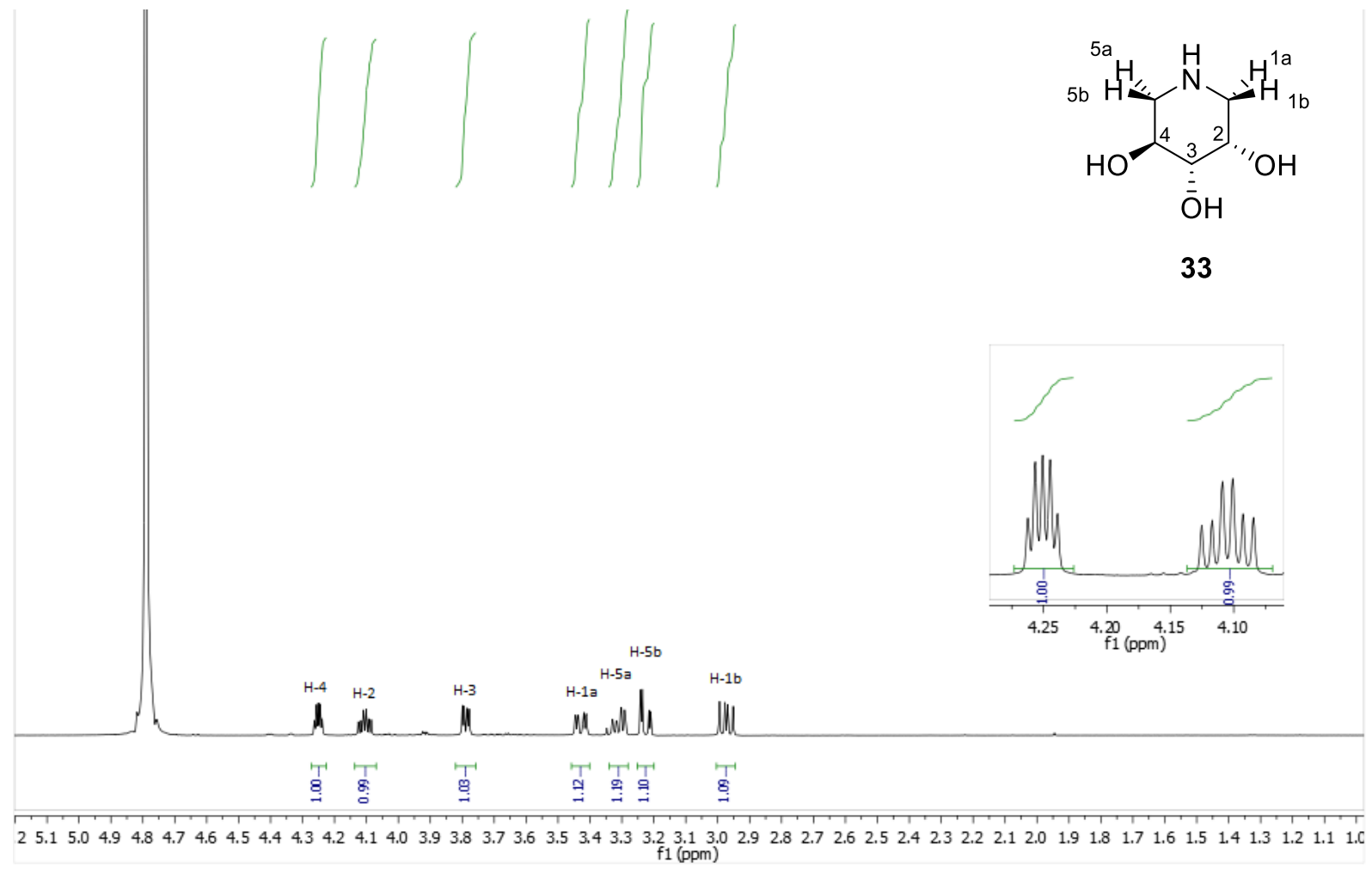

Figure 16: The ${ }^{1} \mathrm{H}-\mathrm{NMR}$ spectrum of $(3 \mathrm{~S}, 5 \mathrm{~S})$-piperidine-3,4,5-triol

Since (3S,5S)-piperidine-3,4,5-triol is asymmetric $\left([\alpha]_{D}^{20}=+6.1\right)$, all ring protons were expected to have unique chemical environments. Indeed, the ${ }^{1} \mathrm{H}-\mathrm{NMR}$ spectrum of $\mathbf{3 3}$ was found to contain seven individual signals (Figure 16). Ring protons H-2 and H-4 are no longer identical and thus produce separate peaks at 4.10 and $4.25 \mathrm{ppm}$ respectively. In addition, all protons on the $\mathrm{C} 1$ and C5 positions now produce unique shifts at 3.43, 3.31, 3.22 and $2.97 \mathrm{ppm}$ due to the different stereochemistry of the neighbouring protons on the C2 and C4 positions. Lastly, the H-3 signal split as a doublet of doublets instead of a triplet. All peaks are observed to be doublets of doublets, with the exception of the H-2 and H-4 proton peaks, which appear as doublets of triplets. 


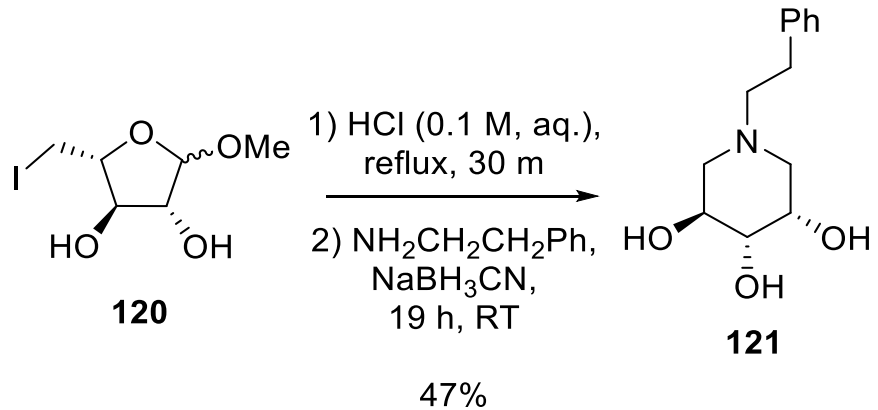

Scheme 28: The synthesis of (3S,5S)-1-(2-phenylethyl)piperidine-3,4,5-triol from methyl 5-iodo-L-arabinoside

Due to time constraints for this project, only one $N$-alkyl derivative was prepared to allow sufficient time for the synthesis of piperidine triols from D-arabinose. To this end, the synthesis of the $\mathrm{N}$ phenylethyl azasugar was attempted, utilising 2-phenylethylamine in the original procedure (Scheme 28). Subsequent purification by silica flash column chromatography afforded the desired product 121 in 47\% yield. This azasugar has not had studies reporting on its biological activity, nor on preparation. This body of work therefore represents the first example of the synthesis of this novel azasugar in a short and high yielding synthetic route.

The synthesis of $\mathbf{1 2 1}$ was found to be generally as low yielding as D-xylose derived N-phenylethyl azasugar 102. This suggests that the by-product commonly found in the $\mathrm{D}$-xylose derived azasugar series may also be present in the synthesis of L-arabinose derived piperidine triols. Indeed, analysis by ${ }^{1} \mathrm{H}$-NMR spectroscopy reveals the presence of a by-product in a 0.7:1 ratio of byproduct:product, an even greater ratio than what was initially observed in the synthesis of $N$-alkyl azasugar derivatives from $\mathrm{D}$-xylose. However, the by-product is yet to be confirmed as the common furanose by-product, since full characterisation by NMR experiments was complicated by the inability to fully separate it from the desired product. Since HRMS analysis shows no obvious signals for other impurities, it is likely that the by-product is the common furanose by-product due to its identical mass to the azasugar product. 


\subsection{D-arabinose derived piperidine triols}

Having completed the total synthesis of two L-arabinose derived piperidine triols, it was then decided to obtain the same targets derived from $D$-arabinose. The total synthesis of $(3 R, 5 R)$ piperidine-3,4,5-triol (32) began with the Fischer glycosidation of D-arabinose, obtaining methyl D-arabinoside (122) in 81\% yield (Scheme 29). Characterisation of the product was done using 1D and 2D NMR experiments. The presence of a high intensity singlet at $3.39 \mathrm{ppm}$ indicated the formation of a methoxy group in the $\alpha$ configuration as in previous studies. ${ }^{66}$ The iodination of methyl D-arabinoside was done using iodine and triphenylphosphine in presence of imidazole, resulting in a $15 \%$ yield of methyl 5 -iodo-D-arabinose (123). The lower yield obtained from this iodination is thought to be due to a technical error rather than a flaw in the methodology. Nevertheless, the synthesis of $(3 R, 5 R)$-piperidine triol (32) was commenced by acidic hydrolysis using $\mathrm{HCl}$, which proceeded to completion after $1 \mathrm{~h}$ at reflux. Addition of ammonia followed by sodium cyanoborohydride gave (3R,5R)-piperidine triol (32) in 30\% yield. While this yield is significantly lower compared to the yield obtained from the synthesis of $(3 S, 5 S)$-piperidine triol (33), it is thought that adjusting the method of purification will result in higher yields more comparable to the synthesis of $\mathbf{3 3}$. The most high yielding synthesis of $(3 R, 5 R)$-piperidine triol (32) was reported in 2011 by Chang et al., ${ }^{76}$ having obtained the azasugar through a combination of solid-phase and solution-phase synthesis from D-arabinose in 60\% overall yield over 9 steps. In this body of work, (3R,5R)-piperidine triol (32) was obtained in an overall yield of $4 \%$ over four steps. While this is significantly lower than previous studies, it is believed that the iodination reaction of methyl $\alpha, \beta$-arabinofuranoside should proceed in much higher yields. Furthermore, the hydrolysis followed by reductive amination steps are expected to be possible in yields similar to those obtained in the synthesis of the absolute stereoisomer (3S,5S)-piperidine triol (33), which may result in an overall yield surpassing previous syntheses in efficiency. 
<smiles>OC[C@H]1O[C@H](O)C(O)[C@@H]1O</smiles>

82<smiles>O[C@H]1CNC[C@@H](O)[C@H]1O</smiles>

32

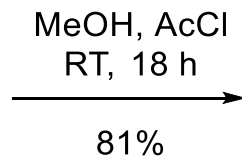<smiles>CO[C@H]1O[C@H](CO)[C@@H](O)[C@H]1O</smiles>

122

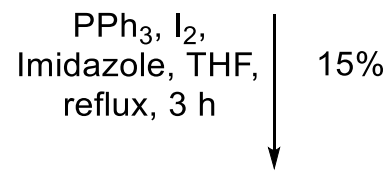

1) $\mathrm{HCl}(0.1 \mathrm{M}$, aq. $)$, reflux, $1 \mathrm{~h}$

2) $\mathrm{NH}_{3}$ (aq. $28 \% \mathrm{w} / \mathrm{w}$ ) $\mathrm{NaBH}_{3} \mathrm{CN}$,

$19 \mathrm{~h}, \mathrm{RT}$<smiles>CO[C@H]1O[C@H](CI)[C@@H](O)[C@H]1O</smiles>

123

$30 \%($ from 123)

Scheme 29: The synthesis of $(3 R, 5 R)$-piperidine triol from D-arabinose

Unsurprisingly, the ${ }^{1} \mathrm{H}-\mathrm{NMR}$ spectrum of $(3 \mathrm{R}, 5 \mathrm{R})$-piperidine-3,4,5-triol is identical to that of (3S,5S)-piperidine-3,4,5-triol, the only difference being that the peaks corresponding to $\mathrm{H}-4, \mathrm{H}-2$, H-5 and H-1 now instead correspond to $\mathrm{H}-2, \mathrm{H}-4, \mathrm{H}-1$ and $\mathrm{H}-5$ respectively (Figure 17). Confirming the stereochemistry was done by optical rotation measurements $\left([\alpha]_{D}^{20}=-23.7\right)$, which corresponds to previously reported values. ${ }^{48}$ With limited biological testing, (3R,5R)-piperidine3,4,5-triol is known only to be a moderate inhibitor of $\beta$-galactosidase from Aspergillus orizae with an $\mathrm{IC}_{50}$ value of $50 \mu \mathrm{M}^{74}$ 


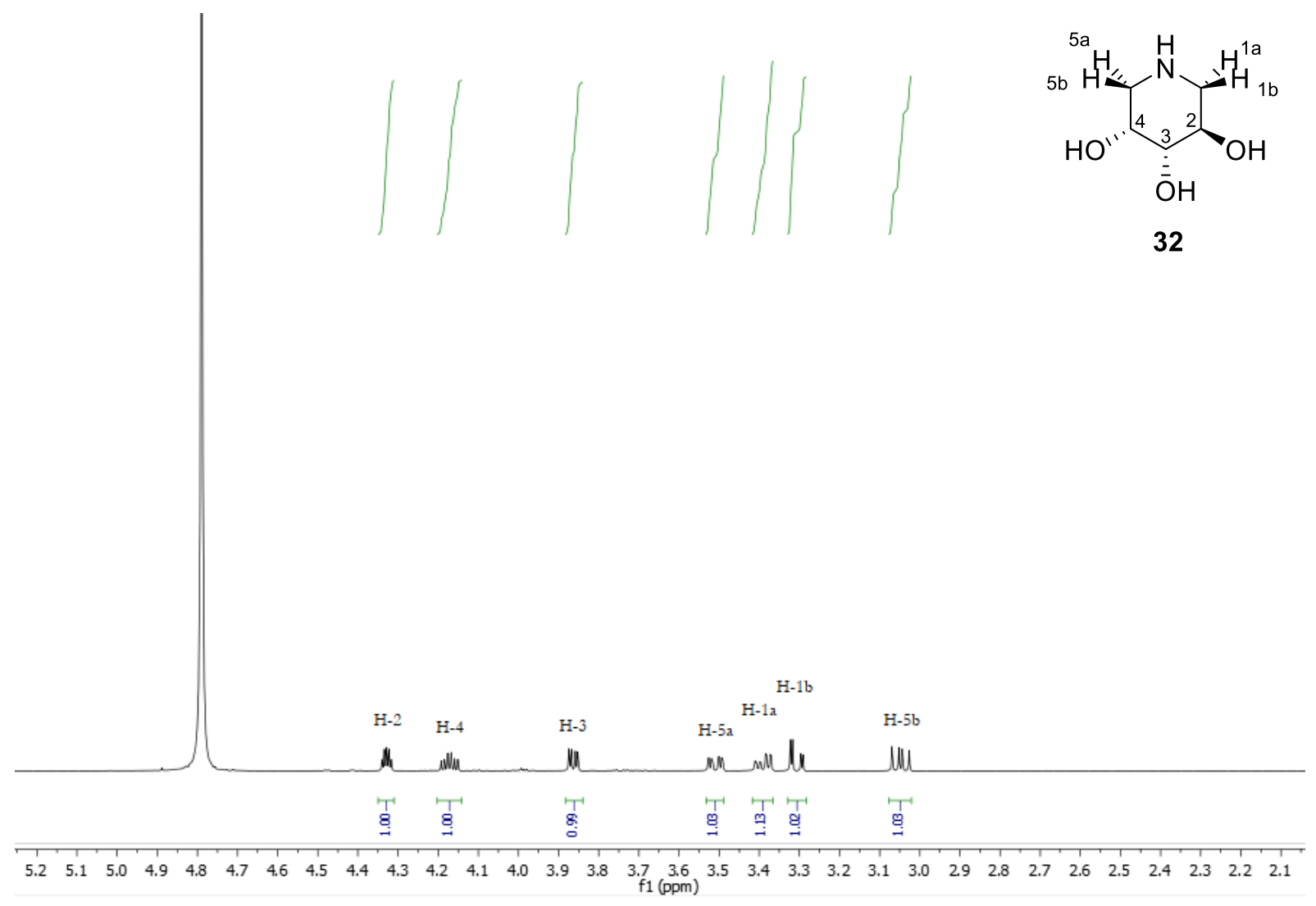

Figure 17: The ${ }^{1} \mathrm{H}-\mathrm{NMR}$ spectrum of $(3 R, 5 R)$-piperidine-3,4,5-triol<smiles>CO[C@H]1O[C@H](CI)[C@@H](O)[C@H]1O</smiles>

123
1) $\mathrm{HCl}(0.1 \mathrm{M}$, aq. $)$, reflux, $30 \mathrm{~m}$

2) $\mathrm{NH}_{2} \mathrm{CH}_{2} \mathrm{CH}_{2} \mathrm{Ph}, \mathrm{HO}$ "' $\mathrm{NaBH}_{3} \mathrm{CN}$, 19 h, RT

$50 \%$<smiles>O[C@H]1CN(CCc2ccccc2)C[C@@H](O)[C@H]1O</smiles>

124

Scheme 30: The synthesis of $(3 R, 5 R)-1-(2-$ phenylethyl)piperidine-3,4,5-triol from methyl 5-iodo-D-arabinoside

Next, the synthesis of $N$-phenylethyl azasugar was attempted, utilising 2-phenylethylamine as in the original procedure (Scheme 30). Subsequent purification by silica flash column chromatography afforded the desired product 124 in 50\% yield. This azasugar has not had studies reporting on its biological activity, nor on its preparation. This body of work therefore represents the first example of the synthesis of this novel azasugar in a short and high yielding synthetic route. 


\subsection{Summary}

Table 2: An overview of yields obtained from the synthesis of each piperidine triol

\begin{tabular}{|c|c|c|c|c|}
\hline Substrate & Amine & Product & $\begin{array}{c}\text { Total overall } \\
\text { yield (4 steps) }\end{array}$ & $\begin{array}{c}\text { Literature overall } \\
\text { yield }\end{array}$ \\
\hline D-xylose & Ammonia & 30 & $45 \%$, & $40 \%$ (5 steps $^{48}$ \\
\hline D-xylose & Benzylamine & 101 & $23 \%$ & $42 \%(4 \text { steps })^{69}$ \\
\hline D-xylose & $\begin{array}{l}\text { 2-phenylethyl } \\
\text { amine }\end{array}$ & 102 & $27 \%$ & - \\
\hline D-xylose & n-butylamine & 103 & $32 \%$ & $35 \%(6 \text { steps })^{71}$ \\
\hline D-xylose & Propargylamine & 104 & $35 \%$ & - \\
\hline D-xylose & Ethanolamine & 105 & $41 \%$ & \\
\hline D-ribose & Ammonia & 31 & $40 \%$ & $24 \%(4 \text { steps })^{57}$ \\
\hline D-ribose & $\begin{array}{l}\text { 2-phenylethyl } \\
\text { amine }\end{array}$ & 113 & $30 \%$ & - \\
\hline D-ribose & n-butylamine & 45 & $28 \%$ & $18 \%(7 \text { steps })^{51}$ \\
\hline D-ribose & Propargylamine & 114 & $27 \%$ & - \\
\hline D-ribose & Ethanolamine & 115 & $32 \%$ & - \\
\hline L-arabinose & Ammonia & 33 & $69 \%$ & $60 \%(9 \text { steps })^{76}$ \\
\hline L-arabinose & $\begin{array}{l}\text { 2-phenylethyl } \\
\text { amine }\end{array}$ & 121 & $35 \%$ & - \\
\hline D-arabinose & Ammonia & 32 & $4 \%$ & $60 \%(9 \text { steps })^{76}$ \\
\hline D-arabinose & $\begin{array}{l}\text { 2-phenylethyl } \\
\text { amine }\end{array}$ & 124 & $6 \%$ & - \\
\hline
\end{tabular}

In summary, a total of 15 piperidine triols have been synthesised from four different pentose substrates, ranging in overall yields from 4-69\%. Seven of these piperidine triols are novel 
compounds with no known synthesis or biological activity studies. Out of the remaining seven total syntheses of piperidine triols, four previous total syntheses have been surpassed as the shortest and most high yielding route to date for these compounds. Given more time, it is thought that the remaining three piperidine triols can be obtained in yields surpassing literature yields. Nevertheless, the original methodology developed within our research group by Hunt-Painter for the synthesis of azasugars minimising the use of protecting groups has proven to be applicable to pentoses for the synthesis of a wide array of piperidine triols and analogues in excellent yields and purities. 


\section{Conclusions}

The goal of this Master's project was to expand the applicability and viability of a methodology that was previously developed and employed within our research group for the efficient four-step, 3-pot synthesis of azasugars from readily available carbohydrate building blocks while minimising the use of protecting groups. In this study, the methodology has been successfully applied for the synthesis of piperidine triols from four unique pentoaldoses in yields varying from $30-92 \%$. All attempts at syntheses of azasugars have been successful and as such no observable limit to amines applicable within this methodology was found. Complications were expected to be most likely to occur during the reductive amination step, which have arisen in the form of the formation of a linear by-product which forms under acidic conditions, and the formation of a furanose by-product which forms primarily under more basic conditions. The formation of the linear by-product proved to be easily circumvented by ensuring the $\mathrm{pH}$ was not lower than 7 before addition of the reducing agent. Even mildly acidic conditions of $\mathrm{pH}=6$ were found to produce only the linear by-product. Efforts within this thesis to suppress the formation of the furanose by-product have not been successful, but have granted insight into certain aspects of this reaction pathway, such as the relevance of $\mathrm{pH}$ within the reductive amination step. The purification process was found to be the most complicated aspect of the methodology, owed primarily to the highly polar nature of these compounds and the formation of the furanose by-product. Although the lowest yields obtained within this project were still moderate, it is envisioned that the methodology has the potential for superior yields. It is therefore hypothesised, provided more time, yields could be increased up to 80 or $90 \%$, as suggested by ${ }^{1} \mathrm{H}-\mathrm{NMR}$ analysis of crude reaction mixtures before purification.

Scaleup of the methodology as reported is expected to be low yielding, owing to the complication of purification due to presence of the furanose byproduct. With further development of the methodology to prevent the formation of the furanose byproduct, scaleup should be feasible and high yielding as there would be no impurities to significantly complicate purification processes. It is therefore essential that the methodology is further refined to maximise yields and to further validate the methodology for large-scale production of piperidine triols. 


\section{Future prospects}

Some future prospects to continue this line of work would be to pursue the methodology into obtaining the piperidine triols from D-, and L-arabinose. Due to time constraints, the library of 20 azasugars to be obtained was incomplete, lacking primarily in the syntheses starting from both enantiomers of arabinose. The results from these syntheses would provide relevant insight into the existing issue of the formation of furanose by-product and would complete the research question. Next, it is of great importance to find the key modification necessary to prevent the formation of the furanose by-product. This issue is believed to be the greatest detriment to the methodology both by lowering the yield directly and by significantly complicating the purification of the desired product. If a pathway is established wherein no additional main side products are formed, it is expected that the synthesis of the remaining piperidine triols should proceed without any further issues. Another prospect is to further probe the versatility of the methodology in the different types of amines that can be used. An array of amines ranging from relatively small and flexible such as ethanolamine, to long and bulky such as 2-phenylethylamine have already been trialled and proven to be applicable. However, it is proposed that amines such as tert-butylamine or ethylenediamine should provide new and unique challenges. While 2-phenylethylamine is bulky, its amine functionality is still relatively open and unrestrained. The use of tert-butylamine will truly challenge the viability of bulky and rigid amines in this methodology. In addition, ethylenediamine provides another amine handle, which in turn could allow the azasugar product to function as an amine in the synthesis of a piperidine triol dimer (Scheme 31). 


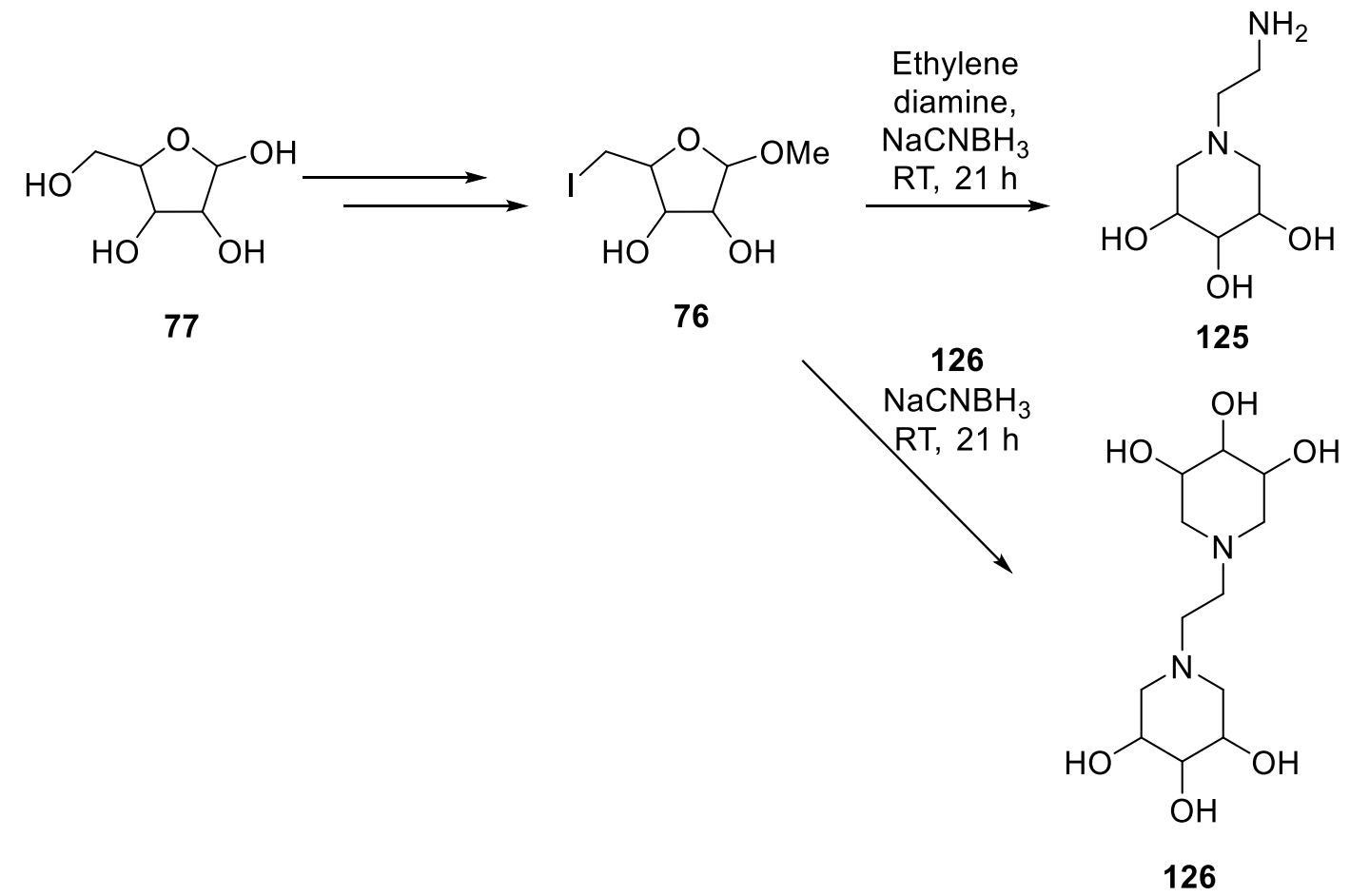

Scheme 31: Proposed synthetic route towards the synthesis of 126

This form of compound has not previously been reported. It is proposed that this class of compounds should be available through the synthesis of azasugar $\mathbf{1 2 5}$ followed by its use as an amine in the synthesis of $\mathbf{1 2 6 .}$

Lastly, with the synthesis of $N$-propargyl derivatised azasugars, a new array of possibilities is accessible as the triple bond in the propargyl functionality acts as a chemical handle to allow different types of click chemistry. Reactions such as copper-catalysed azide-alkyne cycloadditions (CuAAC) and ruthenium-catalysed azide-alkyne cycloadditions help drug discovery processes by significantly simplifying steps in total syntheses of drug-like compounds. Having seen that piperidine triols as standalone compounds can have powerful biological activities, it is a whole new world of possibilities to consider piperidine triols with added triazole functionalities. In addition to click chemistry, a wide variety of different reactions are possible on a highly reactive alkyne functionality. From addition reactions to oxidation and reduction reactions, alkynes offer a myriad of possibility in derivatisation. Furthermore, alkynes can be reduced to alkenes which, in turn, are also great centres for reactions and derivatisation. 


\section{Acknowledgements}

I'd like to thank Associate professor Mattie Timmer and Associate professor Bridget Stocker for allowing me to work in the Immunoglycomics research group at Victoria University of Wellington and for their guidance during my Master's project. I'd also like to thank Dr. Alex Hunt-Painter for his guidance and for helping me step into the world of azasugar synthesis and for providing the very foundation for this project with his initial methodology. I have learned much more than I thought I was capable of within these two years and I am grateful I was granted the opportunity to do so. Although not every day was as smooth as the next, I enjoyed working on this project and am proud to have been a part of this study. Next, I thank Ian Vorster for his tireless and swift maintenance of NMR and LCMS equipment and for his assistance in acquiring analyses. Kris, thanks for the great chats when I needed them. I'd also like to thank every other member of the Immunoglycomics group at Victoria University of Wellington. Each of you have always been available for support and have been an immense help in keeping me moving forward and even relented from playing some of my less preferred music in the lab, which was greatly appreciated. A great thank you goes to the donors of the Curtis-Gordon Research scholarship in Chemistry for the funding provided during my project. My family has also been an infinite source of support and care, helping me stay steady and focused on the most important task at hand. To my father Fred, my mother Liarne, my sister Kimberley and her partner Eric, my grandmother Jillie and her partner Dave, I extend the most sincere gratitude, for I could not have gotten through a fraction of this work without your support. Aunty Lynne, I thank you sincerely for the motivational support and for the immense financial support rivalling that of some scholarships granted to students for research. It truly hasn't been said enough, but I thank each of you. Next, I thank my intercontinental friend Fabian Hensbergen for his support, for encouraging me when needed, and for the endless laughs. It's about time you showed up on the other southern hemisphere, lad. Lastly, a thank you to my friend Cameron Johnson for helping me keep my sanity during the worst flatting experience I've ever experienced and for the motivational support beyond said experience. 


\section{Experimental section}

\section{List of chemicals}

\section{Reagents}

Acetyl chloride (Reagent grade 98\% (Sigma Aldrich))

Ammonia (aq. 35\% w/w (Fisher Scientific))

$\mathrm{D}(-)$-Arabinose (99+\% (Acros Organics))

L(+)-Arabinose (Anhyd. (Sigma Aldrich))

Benzylamine (Sigma Aldrich)

n-Butylamine (Reagent grade (Unilab))

Ethanolamine (99+\%, A.C.S. reagent (Sigma Aldrich))

Hydrochloric acid (Aq. 32\% w/w (Univar))

Imidazole (Apollo Scientific)

2-Phenylethylamine (Hopkin \& Williams)

Propargylamine (98\% (GC) (AK Scientific))

D-Ribose (Carbosynth)

Sodium cyanoborohydride (Chem-Impex International, Inc.)

Triphenylphosphine (99\% (Acros Organics))

$\mathrm{D}(+)$-Xylose (99\% minimum (Sigma Aldrich))

\section{Solvents}

$\mathrm{D}_{2} \mathrm{O}(>99.9$ atom \% D (Apollo Scientific))

Dichloromethane (HPLC grade (Fisher Scientific))

Ethanol (Absolute (Fisher Scientific))

Ethyl Acetate (Pacific Sphere Limited)

Hexane (Vigor Sphere Pte Ltd.)

Methanol (Analytical Reagent Grade (Fisher Scientific))

Tetrahydrofuran (min $99.9 \% \mathrm{C}_{4} \mathrm{H}_{8} \mathrm{O}$ (stabilised with up to $25 \mathrm{ppm}$ BHT) (Chemsolute)) 


\section{General Experimental}

Unless otherwise stated, all reactions are performed at room temperature, exposed to air and at atmospheric pressure. THF was freshly distilled from $\mathrm{LiAlH}_{4}$ prior to use. Pure water was obtained by using a RiOs Millipore system. Reactions were monitored by TLC analysis using MachereyNagel brand silica gel coated polyester plates $(0.2 \mathrm{~mm}$, Polygram Sil G/UV 254) with detection either by $10 \% \mathrm{H}_{2} \mathrm{SO}_{4}$ in EtOH followed by charring for methyl and methyl iodo-glycosides, or a $0.1 \mathrm{M}$ solution of ninhydrin in $\mathrm{EtOH}$ followed by charring at approx. $150{ }^{\circ} \mathrm{C}$. Where applicable, detection by UV was done at $253 \mathrm{~nm}$. Flash column chromatography was performed using Kieselgel 60 (0.04-0.063 mm) from Roth, reversed phase column chromatography was done using HP-20 beads (Supelco). Nuclear Magnetic Resonance spectra were recorded at $20{ }^{\circ} \mathrm{C}$ in $\mathrm{D}_{2} \mathrm{O}$ unless otherwise stated, using a Varian INOVA operating at $500 \mathrm{MHz}$ unless otherwise stated. Chemical shifts are given in ppm ( $\delta$ ) values relative to tetramethylsilane. NMR peak assignments were made by COSY, HSQC and HMBC 2D experiments. High resolution mass spectra were recorded on a Waters Q-TOF premier ${ }^{\mathrm{TM}}$ Tandem Mass spectrometer using positive electro-spray ionisation. Optical Rotations were recorded on a Perkin-Elmer 241 polarimeter at $589 \mathrm{~nm}$ (sodium D-line). Infrared spectra were recorded as thin films using a Bruker FTIR spectrometer equipped with an Attenuated Total Reflectance (ATR) sampling accessory and are reported in wave numbers $\left(\mathrm{cm}^{-1}\right)$.

\section{General procedure for the synthesis of methyl glycosides}

To a solution of pentose $(1.00 \mathrm{~g})$ in $\mathrm{MeOH}(5 \mathrm{ml} / \mathrm{mmol})$ was added $\mathrm{AcCl}(15 \mu \mathrm{l} / \mathrm{mmol})$ and the reaction was stirred at room temperature for $18 \mathrm{~h}$. The reaction was then quenched with Dowex $\left(\mathrm{OH}^{-}\right)$, filtered, concentrated in vacuo and purified by flash column chromatography, giving the crude methyl glycoside as an oil.

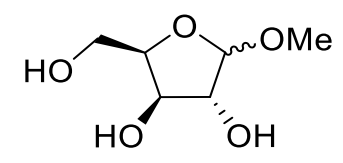

Methyl $\alpha, \beta$-D-xylofuranoside (79). Subjecting D-xylose (2.00 g, 13.3 $\mathrm{mmol}$ ) to the general procedure for the synthesis of methyl glycosides gave xyloside $\mathbf{7 9}$ as a clear oil in a 1.1:1 ratio of $\alpha$ - and $\beta$-isomers $(2.05 \mathrm{~g}, 12.5 \mathrm{mmol}, 94 \%) . \mathrm{R}_{f}=0.47$ (5:1 EtOAc/MeOH); $[\alpha]_{D}^{20}=+9.4(\mathrm{c}=0.11, \mathrm{MeOH}) ; \mathrm{IR}\left(\right.$ film) $3356,2934,2844,1081 \mathrm{~cm}^{-1} ;{ }^{1} \mathrm{H}$ NMR $\left(500 \mathrm{MHz}, \mathrm{D}_{2} \mathrm{O}\right)$ $\delta 5.00\left(\mathrm{~d}, J_{1,2}=4.5 \mathrm{~Hz}, 1 \mathrm{H}, \mathrm{H}-1 \alpha\right), 4.90(\mathrm{~s}, 1 \mathrm{H}, \mathrm{H}-1 \beta), 4.35$ (dt, $J_{3,4}=J_{4,5 \mathrm{a}}=4.8, J_{4,5 \mathrm{~b}}=7.6 \mathrm{~Hz}, 1 \mathrm{H}$, $\mathrm{H}-4 \beta), 4.30\left(\mathrm{dd}, J_{2,3}=5.6, J_{3,4}=6.2 \mathrm{~Hz}, 1 \mathrm{H}, \mathrm{H}-3 \alpha\right), 4.25\left(\mathrm{td}, J_{4,5 \mathrm{a}}=3.7, J_{3,4}=J_{4,5 \mathrm{~b}}=6.2 \mathrm{~Hz}, 1 \mathrm{H}, \mathrm{H}-\right.$ 
$4 \alpha), 4.22\left(\mathrm{dd}, J_{2,3}=1.8, J_{3,4}=5.0 \mathrm{~Hz}, 1 \mathrm{H}, \mathrm{H}-3 \beta\right), 4.15\left(\mathrm{dd}, J_{1,2}=4.5, J_{2,3}=5.6 \mathrm{~Hz}, 1 \mathrm{H}, \mathrm{H}-2 \alpha\right), 4.12$ (m, 1H, H-2ß), 3.84 (dd, $J_{4,5 \mathrm{a}}=4.4, J_{5,5 \mathrm{~b}}=11.9 \mathrm{~Hz}, 1 \mathrm{H}, \mathrm{H}-5 \mathrm{a} \beta$ ), 3.77 (dd, $J_{4,5 \mathrm{a}}=3.7, J_{5 \mathrm{a}, 5 \mathrm{~b}}=11.9$ $\mathrm{Hz}, 1 \mathrm{H}, \mathrm{H}-5 \mathrm{a} \alpha), 3.74\left(\mathrm{dd}, J_{4,5 \mathrm{~b}}=7.6, J_{5 \mathrm{a}, 5 \mathrm{~b}}=11.9 \mathrm{~Hz}, 1 \mathrm{H}, \mathrm{H}-5 \mathrm{~b} \beta\right), 3.70\left(\mathrm{dd}, J_{4,5 \mathrm{~b}}=6.1, J_{5,5 \mathrm{~b}}=11.9\right.$ $\mathrm{Hz}, 1 \mathrm{H}, \mathrm{H}-5 \mathrm{~b} \alpha$ ), 3.44 (s, 3H, $\beta$-OMe), 3.39 (s, 3H, $\alpha-\mathrm{OMe}$ ); ${ }^{13} \mathrm{C}$ NMR (125 MHz, $\mathrm{D}_{2} \mathrm{O}$ ) $\delta$ 108,5

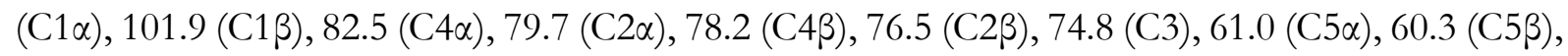
55.5 ( $\beta$-OMe), $55.0(\alpha-\mathrm{OMe})$; HRMS(ESI) $m /$ z calcd. for $\left[\mathrm{C}_{6} \mathrm{H}_{12} \mathrm{O}_{5}+\mathrm{Na}\right]^{+}:$187.0577, obsd.: 187.0578.

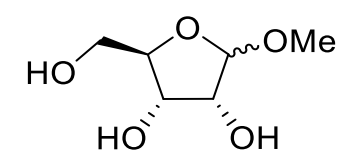

$\mathrm{mmol}$ ) to the general procedure for the synthesis of methyl glycosides gave riboside $\mathbf{1 1 1}$ as a pale yellow oil in a 1:5 ratio of $\alpha$ - and $\beta$-anomers $(3.8 \mathrm{~g}, 23.1 \mathrm{mmol}, 69 \%)$. $\mathrm{R}_{f}=0.55(11 \% \mathrm{MeOH}$ in EtOAc); $[\alpha]_{D}^{20}=-20.4(\mathrm{c}=1.42, \mathrm{MeOH}) ; \mathrm{IR}\left(\right.$ film) 3378, 2932, 2837, $1093 \mathrm{~cm}^{-1} ;{ }^{1} \mathrm{H}$ NMR $(500$ $\left.\mathrm{MHz}, \mathrm{D}_{2} \mathrm{O}\right) \delta 4.89\left(\mathrm{~d}, J_{1,2}=1.2 \mathrm{~Hz}, 1 \mathrm{H}, \mathrm{H}-1\right), 4.15\left(\mathrm{dd}, J_{2,3}=4.8, J_{3,4}=6.9 \mathrm{~Hz}, 1 \mathrm{H}, \mathrm{H}-3\right), 4.02(\mathrm{dd}$, $\left.J_{1,2}=1.2, J_{2,3}=4.8 \mathrm{~Hz}, 1 \mathrm{H}, \mathrm{H}-2\right), 4.00\left(\mathrm{td}, J_{4,5 a}=3.3, J_{3,4}=J_{4,5 \mathrm{~b}}=6.9 \mathrm{~Hz}, 1 \mathrm{H}, \mathrm{H}-4\right), 3.79$ (dd, $J_{4,5 \mathrm{a}}=$ 3.3, $\left.J_{5 a, 5 \mathrm{~b}}=12.3 \mathrm{~Hz}, 1 \mathrm{H}, \mathrm{H}-5\right), 3.60\left(\mathrm{dd}, J_{4,5 \mathrm{~b}}=6.5, J_{5 a, 5 \mathrm{~b}}=12.3 \mathrm{~Hz}, 1 \mathrm{H}, \mathrm{H}-5\right), 3.39$ (s, $\left.3 \mathrm{H}, \mathrm{OMe}\right)$; ${ }^{13} \mathrm{C}$ NMR (125 MHz, D $\left.2 \mathrm{O}\right) \delta 107.8$ (C1), 82.7 (C4), 74.1 (C2), 70.1 (C3), 62.6 (C5), 55.0 (OMe); HRMS(ESI) $m / z$ calcd. for $\left[\mathrm{C}_{6} \mathrm{H}_{12} \mathrm{O}_{5}+\mathrm{Na}\right]^{+}: 187.0577$, obsd.: 187.0575.

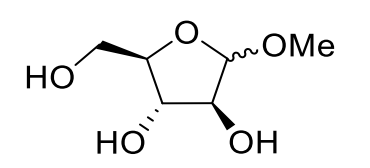

Methyl $\alpha, \beta$-D-arabinofuranoside (122). Subjecting D-arabinose (4.00 g, $26.6 \mathrm{mmol}$ ) to the general procedure for the synthesis of methyl glycosides gave arabinoside 122 as a colourless oil in a 1:0.9 ratio of $\alpha$ - and $\beta$-anomers (3.54 g, $21.6 \mathrm{mmol}, 81 \%)$. $\mathrm{R}_{f}=0.46(11 \%$ $\mathrm{MeOH}$ in EtOAc); $[\alpha]_{D}^{20}=+8.6(\mathrm{c}=0.93, \mathrm{MeOH})$; IR (film) 3346, 2928, 2836, $1003 \mathrm{~cm}^{-1} ;{ }^{1} \mathrm{H}$ NMR (500 MHz, D $2 \mathrm{O}) \delta 4.91$ (d, $\left.J_{1,2}=1.5 \mathrm{~Hz}, 1 \mathrm{H}, \mathrm{H}-1 \alpha\right), 4.87$ (d, $\left.J_{1,2}=4.7 \mathrm{~Hz}, 1 \mathrm{H}, \mathrm{H}-1 \beta\right), 4.12$ $\left(\mathrm{dd}, J_{1,2}=4.7, J_{2,3}=8.0 \mathrm{~Hz}, 1 \mathrm{H}, \mathrm{H}-2 \beta\right), 4.03(\mathrm{~m}, 1 \mathrm{H}, \mathrm{H}-2 \alpha), 4.02\left(\mathrm{td}, J_{4.5 a}=3.4, J_{3,4}=J_{4,5 \mathrm{~b}}=5.9 \mathrm{~Hz}\right.$, $1 \mathrm{H}, \mathrm{H}-4 \alpha), 3.98\left(\mathrm{t}, J_{2,3}=J_{3,4}=7.0 \mathrm{~Hz}, 1 \mathrm{H}, \mathrm{H}-3 \beta\right), 3.93\left(\mathrm{dd}, J_{2,3}=3.3, J_{3,4}=5.9 \mathrm{~Hz}, 1 \mathrm{H}, \mathrm{H}-3 \alpha\right), 3.87$ $\left(\operatorname{td}, J_{4,5 \mathrm{a}}=7.5, J_{3,4}=J_{4,5 \mathrm{~b}}=7.0 \mathrm{~Hz}, 1 \mathrm{H}, \mathrm{H}-4 \beta\right), 3.79\left(\mathrm{dd}, J_{4,5 \mathrm{a}}=3.4, J_{5,5 \mathrm{~b}}=12.3 \mathrm{~Hz}, 1 \mathrm{H}, \mathrm{H}-5 \mathrm{a \alpha}\right), 3.74$ $\left(\mathrm{dd}, J_{4,5 \mathrm{a}}=3.5, J_{5 \mathrm{a}, 5 \mathrm{~b}}=12.2 \mathrm{~Hz}, 1 \mathrm{H}, \mathrm{H}-5 \mathrm{a} \beta\right), 3.68\left(\mathrm{dd}, J_{4,5 \mathrm{~b}}=5.9, J_{5 \mathrm{a}, 5 \mathrm{~b}}=12.3 \mathrm{~Hz}, 1 \mathrm{H}, \mathrm{H}-5 \mathrm{~b} \alpha\right), 3.60$ $\left(\mathrm{dd}, J_{4,5 \mathrm{~b}}=7.0, J_{5 \mathrm{a}, 5 \mathrm{~b}}=12.2 \mathrm{~Hz}, 1 \mathrm{H}, \mathrm{H}-5 \mathrm{~b} \beta\right), 3.40$ (s, 3H, $\left.\beta-\mathrm{OMe}\right), 3.39$ (s, $\left.3 \mathrm{H}, \alpha-\mathrm{OMe}\right) ;{ }^{13} \mathrm{C} \mathrm{NMR}$

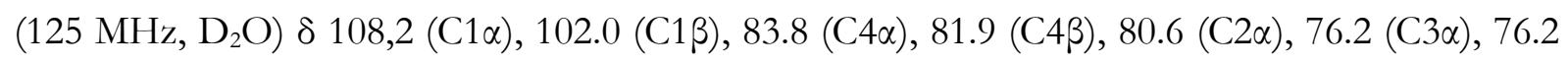

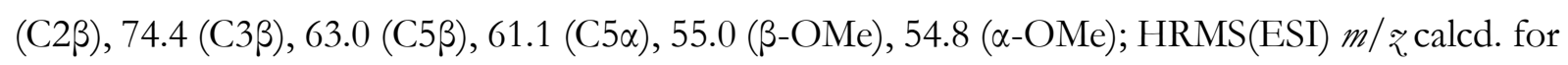
$\left[\mathrm{C}_{6} \mathrm{H}_{12} \mathrm{O}_{5}+\mathrm{Na}\right]^{+}:$187.0577, obsd.: 187.0574 . 


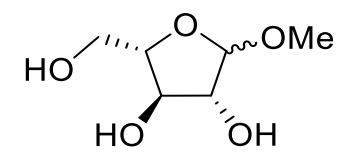

Methyl $\alpha, \beta$-L-arabinofuranoside (119). Subjecting L-arabinose (1.02 g, $6.80 \mathrm{mmol}$ ) to the general procedure for the synthesis of methyl glycosides gave arabinoside $\mathbf{1 1 9}$ as a colourless oil in a 1:0.9 ratio of $\alpha$ - and $\beta$-anomers (1.04 g, $6.34 \mathrm{mmol}, 93 \%) . \mathrm{R}_{f}=0.60$ and 0.49 for $\beta$ and $\alpha$ respectively $(5: 1 \mathrm{EtOAc} / \mathrm{MeOH}) ;[\alpha]_{D}^{20}=-18.8$ (c = 0.53, MeOH); IR (film) 3336,

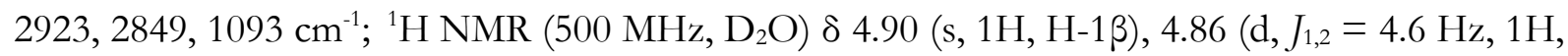
$\mathrm{H}-1 \alpha), 4.11\left(\mathrm{dd}, J_{1,2}=4.6, J_{2,3}=8.0 \mathrm{~Hz}, 1 \mathrm{H}, \mathrm{H}-2 \alpha\right), 4.02(\mathrm{~m}, 1 \mathrm{H}, \mathrm{H}-2 \beta), 4.01\left(\mathrm{td}, J_{4,5 \mathrm{a}}=3.4, J_{3,4}=\right.$ $\left.J_{4,5 \mathrm{~b}}=5.8 \mathrm{~Hz}, 1 \mathrm{H}, \mathrm{H}-4 \beta\right), 3.97\left(\mathrm{t}, J_{2,3}=J_{3,4}=8.0 \mathrm{~Hz}, 1 \mathrm{H}, \mathrm{H}-3 \alpha\right), 3.92\left(\mathrm{dd}, J_{2,3}=3.4, J_{3,4}=5.8 \mathrm{~Hz}\right.$, $1 \mathrm{H}, \mathrm{H}-3 \beta), 3.85\left(\mathrm{td}, J_{4,5 \mathrm{a}}=3.4, J_{3,4}=J_{4,5 \mathrm{~b}}=7.4 \mathrm{~Hz}, 1 \mathrm{H}, \mathrm{H}-4 \alpha\right), 3.78\left(\mathrm{dd}, J_{4,5 \mathrm{a}}=3.4, J_{5 \mathrm{a}, 5 \mathrm{~b}}=12.3 \mathrm{~Hz}\right.$, $1 \mathrm{H}, \mathrm{H}-5 \mathrm{a} \beta$ ), $3.73\left(\mathrm{dd}, J_{4,5 \mathrm{a}}=3.4, J_{5 \mathrm{a}, 5 \mathrm{~b}}=12.2 \mathrm{~Hz}, 1 \mathrm{H}, \mathrm{H}-5 \mathrm{a} \alpha\right), 3.67\left(\mathrm{dd}, J_{4,5 \mathrm{~b}}=5.8, J_{5 \mathrm{a}, 5 \mathrm{~b}}=12.3 \mathrm{~Hz}\right.$, $1 \mathrm{H}, \mathrm{H}-5 \mathrm{~b} \beta$ ), 3.58 (dd, $J_{4,5 \mathrm{~b}}=7.4, J_{5 \mathrm{a}, 5 \mathrm{~b}}=12.2 \mathrm{~Hz}, 1 \mathrm{H}, \mathrm{H}-5 \mathrm{~b} \alpha$ ), 3.39 (s, $3 \mathrm{H}, \beta-\mathrm{OMe}$ ), 3.38 (s, $3 \mathrm{H}, \alpha-$

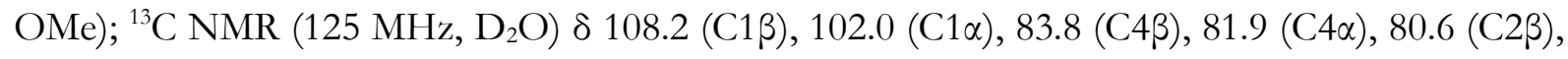

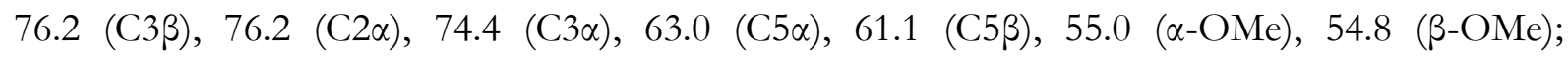
HRMS(ESI) $m / z$ calcd. for $\left[\mathrm{C}_{6} \mathrm{H}_{12} \mathrm{O}_{5}+\mathrm{Na}\right]^{+}: 187.0577$, obsd.: 187.0574 .

\section{General procedure for the synthesis of methyl iodo-glycosides}

The methyl glycoside $(1.00 \mathrm{~g})$ was dissolved in THF $(6.6 \mathrm{mmol} / \mathrm{ml})$, and $\mathrm{PPh}_{3}(1.5$ equiv.) and imidazole (2.0 equiv.) were added. The solution was heated to reflux and a solution of $\mathrm{I}_{2}$ (1.5 equiv.) in THF $(1.6 \mathrm{ml} / \mathrm{mmol})$ was then added dropwise over $15 \mathrm{~min}$, causing imidazolium iodide to form as a white precipitate and colouring the reaction brown. The reaction was kept at reflux until full consumption of starting material was observed and was then allowed to cool to ambient temperature, filtered and concentrated in vacuo. Purification by flash column and reversed phase (HP-20) column chromatography gave the methyl iodo-glycoside as either an oil or a solid.

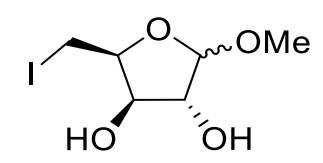

Methyl 5-iodo- $\alpha, \beta$-D-xylofuranoside (80). Subjecting xyloside 79 (2.92 g, $17.8 \mathrm{mmol}$ ) to the general procedure for the synthesis of methyl iodo-glycosides gave xyloside $\mathbf{8 0}$ as a light yellow oil in a 1.3:1 ratio of $\alpha$ - and $\beta$-anomers $(3.01 \mathrm{~g}, 11.0 \mathrm{mmol}, 62 \%) . \mathrm{R}_{f}=0.67$ and 0.63 for $\beta$ and $\alpha$ respectively (EtOAc); $[\alpha]_{D}^{20}=+17.4$ (c =0.63, MeOH); IR (film) 3404, 2932, 2835, 1191, $1080 \mathrm{~cm}^{-1} ;{ }^{1} \mathrm{H}$ NMR $\left(500 \mathrm{MHz}, \mathrm{D}_{2} \mathrm{O}\right) \delta 5.06$ (d, $\left.J_{1,2}=4.4 \mathrm{~Hz}, 1 \mathrm{H}, \mathrm{H}-1 \alpha\right), 4.93(\mathrm{~s}, 1 \mathrm{H}$, 
$\mathrm{H}-1 \beta), 4.58\left(\mathrm{ddd}, J_{3,4}=1.1, J_{4,5 \mathrm{a}}=6.6, J_{4,5 \mathrm{~b}}=7.9 \mathrm{~Hz}, 1 \mathrm{H}, \mathrm{H}-4 \beta\right), 4.43\left(\mathrm{dt}, J_{3,4}=5.6, J_{4,5 \mathrm{a}}=J_{4,5 \mathrm{~b}}=7.5\right.$ $\mathrm{Hz}, 1 \mathrm{H}, \mathrm{H}-4 \alpha), 4.27$ (t, $\left.J_{2,3}=J_{3,4}=4.9 \mathrm{~Hz}, 1 \mathrm{H}, \mathrm{H}-3 \alpha\right), 4.24$ (dd, $\left.J_{2,3}=1.7, J_{3,4}=4.6 \mathrm{~Hz}, 1 \mathrm{H}, \mathrm{H}-3 \beta\right)$, $4.22\left(\mathrm{t}, J_{1,2}=J_{2,3}=4.4 \mathrm{~Hz}, 1 \mathrm{H}, \mathrm{H}-2 \alpha\right), 4.22(\mathrm{~m}, 1 \mathrm{H}, \mathrm{H}-2 \beta), 3.46(\mathrm{~s}, 3 \mathrm{H}, \alpha-\mathrm{OMe}), 3.40(\mathrm{~s}, 3 \mathrm{H}, \beta-$ OMe), 3.39 (m, 1H, H-5aß), 3.36 (dd, $\left.J_{4,5 \mathrm{a}}=6.0, J_{5 \mathrm{a}, 5 \mathrm{~b}}=10.5 \mathrm{~Hz}, 1 \mathrm{H}, \mathrm{H}-5 \mathrm{a} \alpha\right), 3.33$ (dd, $J_{4,5 \mathrm{~b}}=7.9$, $\left.J_{5 a, 5 \mathrm{~b}}=9.9 \mathrm{~Hz}, 1 \mathrm{H}, \mathrm{H}-5 \mathrm{~b} \beta\right), 3,25\left(\mathrm{dd}, J_{4,5 \mathrm{~b}}=7.5, J_{5 a, 5 \mathrm{~b}}=10.5 \mathrm{~Hz}, 1 \mathrm{H}, \mathrm{H}-5 \mathrm{~b} \alpha\right) ;{ }^{13} \mathrm{C} \mathrm{NMR}(125 \mathrm{MHz}$,

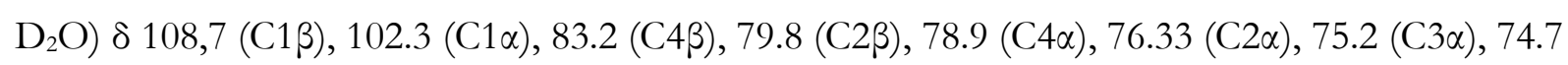

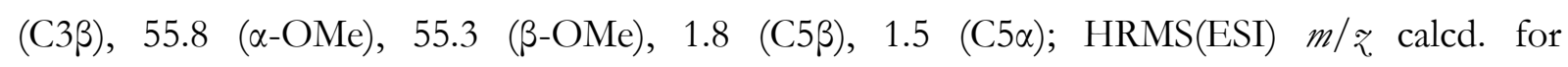
$\left[\mathrm{C}_{6} \mathrm{H}_{11} \mathrm{IO}_{4}+\mathrm{Na}\right]^{+}: 296.9594$, obsd.: 296.9598 .

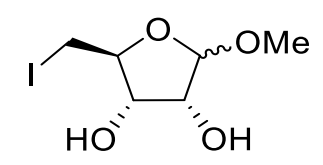

Methyl 5-iodo- $\alpha, \beta$-D-ribofuranoside (112). Subjecting riboside 111 (2.77 $\mathrm{g}, 16.9 \mathrm{mmol}$ ) to the general procedure for the synthesis of methyl iodo-glycosides gave riboside 112 as an amorphous white solid in a 1:7.7 ratio of $\alpha$ - and $\beta$-anomers $(3.02 \mathrm{~g}, 11.0 \mathrm{mmol}, 65 \%)$. $\mathrm{R}_{f}$ $=0.51$ (3:1 EtOAc/Hexane); $[\alpha]_{D}^{20}=-13.9(\mathrm{c}=0.72, \mathrm{MeOH}) ; \mathrm{IR}($ film $) 3372,2948,2829,1187$, $1101 \mathrm{~cm}^{-1} ;{ }^{1} \mathrm{H}$ NMR $\left(500 \mathrm{MHz}, \mathrm{D}_{2} \mathrm{O}\right) \delta 4.90$ (s, $\left.1 \mathrm{H}, \mathrm{H}-1\right), 4.13$ (dd, $J_{2,3}=4.7, J_{3,4}=6.5 \mathrm{~Hz}, 1 \mathrm{H}, \mathrm{H}-$ 3), $4.09\left(\mathrm{~d}, J_{2,3}=4.7 \mathrm{~Hz}, 1 \mathrm{H}, \mathrm{H}-2\right), 3.98\left(\mathrm{q}, J_{4,5 \mathrm{a}}=4.8, J_{4,5 \mathrm{~b}}=6.4, J_{3,4}=6.5, \mathrm{~Hz}, 1 \mathrm{H}, \mathrm{H}-4\right), 3.48(\mathrm{dd}$, $\left.J_{4,5 \mathrm{a}}=4.8, J_{5 \mathrm{a}, 5 \mathrm{~b}}=11.0 \mathrm{~Hz}, 1 \mathrm{H}, \mathrm{H}-5 \mathrm{a}\right), 3.41(\mathrm{~s}, 3 \mathrm{H}, \mathrm{OMe}), 3.36\left(\mathrm{dd}, J_{4,5 \mathrm{~b}}=6.4, J_{5 \mathrm{a}, 5 \mathrm{~b}}=11.0 \mathrm{~Hz}, 1 \mathrm{H}\right.$, $\mathrm{H}-5 \mathrm{~b}) ;{ }^{13} \mathrm{C}$ NMR (125 MHz, D $2 \mathrm{O}$ ) $\delta 107.7$ (C1), 81.5 (C4), 74.6 (C2), 74.2 (C3), 55.2 (OMe), 7.4 (C5); HRMS(ESI) m/ z calcd. for $\left[\mathrm{C}_{6} \mathrm{H}_{11} \mathrm{IO}_{4}+\mathrm{Na}\right]^{+}: 296.9594$, obsd.: 296.9590.

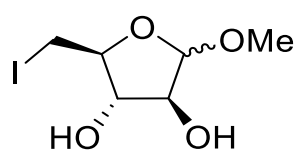

Methyl 5-iodo- $\alpha, \beta$-D-arabinofuranoside (123). Subjecting arabinoside $122(2.8 \mathrm{~g}, 17.1 \mathrm{mmol})$ to the general procedure for the synthesis of methyl iodo-glycosides gave arabinoside 123 as a light yellow oil in a 3:1 ratio of $\alpha$-and $\beta$-anomers (689 mg, $2.51 \mathrm{mmol}, 15 \%$ ). $\mathrm{R}_{f}=0.54$ and 0.47 for $\alpha$ and $\beta$ respectively (3:1 EtOAc/Hexane); $[\alpha]_{D}^{20}=+27.0(\mathrm{c}=0.81, \mathrm{MeOH})$; IR (film) 3381, 2929, 2835, 1190, $1092 \mathrm{~cm}^{-1} ;{ }^{1} \mathrm{H}$ NMR $\left(500 \mathrm{MHz}, \mathrm{D}_{2} \mathrm{O}\right) \delta 4.96\left(\mathrm{~d}, J_{1,2}=1.8 \mathrm{~Hz}, 1 \mathrm{H}\right.$, $\mathrm{H}-1 \alpha), 4.92\left(\mathrm{~d}, J_{1,2}=4.6 \mathrm{~Hz}, 1 \mathrm{H}, \mathrm{H}-1 \beta\right), 4.16\left(\mathrm{dd}, J_{1,2}=4.6, J_{2,3}=7.8 \mathrm{~Hz}, 1 \mathrm{H}, \mathrm{H}-2 \beta\right), 4.12\left(\mathrm{dd}, J_{1,2}\right.$ $\left.=1.8, J_{2,3}=3.5 \mathrm{~Hz}, 1 \mathrm{H}, \mathrm{H}-2 \alpha\right), 4.02\left(\mathrm{dd}, J_{3,4}=4.6, J_{2,3}=7.8 \mathrm{~Hz}, 1 \mathrm{H}, \mathrm{H}-3 \beta\right), 3.97\left(\mathrm{q}, J_{4,5 \mathrm{a}}=J_{4,5 \mathrm{~b}}=\right.$ $\left.4.9, J_{3,4}=5.8 \mathrm{~Hz}, 1 \mathrm{H}, \mathrm{H}-4 \alpha\right), 3.93\left(\mathrm{dd}, J_{2,3}=3.5, J_{3,4}=5.8 \mathrm{~Hz}, 1 \mathrm{H}, \mathrm{H}-3 \alpha\right), 3.93$ (m, $\left.1 \mathrm{H}, \mathrm{H}-4 \beta\right), 3.51$ $\left(\mathrm{dd}, J_{4,5 \mathrm{a}}=4.9, J_{5 \mathrm{a}, 5 \mathrm{~b}}=11.0 \mathrm{~Hz}, 1 \mathrm{H}, \mathrm{H}-5 \mathrm{a} \alpha\right), 3.46\left(\mathrm{dd}, J_{4,5 \mathrm{a}}=5.4, J_{5 \mathrm{a}, 5 \mathrm{~b}}=10.8 \mathrm{~Hz}, 1 \mathrm{H}, \mathrm{H}-5 \mathrm{a} \beta\right), 3.44$ (s, 3H, $\beta$-OMe), 3.42 (s, 3H, $\alpha-\mathrm{OMe}$ ), 3.40 (dd, $\left.J_{4,5 \mathrm{~b}}=4.9, J_{5 a, 5 \mathrm{~b}}=11.0 \mathrm{~Hz}, 1 \mathrm{H}, \mathrm{H}-5 \mathrm{~b} \alpha\right), 3.37$ (m,

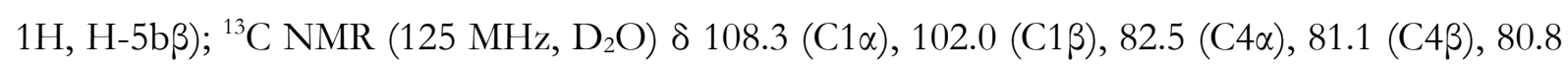

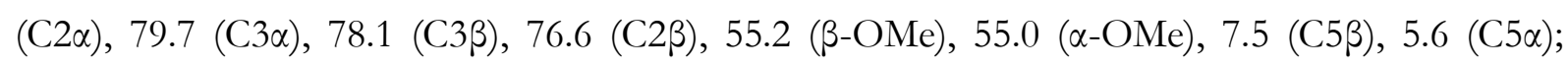
HRMS(ESI) $m / z$ calcd. for $\left[\mathrm{C}_{6} \mathrm{H}_{11} \mathrm{IO}_{4}+\mathrm{Na}\right]^{+}: 296.9594$, obsd.: 296.9592. 


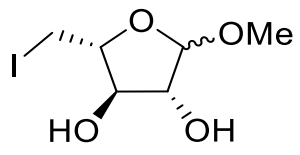

Methyl 5-iodo- $\alpha, \beta$-L-arabinofuranoside (120). Subjecting arabinoside 119 ( $883 \mathrm{mg}, 5.38 \mathrm{mmol}$ ) to the general procedure for the synthesis of methyl iodo-glycosides gave arabinoside 120 as a light yellow oil in a 2:1 ratio of $\alpha$ - and $\beta$-anomers $(1.19 \mathrm{~g}, 4.35 \mathrm{mmol}, 81 \%)$. $\mathrm{R}_{f}$ $=0.57$ and 0.47 for $\beta$ and $\alpha$ respectively $\left(\right.$ EtOAc); $[\alpha]_{D}^{20}=-19.3(\mathrm{c}=1.09, \mathrm{MeOH}) ; \mathrm{IR}$ (film) 3357, 2929, 2833, 1188, $1091 \mathrm{~cm}^{-1}$; ${ }^{1} \mathrm{H}$ NMR (500 MHz, D $\left.2 \mathrm{O}\right) \delta 4.92\left(\mathrm{~d}, J_{1,2}=1.7 \mathrm{~Hz}, 1 \mathrm{H}, \mathrm{H}-1 \alpha\right), 4.88$ $\left(\mathrm{d}, J_{1,2}=4.7 \mathrm{~Hz}, 1 \mathrm{H}, \mathrm{H}-1 \beta\right), 4.13\left(\mathrm{dd}, J_{2,3}=4.7, J_{1,2}=7.8 \mathrm{~Hz}, 1 \mathrm{H}, \mathrm{H}-2 \beta\right), 4.08\left(\mathrm{dd}, J_{1,2}=1.8, J_{2,3}=\right.$ $3.4 \mathrm{~Hz}, 1 \mathrm{H}, \mathrm{H}-2 \alpha), 3.99$ (dd, $\left.J_{2,3}=6.6, J_{3,4}=7.8 \mathrm{~Hz}, 1 \mathrm{H}, \mathrm{H}-3 \beta\right), 3.94$ (q, $J_{4,5}=5.6, J_{3,4}=11.1 \mathrm{~Hz}$, $1 \mathrm{H}, \mathrm{H}-4 \alpha), 3.89$ (dd, $\left.J_{2,3}=3.7, J_{3,4}=5.8 \mathrm{~Hz}, 1 \mathrm{H}, \mathrm{H}-3 \alpha\right), 3.47$ (dd, $J_{4,5 \mathrm{a}}=4.9, J_{5 a, 5 \mathrm{~b}}=11.0 \mathrm{~Hz}, 1 \mathrm{H}$, H-5a $\alpha$ ), 3.38 (s, 3H, $\alpha-\mathrm{OMe}$ ), 3.42 (dd, $J_{4,5 \mathrm{a}}=5.3$, $\left.J_{5 \mathrm{a}, 5 \mathrm{~b}}=10.8 \mathrm{~Hz}, 1 \mathrm{H}, \mathrm{H}-5 \mathrm{a} \beta\right), 3.40$ (s, 3H, $\beta$-OMe), $3.36\left(\mathrm{dd}, J_{4,5 \mathrm{~b}}=6.1, J_{5 a, 5 \mathrm{~b}}=11.2 \mathrm{~Hz}, 1 \mathrm{H}, \mathrm{H}-5 \mathrm{~b} \alpha\right), 3.33\left(\mathrm{dd}, J_{4,5 \mathrm{~b}}=7.0, J_{5 a, 5 \mathrm{~b}}=10.7 \mathrm{~Hz}\right) ;{ }^{13} \mathrm{C} \mathrm{NMR}$

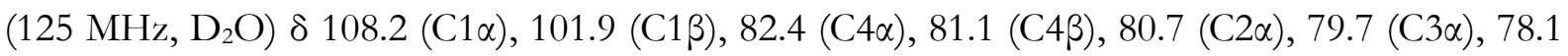

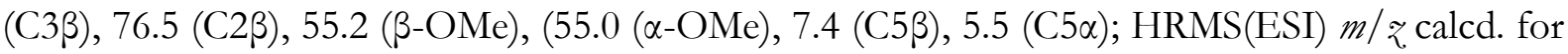
$\left[\mathrm{C}_{6} \mathrm{H}_{11} \mathrm{IO}_{4}+\mathrm{Na}\right]^{+}$: 296.9594, obsd.: 296.9588 .

\section{General procedure for the synthesis of azasugars from methyl iodo-glycosides}

The methyl iodo-glycoside (100 mg) was dissolved in $\mathrm{HCl}$ (aq. $0.1 \mathrm{M}, 10 \mathrm{ml} / \mathrm{mmol}$ ), and refluxed until full consumption of starting material was observed. The reaction was then allowed to cool to ambient, and the amine ( 3 equiv., or $5 \mathrm{ml} / \mathrm{mmol}$ of $\mathrm{NH}_{3}$ (aq. $28 \% \mathrm{w} / \mathrm{w}$ )) followed by $\mathrm{NaBH}_{3} \mathrm{CN}$ (4 equiv.) were added, and the reaction was left to stir for $19 \mathrm{~h}$. The reaction was then concentrated in vacuo and purified on Dowex $\left(\mathrm{H}^{+}\right)$and flash column chromatography, giving the azasugar as an amorphous white solid.<smiles>OC1[C@@H](O)CNC[C@H]1O</smiles>

(3R,4r,5S)-piperidine-3,4,5-triol (30). Subjecting xyloside 80 (86.5 mg, $0.32 \mathrm{mmol}$ ) to the general procedure for the synthesis of azasugars from methyl iodo-glycosides using $\mathrm{NH}_{3}(5 \mathrm{ml} / \mathrm{mmol}$, aq. 28\% w/w) gave azasugar 30 as an amorphous white solid $(32.7 \mathrm{mg}$, $0.25 \mathrm{mmol}, 77 \%) . \mathrm{R}_{f}=0.25\left(\mathrm{DCM} / \mathrm{EtOH} / \mathrm{MeOH} / 28 \%\right.$ aq. $\left.\mathrm{NH}_{3}, 5 / 2 / 2 / 1, \mathrm{v} / \mathrm{v} / \mathrm{v} / \mathrm{v}\right) ; \mathrm{IR}$ (film) $3362,3217,3038,1629,1438,1081 \mathrm{~cm}^{-1} ;{ }^{1} \mathrm{H} \operatorname{NMR}\left(500 \mathrm{MHz}, \mathrm{D}_{2} \mathrm{O}\right) \delta 3.79\left(\mathrm{ddd}, J_{1 \mathrm{a}, 2}=1.4, J_{2,3}=\right.$ 4.6, $\left.J_{1 \mathrm{~b}, 2}=9.4 \mathrm{~Hz}, 2 \mathrm{H}, \mathrm{H}-2, \mathrm{H}-4\right), 3.53\left(\mathrm{t}, J_{1,2}=J_{2,3}=8.5 \mathrm{~Hz}, 1 \mathrm{H}, \mathrm{H}-3\right), 3.47$ (dd, $J_{1 \mathrm{a}, 2}=4.7, J_{1 \mathrm{a}, 1 \mathrm{~b}}=$ $12.7 \mathrm{~Hz}, 2 \mathrm{H}, \mathrm{H}-1 \mathrm{a}, \mathrm{H}-5 \mathrm{a}), 2.95$ (dd, $\left.J_{1 \mathrm{a}, 1 \mathrm{~b}}=10.5, J_{1 \mathrm{~b}, 2}=12.5 \mathrm{~Hz}, 2 \mathrm{H}, \mathrm{H}-1 \mathrm{~b}, \mathrm{H}-5 \mathrm{~b}\right) ;{ }^{13} \mathrm{C}$ NMR (125 
$\left.\mathrm{MHz}, \mathrm{D}_{2} \mathrm{O}\right) \delta 76.2$ (C3), 68.6 (C2, C4), 47.4 (C1, C5); HRMS(ESI) $\mathrm{m} /$ z calcd. for $\left[\mathrm{C}_{5} \mathrm{H}_{12} \mathrm{NO}_{3}\right]^{+}$: 134.0812, obsd.: 134.0814 .<smiles>O[C@H]1CN(Cc2ccccc2)C[C@@H](O)[C@@H]1O</smiles>

(3R,4r,5S)-1-benzylpiperidine-3,4,5-triol (101). Subjecting xyloside 80 $(184 \mathrm{mg}, 0.67 \mathrm{mmol})$ to the general procedure for the synthesis of azasugars from methyl iodoglycosides using benzylamine (3 equiv.) gave azasugar 101 as an amorphous white solid $(57.6 \mathrm{mg}$, $0.26 \mathrm{mmol}, 39 \%) \cdot \mathrm{R}_{f}=0.34\left(\mathrm{DCM} / \mathrm{EtOH} / \mathrm{MeOH} / 28 \%\right.$ aq. $\left.\mathrm{NH}_{3}, 15 / 2 / 2 / 1, \mathrm{v} / \mathrm{v} / \mathrm{v} / \mathrm{v}\right) ; \mathrm{IR}$ (film) 3326, 3221, 3059, 2911, 1457, 1369, $1022 \mathrm{~cm}^{-1} ;{ }^{1} \mathrm{H}$ NMR (500 MHz, $\left.\mathrm{D}_{2} \mathrm{O}\right) \delta$ 7.44-7.33 (m, 5H, Ar), $3.63\left(\mathrm{~s}, 2 \mathrm{H}, \mathrm{CH}_{2} \mathrm{Bn}\right), 3.54\left(\mathrm{ddd}, J_{1 \mathrm{a}, 2}=1.3, J_{2,3}=4.8, J_{1 \mathrm{~b}, 2}=9.9 \mathrm{~Hz}, 2 \mathrm{H}, \mathrm{H}-2\right), 3.17$ (t, $J_{1,2}=J_{2,3}=9.2$ $\mathrm{Hz}, 1 \mathrm{H}, \mathrm{H}-3), 3.00$ (dd, $\left.J_{1 \mathrm{a}, 2}=1.6, J_{1 \mathrm{a}, 1 \mathrm{~b}}=11.2 \mathrm{~Hz}, 2 \mathrm{H}, \mathrm{H}-1 \mathrm{a}, \mathrm{H}-5 \mathrm{a}\right), 2.04\left(\mathrm{t}, J_{1 \mathrm{a}, 1 \mathrm{~b}}=J_{1,2}=11.2 \mathrm{~Hz}\right.$, 2H, H-1b, H-5b). ${ }^{13} \mathrm{C}$ NMR (125 MHz, $\left.\mathrm{D}_{2} \mathrm{O}\right) \delta 135.4$ (C $\mathrm{C}_{\mathrm{q}}$ aromatic), 130.2, 128.5, 127.9 (Caromatics), 78.2 (C3), 69.3 (C2, C4), 61.0 ( $\left.\mathrm{CH}_{2} \mathrm{Bn}\right), 56.4$ (C1, C5); HRMS(ESI) m/z calcd. for $\left[\mathrm{C}_{12} \mathrm{H}_{18} \mathrm{NO}_{3}\right]^{+}:$224.1281, obsd.: 224.1281.<smiles>O[C@H]1CN(CCc2ccccc2)C[C@@H](O)[C@H]1O</smiles>

(3R,4r,5S)-1-(2-phenylethyl)piperidine-3,4,5-triol (102). Subjecting xyloside $80(217 \mathrm{mg}, 0.79 \mathrm{mmol})$ to the general procedure for the synthesis of azasugars from methyl iodo-glycosides using 2-phenylethylamine (3 equiv.) gave azasugar 102 as an amorphous white solid (88.7 mg, $0.37 \mathrm{mmol}, 47 \%)$. $\mathrm{R}_{f}=0.51$ (DCM/EtOH/MeOH/28\% aq. $\mathrm{NH}_{3}, 15 / 2 / 2 / 1$, $\mathrm{v} / \mathrm{v} / \mathrm{v} / \mathrm{v})$; IR (film) 3338, 3220, 3063, 3022, 2912, 1496, 1394, $1023 \mathrm{~cm}^{-1} ;{ }^{1} \mathrm{H}$ NMR (500 MHz, $\left.\mathrm{D}_{2} \mathrm{O}\right) \delta 7.37-7.23(\mathrm{~m}, 5 \mathrm{H}, \mathrm{Ar}), 3.54\left(\mathrm{ddd}, J_{1 \mathrm{a}, 2}=4.7, J_{2,3}=4.8, J_{1 \mathrm{~b}, 2}=10.0 \mathrm{~Hz}, 2 \mathrm{H}, \mathrm{H}-2, \mathrm{H}-4\right), 3.20$ $\left(\mathrm{t}, J_{2,3}=J_{3,4}=9.2 \mathrm{~Hz}, 1 \mathrm{H}, \mathrm{H}-3\right), 3.09\left(\mathrm{dd}, J_{1 \mathrm{a}, 2}=4.6, J_{1 \mathrm{a}, 1 \mathrm{~b}}=11.1 \mathrm{~Hz}, 2 \mathrm{H}, \mathrm{H}-1 \mathrm{a}, \mathrm{H}-5 \mathrm{a}\right), 2.81(\mathrm{~m}, 2 \mathrm{H}$, $\mathrm{N}-\mathrm{CH}_{2} \underline{\mathrm{CH}}_{2} \mathrm{Ar}$ ), 2.69 (m, 2H, N-C $\underline{\mathrm{H}}_{2} \mathrm{CH}_{2} \mathrm{Ar}$ ), 2.09 (t, $J_{1 \mathrm{a}, 1 \mathrm{~b}}=J_{1,2}=11.1 \mathrm{~Hz}, 2 \mathrm{H}, \mathrm{H}-1 \mathrm{~b}, \mathrm{H}-5 \mathrm{~b}$ ); ${ }^{13} \mathrm{C}$ NMR (125 MHz, D $2 \mathrm{O}) \delta 139.8$ (C $\mathrm{C}_{\mathrm{q}}$ aromatic), 128.7, 126.3 (C-aromatics), 78.2 (C3), 69.4 (C2, C4), $58.4\left(\mathrm{~N}-\underline{C H}_{2} \mathrm{CH}_{2} \mathrm{Ar}\right), 56.7$ (C1, C5), $31.9\left(\mathrm{~N}-\mathrm{CH}_{2} \underline{\mathrm{CH}}_{2} \mathrm{Ar}\right)$; HRMS(ESI) m/z calcd. for $\left[\mathrm{C}_{13} \mathrm{H}_{20} \mathrm{NO}_{3}\right]^{+}$: 238.1438, obsd.: 238.1439. 


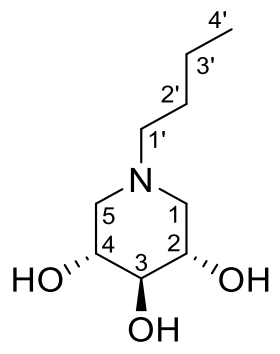

(3R,4r,5S)-1-butylpiperidine-3,4,5-triol (103). Subjecting xyloside 80 (183 $\mathrm{mg}, 0.68 \mathrm{mmol})$ to the general procedure for the synthesis of azasugars from methyl iodoglycosides using $n$-butylamine (3 equiv.) gave azasugar 103 as an amorphous white solid $(70.2 \mathrm{mg}$, $0.37 \mathrm{mmol}, 55 \%) \cdot \mathrm{R}_{f}=0.45$ (DCM/EtOH/MeOH/28\% aq. $\mathrm{NH}_{3}, 15 / 2 / 2 / 1, \mathrm{v} / \mathrm{v} / \mathrm{v} / \mathrm{v}$ ); IR (film) 3327, 3198, 2962, 2921, 2871, 2812, 1368, $1023 \mathrm{~cm}^{-1} ;{ }^{1} \mathrm{H}$ NMR $\left(500 \mathrm{MHz}, \mathrm{D}_{2} \mathrm{O}\right) \delta 3.53$ (ddd, $J_{1 \mathrm{a}, 2}$ $\left.=1.3, J_{2,3}=4.8, J_{1 \mathrm{~b}, 2}=10.0 \mathrm{~Hz}, 2 \mathrm{H}, \mathrm{H}-2, \mathrm{H}-4\right), 3.20$ (t, $\left.J_{2,3}=J_{3,4}=9.2 \mathrm{~Hz}, 1 \mathrm{H}, \mathrm{H}-3\right), 3.04$ (dd, $J_{1 \mathrm{a}, 2}$ $\left.=5.0, J_{1 \mathrm{a}, 1 \mathrm{~b}}=11.3 \mathrm{~Hz}, 2 \mathrm{H}, \mathrm{H}-1 \mathrm{a}, \mathrm{H}-5 \mathrm{a}\right), 2.44\left(\mathrm{~m}, 2 \mathrm{H}, \mathrm{H}-1^{\prime}\right) 2.01$ (t, $J_{1 \mathrm{a}, 1 \mathrm{~b}}=J_{1,2}=11.2 \mathrm{~Hz}, 2 \mathrm{H}, \mathrm{H}-$ 1b, H-5b) 1.45 (tt, 2H, H-2') 1.27 (sex, 2H, H-3') 0.87 (t, $\left.J_{3 \mathrm{a}, 4}=J_{3 \mathrm{~b}, 4}=7.4 \mathrm{~Hz}, 3 \mathrm{H}, \mathrm{H}-4^{\prime}\right) ;{ }^{13} \mathrm{C}$ NMR (125 MHz, $\left.\mathrm{D}_{2} \mathrm{O}\right) \delta 78.2$ (C3), 69.3 (C2, C4), 56.7 (C1’) 56.7 (C1, C5) 27.6 (C2’) 20.0 (C3’) 13.1 (C4'); HRMS(ESI) m/ z calcd. for $\left[\mathrm{C}_{9} \mathrm{H}_{20} \mathrm{NO}_{3}\right]^{+}:$190.1438, obsd.: 190.1440.<smiles>C#CCN1C[C@H](O)[C@H](O)[C@H](O)C1</smiles>

(3R,4r,5S)-1-propargylpiperidine-3,4,5-triol (104). Subjecting xyloside 80 (216 $\mathrm{mg}, 0.79 \mathrm{mmol})$ to the general procedure for the synthesis of azasugars from methyl iodoglycosides using propargylamine (3 equiv.) gave azasugar 104 as an amorphous white solid (81 mg, $0.47 \mathrm{mmol}, 60 \%) . \mathrm{R}_{f}=0.23\left(\mathrm{DCM} / \mathrm{EtOH} / \mathrm{MeOH} / 28 \%\right.$ aq. $\left.\mathrm{NH}_{3}, 15 / 2 / 2 / 1, \mathrm{v} / \mathrm{v} / \mathrm{v} / \mathrm{v}\right) ; \mathrm{IR}$ (film) 3288, 2912, 2826, 1433, $1011 \mathrm{~cm}^{-1} ;{ }^{1} \mathrm{H}$ NMR $\left(500 \mathrm{MHz}, \mathrm{D}_{2} \mathrm{O}\right) \delta 3.56\left(\mathrm{ddd}, J_{1 \mathrm{a}, 2}=1.5, J_{2,3}=4.8, J_{1 \mathrm{~b}, 2}\right.$ $=10.1 \mathrm{~Hz} 2 \mathrm{H}, \mathrm{H}-2, \mathrm{H}-4), 3.36$ (s, 2H, $\mathrm{CH}_{2}$-alkyne), 3.21 (t, $\left.J_{2,3}=J_{3,4}=9.2 \mathrm{~Hz}, 1 \mathrm{H}, \mathrm{H}-3\right), 3.04$ (dd, $\left.J_{1 \mathrm{a}, 2}=4.9, J_{1 \mathrm{a}, 1 \mathrm{~b}}=11.0 \mathrm{~Hz}, 2 \mathrm{H}, \mathrm{H}-1 \mathrm{a}, \mathrm{H}-5 \mathrm{a}\right), 2.23$ (t, $\left.J_{1 \mathrm{a}, 1 b}=J_{1,2}=11.0 \mathrm{~Hz}, 2 \mathrm{H}, \mathrm{H}-1 \mathrm{~b}, \mathrm{H}-5 \mathrm{~b}\right) ;{ }^{13} \mathrm{C}$ NMR (150 MHz, D $2 \mathrm{O}$ ) $\delta 77.9$ (C3), 75.0 (C $\mathrm{C}_{\mathrm{q}}$ alkyne), 71.7 (CH-alkyne), 69.4 (C2, C4), 55.7 (C1, C5), 45.1 ( $\mathrm{CH}_{2}$-alkyne); HRMS(ESI) m/z calcd. for $\left[\mathrm{C}_{8} \mathrm{H}_{14} \mathrm{NO}_{3}\right]^{+}: 172.0968$, obsd.: 172.0962.<smiles>OCCN1C[C@H](O)[C@H](O)[C@H](O)C1</smiles>

(3R,4s,5S)-1-(2-hydroxyethyl)piperidine-3,4,5-triol (105). Subjecting xyloside 80 ( $97.6 \mathrm{mg}, 0.36 \mathrm{mmol})$ to the general procedure for the synthesis of azasugars from methyl iodo-glycosides using ethanolamine (3 equiv.) gave azasugar 105 as an amorphous white 
solid (45.4 mg, $0.26 \mathrm{mmol}, 71 \%) . \mathrm{R}_{f}=0.27$ (DCM/EtOH/MeOH/28\% aq. $\mathrm{NH}_{3}, 5 / 2 / 2 / 1$, v/v/v/v); IR (film) 3354, 3226, 2926, 1635, 1438, $1018 \mathrm{~cm}^{-1} ;{ }^{1} \mathrm{H}$ NMR (500 MHz, $\left.\mathrm{D}_{2} \mathrm{O}\right) \delta 3.93$ (t, $J_{\text {ethyl }}=5.2 \mathrm{~Hz}, 2 \mathrm{H}, \mathrm{N}-\underline{\mathrm{C}}_{2} \mathrm{CH}_{2} \mathrm{OH}$ ), 3.85 (br td, 2H, H-2, H-4), 3.64 (br dd, 2H, H-1a, H-5a), 3.52 (br t, 1H, H-3), 3.37 (t, Jethyl $5.2 \mathrm{~Hz}, 2 \mathrm{H}, \mathrm{N}-\mathrm{CH}_{2} \mathrm{CH}_{2} \mathrm{OH}$ ), 3.02 (br t, 2H, H-1b, H-5b); ${ }^{13} \mathrm{C}$ NMR $\left(150 \mathrm{MHz}, \mathrm{D}_{2} \mathrm{O}\right) \delta 75.9(\mathrm{C} 3), 66.5$ (C2, C4), $58.4\left(\mathrm{~N}-\underline{C H}_{2} \mathrm{CH}_{2}-\mathrm{OH}\right), 55.1\left(\mathrm{~N}-\mathrm{CH}_{2} \mathrm{CH}_{2}-\mathrm{OH}\right), 54.3$ (C1,C5); HRMS(ESI) m/z calcd. for $\left[\mathrm{C}_{7} \mathrm{H}_{16} \mathrm{NO}_{4}\right]^{+}:$178.1074, obsd.: 178.1072.<smiles>O[C@H]1CNC[C@@H](O)[C@@H]1O</smiles>

(3R,4s,5S)-piperidine-3,4,5-triol (31). Subjecting riboside 112 (96.7 mg, $0.35 \mathrm{mmol}$ ) to the general procedure for the synthesis of azasugars from methyl iodo-glycosides using $\mathrm{NH}_{3}(5 \mathrm{ml} / \mathrm{mmol}$, aq. $28 \% \mathrm{w} / \mathrm{w})$ gave azasugar 31 as an amorphous white solid (41.7 $\mathrm{mg}$, $0.31 \mathrm{mmol}, 89 \%) . \mathrm{R}_{f}=0.17$ (DCM/EtOH $/ \mathrm{MeOH} / 28 \%$ aq. $\left.\mathrm{NH}_{3}, 5 / 2 / 2 / 1, \mathrm{v} / \mathrm{v} / \mathrm{v} / \mathrm{v}\right) ; \mathrm{IR}$ (film) 3217, 3038, 2865, 1631, 1445, $1093 \mathrm{~cm}^{-1} ;{ }^{1} \mathrm{H}$ NMR (500 MHz, D $\left.2 \mathrm{O}\right) \delta 4.08$ (br ddd, 2H, H-2, H4), 4.05 (br t, 1H, H-3), 3.24 (m, 4H, H-1, H-5); ${ }^{13} \mathrm{C}$ NMR (125 MHz, $\left.\mathrm{D}_{2} \mathrm{O}\right) \delta 68.2$ (C3), 65.4 (C2, C4), 44.3 (C1, C5); HRMS(ESI) m/ z calcd. for $\left[\mathrm{C}_{5} \mathrm{H}_{12} \mathrm{NO}_{3}\right]^{+}:$134.0812, obsd.: 134.0806.

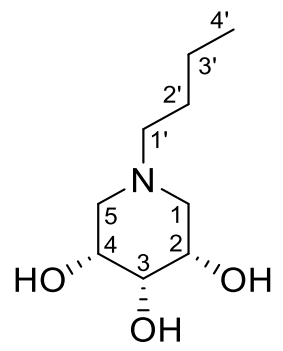

(3R,4s,5S)-1-butylpiperidine-3,4,5-triol (45). Subjecting riboside 112 ( $98.1 \mathrm{mg}, 0.36 \mathrm{mmol}$ ) to the general procedure for the synthesis of azasugars from methyl iodoglycosides using $n$-butylamine (3 equiv.) gave azasugar 45 as an amorphous white solid in (42.1 mg, $0.22 \mathrm{mmol}, 62 \%) \cdot \mathrm{R}_{f}=0.45$ (DCM/EtOH/MeOH/28\% aq. $\mathrm{NH}_{3}, 15 / 2 / 2 / 1, \mathrm{v} / \mathrm{v} / \mathrm{v} / \mathrm{v}$ ); IR (film) 3312, 3238, 2956, 2929, 2870, 2830, 1458, $1039 \mathrm{~cm}^{-1}$; ${ }^{1} \mathrm{H}$ NMR $\left(500 \mathrm{MHz}, \mathrm{D}_{2} \mathrm{O}\right) \delta 3.97$ (br t, $1 \mathrm{H}$, H-3), $3.73\left(\mathrm{dt}, J_{1 \mathrm{a}, 2}=J_{1 \mathrm{~b}, 2}=3.4 \mathrm{~Hz}, J_{2,3}=10.2 \mathrm{~Hz}, 2 \mathrm{H}, \mathrm{H}-2, \mathrm{H}-4\right), 2.69$ (br d, $J_{1,2}=9.0 \mathrm{~Hz}, 2 \mathrm{H}, \mathrm{H}-$ 1a, H-5a), 2.43 (m, 2H, H-1'), 2.22 (t, 2H, H-1b, H-5b), 1.45 (tt, 2H, H-2'), 1.26 (sex, 2H, H-3'), $0.86\left(\mathrm{t}, J_{3 \mathrm{a}, 4}=J_{3 \mathrm{~b}, 4}=7.4 \mathrm{~Hz}, 3 \mathrm{H}, \mathrm{H}-4^{\prime}\right) ;{ }^{13} \mathrm{C}$ NMR $\left(150 \mathrm{MHz}, \mathrm{D}_{2} \mathrm{O}\right) \delta 70.0$ (C3), 67.0 (C2, C4), 56.9 (C1’), 51.4 (C1, C5), 27.4 (C2'), 20.0 (C3’), 13.1 (C4'); HRMS(ESI) m/z calcd. for $\left[\mathrm{C}_{9} \mathrm{H}_{20} \mathrm{NO}_{3}\right]^{+}$: 190.1438, obsd.: 190.1442 . 
<smiles>O[C@H]1CN(CCc2ccccc2)C[C@@H](O)[C@H]1O</smiles>

(3R,4s,5S)-1-(2-phenylethyl)piperidine-3,4,5-triol (113). Subjecting riboside $112(98.0 \mathrm{mg}, 0.36 \mathrm{mmol})$ to the general procedure for the synthesis of azasugars from methyl iodo-glycosides using 2-phenylethylamine gave azasugar $\mathbf{1 1 3}$ as an amorphous white solid in (57.1 mg, $0.24 \mathrm{mmol}, 67 \%) . \mathrm{R}_{f}=0.67$ (DCM/EtOH/MeOH/28\% aq. $\mathrm{NH}_{3}, 15 / 2 / 2 / 1$, v/v/v/v); IR (film) 3337, 2934, 2828, 1453, $1024 \mathrm{~cm}^{-1} ;{ }^{1} \mathrm{H}$ NMR $\left(500 \mathrm{MHz}, \mathrm{D}_{2} \mathrm{O}\right) \delta$ 7.36-7.21 (m, 5H, Ar), 3.97 (br t, 1H, H-3), 3.54 (br dt, J=10.3 Hz, 2H, H-2, H-4), 2.78 (m, 2H, N-CH $\mathrm{CH}_{2} \mathrm{Ar}$ ), 2.73 (br dd, 2H, H-1a, H-5a), 2.65 (m, 2H, N-C $\underline{\mathrm{H}}_{2} \mathrm{CH}_{2} \mathrm{Ar}$ ) 2.31 (br t, $2 \mathrm{H}, \mathrm{H}-1 \mathrm{~b}, \mathrm{H}-5 \mathrm{~b}$ ); ${ }^{13} \mathrm{C}$ NMR (125 MHz, $\left.\mathrm{D}_{2} \mathrm{O}\right) \delta 139.3$ (C $\mathrm{C}_{\mathrm{q}}$ Aromatics), 128.7, 128.6, 126.3 (C-Aromatics) 70.0 (C3), 67.1 (C2, C4), $58.6\left(\mathrm{~N}-\underline{C H}_{2} \mathrm{CH}_{2} \mathrm{Ar}\right) 51.3$ (C1, C5) $31.7\left(\mathrm{~N}-\mathrm{CH}_{2} \underline{\mathrm{C}} \mathrm{H}_{2} \mathrm{Ar}\right) ; \mathrm{HRMS}(\mathrm{ESI}) \mathrm{m} / \mathrm{z}$ calcd. for $\left[\mathrm{C}_{13} \mathrm{H}_{20} \mathrm{NO}_{3}\right]^{+}$: 238.1438, obsd.: 238.1442 .<smiles>C#CCN1C[C@H](O)[C@H](O)[C@H](O)C1</smiles>

(3R,4s,5S)-1-propargylpiperidine-3,4,5-triol (114). Subjecting riboside $112(103 \mathrm{mg}, 0.38 \mathrm{mmol})$ to the general procedure for the synthesis of azasugars from methyl iodoglycosides using propargylamine gave azasugar 114 as an amorphous white solid (38.9 $\mathrm{mg}, 0.23$ mmol, 60\%). $\mathrm{R}_{f}=0.32$ (DCM/EtOH/MeOH/28\% aq. $\left.\mathrm{NH}_{3}, 15 / 2 / 2 / 1, \mathrm{v} / \mathrm{v} / \mathrm{v} / \mathrm{v}\right) ; \mathrm{IR}$ (film) 3283, 2927, 2838, 2122, 1430, $1040 \mathrm{~cm}^{-1}$; ${ }^{1} \mathrm{H}$ NMR (500 MHz, D 2 ) $\delta 3.95$ (br t, 1H, H-3), 3.76 (br dt,

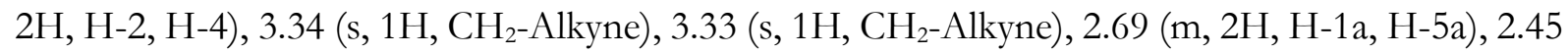
(br t, 2H, H-1b, H-5b), 2.18 (s, 1H, CH-Alkyne); ${ }^{13} \mathrm{C}$ NMR (125 MHz, $\left.\mathrm{D}_{2} \mathrm{O}\right) \delta 77.6$ (C alkyne), 74.7 (CH alkyne), 69.7 (C3), 67.3 (C2, C4), 50.6 (C1, C5), 45.2 ( $\mathrm{CH}_{2}$ Alkyne); HRMS(ESI) m/z. calcd. for $\left[\mathrm{C}_{8} \mathrm{H}_{14} \mathrm{NO}_{3}\right]^{+}:$172.0968, obsd.: 172.0981 .<smiles>OCCN1C[C@H](O)[C@H](O)[C@H](O)C1</smiles>

(3R,4s,5S)-1-(2-hydroxyethyl)piperidine-3,4,5-triol (115). Subjecting riboside 112 (104 mg, $0.38 \mathrm{mmol}$ ) to the general procedure for the synthesis of azasugars from 
methyl iodo-glycosides using ethanolamine (3 equiv.) gave azasugar 115 as an amorphous white solid (48.5 mg, $0.27 \mathrm{mmol}, 72 \%$ ). $\mathrm{R}_{f}=0.48$ (DCM/EtOH/MeOH/28\% aq. $\mathrm{NH}_{3}, 5 / 2 / 2 / 1$, v/v/v/v); IR (film) 3281, 2927, 2833, 1467, 1408, $1031 \mathrm{~cm}^{-1} ;{ }^{1} \mathrm{H}$ NMR $\left(500 \mathrm{MHz}, \mathrm{D}_{2} \mathrm{O}\right) \delta 3.98$ (br t, 1H, H-3), 3.78 (br dt, 2H, H-2, H-4), 3.73 (t, $J_{1,2 \mathrm{a}}=J_{1,2 \mathrm{~b}}=6.0 \mathrm{~Hz}, 2 \mathrm{H}, \mathrm{N}-\mathrm{CH}_{2} \mathrm{CH}_{2} \mathrm{OH}$ ), 2.77 (br dd, 2H, H-1a, H-5a), 2.70 (br t, $2 \mathrm{H}, \mathrm{N}-\mathrm{CH}_{2} \mathrm{CH}_{2} \mathrm{OH}$ ), 2.41 (br t, 2H, H-1b, H-5b); ${ }^{13} \mathrm{C}$ NMR (150 $\left.\mathrm{MHz}, \mathrm{D}_{2} \mathrm{O}\right) \delta 69.8$ (C3), 66.9 (C2,C4), $58.1\left(\mathrm{~N}-\underline{\mathrm{CH}}_{2} \mathrm{CH}_{2} \mathrm{OH}\right), 57.7$ ( $\left.\mathrm{N}^{-\mathrm{CH}_{2}} \underline{\mathrm{CH}}{ }_{2} \mathrm{OH}\right), 51.7$ (C1,C5); HRMS(ESI) $m /$ z calcd. for $\left[\mathrm{C}_{7} \mathrm{H}_{16} \mathrm{NO}_{4}\right]^{+}:$178.1074, obsd.: 178.1073.<smiles>O[C@H]1CNC[C@@H](O)[C@@H]1O</smiles>

(3S,5S)-piperidine-3,4,5-triol (33). Subjecting arabinoside 120 (93.2 mg, $0.34 \mathrm{mmol}$ ) to the general procedure for the synthesis of azasugars from methyl iodo-glycosides using $\mathrm{NH}_{3}(5 \mathrm{ml} / \mathrm{mmol}$, aq. $28 \% \mathrm{w} / \mathrm{w})$ gave azasugar 33 as an amorphous white solid (41.6 mg, $0.31 \mathrm{mmol}, 92 \%) . \mathrm{R}_{f}=0.22\left(\mathrm{DCM} / \mathrm{EtOH} / \mathrm{MeOH} / 28 \%\right.$ aq. $\left.\mathrm{NH}_{3}, 5 / 2 / 2 / 1, \mathrm{v} / \mathrm{v} / \mathrm{v} / \mathrm{v}\right) ;[\alpha]_{D}^{20}=$ +6.1 (c = 0.33, MeOH); IR (film) 3357, 3214, 2946, 1629, 1437, $1085 \mathrm{~cm}^{-1} ;{ }^{1} \mathrm{H}$ NMR (500 MHz, $\left.\mathrm{D}_{2} \mathrm{O}\right) \delta 4.25\left(\mathrm{dt}, J_{3,4}=2.9, J_{4,5 \mathrm{a}}=J_{4,5 \mathrm{~b}}=5.9 \mathrm{~Hz}, 1 \mathrm{H}, \mathrm{H}-4\right), 4.10\left(\mathrm{td}, J_{1 \mathrm{a}, 2}=J_{1 \mathrm{~b}, 2}=4.1, J_{2,3}=8.2 \mathrm{~Hz}\right.$, $1 \mathrm{H}, \mathrm{H}-2), 3.79\left(\mathrm{dd}, J_{3,4}=2.8, J_{2,3}=8.0 \mathrm{~Hz}, 1 \mathrm{H}, \mathrm{H}-3\right), 3.43\left(\mathrm{ddd}, J_{1 \mathrm{a}, \mathrm{NH}}=1.2, J_{1 \mathrm{a}, 2}=4.1, J_{1 \mathrm{a}, 1 \mathrm{~b}}=12.8\right.$ $\mathrm{Hz}, 1 \mathrm{H}, \mathrm{H}-1 \mathrm{a}), 3.31\left(\mathrm{ddd}, J_{5 \mathrm{a}, \mathrm{NH}}=1.2, J_{4,5 \mathrm{a}}=5.9, J_{5 \mathrm{a}, 5 \mathrm{~b}}=13.0 \mathrm{~Hz}, 1 \mathrm{H}, \mathrm{H}-5 \mathrm{a}\right), 3.23\left(\mathrm{dd}, J_{4,5 \mathrm{~b}}=2.8\right.$, $\left.J_{5 a, 5 \mathrm{~b}}=13.0 \mathrm{~Hz}, 1 \mathrm{H}, \mathrm{H}-5 \mathrm{~b}\right), 2.97\left(\mathrm{dd}, J_{1 \mathrm{~b}, 2}=8.5, J_{1 \mathrm{a}, 1 \mathrm{~b}}=12.8 \mathrm{~Hz}, 1 \mathrm{H}, \mathrm{H}-1 \mathrm{~b}\right) ;{ }^{13} \mathrm{C} \mathrm{NMR}(125 \mathrm{MHz}$, $\left.\mathrm{D}_{2} \mathrm{O}\right) \quad \delta 70.8$ (C3), 65.0 (C2), 64.7 (C4), 46.0 (C5), 45.5 (C1); HRMS(ESI) m/z. calcd. for $\left[\mathrm{C}_{5} \mathrm{H}_{12} \mathrm{NO}_{3}\right]^{+}: 134.0812$, obsd.: 134.0808 .<smiles>O[C@H]1CN(CCc2ccccc2)C[C@@H](O)[C@H]1O</smiles>

(3S,5S)-1-(2-phenylethyl)piperidine-3,4,5-triol (121). Subjecting arabinoside 120 (96.4 $\mathrm{mg}, 0.35 \mathrm{mmol}$ ) to the general procedure for the synthesis of azasugars from methyl iodo-glycosides using 2-phenylethylamine (3 equiv.) gave azasugar 121 as an amorphous white solid (39.1 mg, $0.16 \mathrm{mmol}, 47 \%) . \mathrm{R}_{f}=0.53$ (DCM/EtOH/MeOH/28\% aq. $\mathrm{NH}_{3}, 5 / 2 / 2 / 1$, $\mathrm{v} / \mathrm{v} / \mathrm{v} / \mathrm{v}) ;[\alpha]_{D}^{20}=+24.3(\mathrm{c}=0.25, \mathrm{MeOH}) ; \mathrm{IR}($ film) 3359, 3244, 2930, 2822, 1453, 1336, 1081 $\mathrm{cm}^{-1} ;{ }^{1} \mathrm{H}$ NMR $\left(500 \mathrm{MHz}, \mathrm{D}_{2} \mathrm{O}\right) \delta$ 7.39-7.35 (m, 5H, Ar), 4.01 (m, 1H, H-4), $3.87\left(\mathrm{td}, J_{1 \mathrm{a}, 2}=J_{1 \mathrm{~b}, 2}=\right.$ 4.3, $\left.J_{2,3}=8.9 \mathrm{~Hz}, 1 \mathrm{H}, \mathrm{H}-2\right), 3.50$ (br dd, $\left.J_{2,3}=8.4 \mathrm{~Hz}, 1 \mathrm{H}, \mathrm{H}-3\right), 2.96$ (br m, 2H, H-1a, H-5a), 2.82 
(m, 2H, N-CH $\mathrm{C}_{2} \mathrm{Ar}$ ), 2.66 (m, 2H, N-C $\underline{\mathrm{H}}_{2} \mathrm{CH}_{2} \mathrm{Ar}$ ), 2.40 (br dd, $J_{5 \mathrm{a}, 5 \mathrm{~b}}=12.4 \mathrm{~Hz}, 1 \mathrm{H}, \mathrm{H}-5 \mathrm{~b}$ ), 2.18 (br dd, 1H, H-1b); ${ }^{13} \mathrm{C}$ NMR (150 MHz, $\mathrm{D}_{2} \mathrm{O}$ ) $\delta 140.2$ (C $\mathrm{C}_{\mathrm{q}}$ aromatics), 128.7, 128.6, 126.3 (Caromatics), 73.6 (C3), 67.6 (C2), 67.4 (C4), 58.8 (N- $\left.\mathrm{CH}_{2} \mathrm{CH}_{2} \mathrm{Ar}\right), 56.2$ (C1), 55.5 (C5), 31.8 (N-

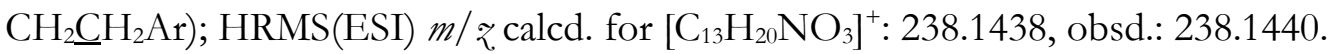<smiles>O[C@H]1CNC[C@@H](O)[C@H]1O</smiles>

(3R,5R)-piperidine-3,4,5-triol (32). Subjecting arabinoside 123 (98.8 mg, $0.36 \mathrm{mmol}$ ) to the general procedure for the synthesis of azasugars from methyl iodo-glycosides using $\mathrm{NH}_{3}(5 \mathrm{ml} / \mathrm{mmol}$, aq. $28 \% \mathrm{w} / \mathrm{w})$ gave azasugar 32 as an amorphous white solid $(14.6 \mathrm{mg}$, $11.0 \mathrm{mmol}, 30 \%) . \mathrm{R}_{f}=0.26\left(\mathrm{DCM} / \mathrm{EtOH} / \mathrm{MeOH} / 28 \%\right.$ aq. $\left.\mathrm{NH}_{3}, 5 / 2 / 2 / 1, \mathrm{v} / \mathrm{v} / \mathrm{v} / \mathrm{v}\right) ;[\alpha]_{D}^{20}=-$ 23.7 (c = 0.13, MeOH); IR (film) 3277, 2929, 1636, 1420, $1069 \mathrm{~cm}^{-1} ;{ }^{1} \mathrm{H}$ NMR $\left(500 \mathrm{MHz}, \mathrm{D}_{2} \mathrm{O}\right) \delta$ $4.33\left(\mathrm{dt}, J_{3,4}=2.9, J_{4,5 \mathrm{a}}=J_{4,5 \mathrm{~b}}=5.9 \mathrm{~Hz}, 1 \mathrm{H}, \mathrm{H}-2\right), 4.17\left(\mathrm{td}, J_{1 \mathrm{a}, 2}=J_{1 \mathrm{~b}, 2}=4.1, J_{2,3}=8.1 \mathrm{~Hz}, 1 \mathrm{H}, \mathrm{H}-4\right)$, $3.86\left(\mathrm{dd}, J_{3,4}=3.0, J_{2,3}=7.8 \mathrm{~Hz}, 1 \mathrm{H}, \mathrm{H}-3\right), 3.51\left(\mathrm{ddd}, J_{1 \mathrm{a}, \mathrm{NH}}=1.2, J_{1 \mathrm{a}, 2}=4.1, J_{1 \mathrm{a}, 1 \mathrm{~b}}=12.7 \mathrm{~Hz}, 1 \mathrm{H}\right.$, $\mathrm{H}-5 \mathrm{a}), 3.39\left(\mathrm{ddd}, J_{5 a, \mathrm{NH}}=1.2, J_{4,5 \mathrm{a}}=6.0, J_{5 \mathrm{a}, 5 \mathrm{~b}}=13.0 \mathrm{~Hz}, 1 \mathrm{H}, \mathrm{H}-1 \mathrm{a}\right), 3.31\left(\mathrm{dd}, J_{4,5 \mathrm{~b}}=2.8, J_{5 a, 5 \mathrm{~b}}=13.0\right.$ $\mathrm{Hz}, 1 \mathrm{H}, \mathrm{H}-1 \mathrm{~b}), 3.05$ (dd, $\left.J_{1 \mathrm{~b}, 2}=8.5, J_{1 \mathrm{a}, 1 \mathrm{~b}}=12.8 \mathrm{~Hz}, 1 \mathrm{H}, \mathrm{H}-5 \mathrm{~b}\right) ;{ }^{13} \mathrm{C} \mathrm{NMR}\left(125 \mathrm{MHz}, \mathrm{D}_{2} \mathrm{O}\right) \delta 70.9$ (C3), 65.1 (C4), 64.9 (C2), 46.3 (C5), 45.7 (C1); HRMS(ESI) m/z calcd. for $\left[\mathrm{C}_{5} \mathrm{H}_{12} \mathrm{NO}_{3}\right]^{+}$: 134.0812, obsd.: 134.0811 .<smiles>O[C@H]1CN(CCc2ccccc2)C[C@@H](O)[C@H]1O</smiles>

(3R,5R)-1-(2-phenylethyl)piperidine-3,4,5-triol (124). Subjecting arabinoside $123(107.4 \mathrm{mg}, 0.39 \mathrm{mmol})$ to the general procedure for the synthesis of azasugars from methyl iodo-glycosides using 2-phenylethylamine (3 equiv.) gave azasugar 124 as an amorphous white solid (46.6 mg, $0.20 \mathrm{mmol}, 50 \%$ ). $\mathrm{R}_{f}=0.55$ (DCM/EtOH/MeOH/28\% aq. $\mathrm{NH}_{3}, 15 / 2 / 2 / 1$, $\mathrm{v} / \mathrm{v} / \mathrm{v} / \mathrm{v}) ;[\alpha]_{D}^{20}=-31.6(\mathrm{c}=0.13, \mathrm{MeOH}) ; \mathrm{IR}\left(\right.$ film) $3374,3241,2822,1453,1348,1081 \mathrm{~cm}^{-1} ;{ }^{1} \mathrm{H}$ NMR (500 MHz, $\left.\mathrm{D}_{2} \mathrm{O}\right)$ 8 7.41-7.27 (m, 5H, Ar), $4.03(\mathrm{~m}, 1 \mathrm{H}, \mathrm{H}-2), 3.89\left(\mathrm{td}, J_{1 \mathrm{a}, 2}=J_{1 \mathrm{~b}, 2}=4.3, J_{2,3}=\right.$ $8.9 \mathrm{~Hz}, 1 \mathrm{H}, \mathrm{H}-4), 3.52$ (br dd, J2,3 = 8.4 Hz, 1H, H-3), 2.98 (br m, 2H, H-1a, H-5a), 2.84 (m, 2H, $\mathrm{N}-\mathrm{CH}_{2} \underline{\mathrm{C}}_{2} \mathrm{Ar}$ ), 2.70 (m, 2H, N-C $\underline{H}_{2} \mathrm{CH}_{2} \mathrm{Ar}$ ), 2.43 (br dd, $J_{5 a, 5 b}=12.4 \mathrm{~Hz}, 1 \mathrm{H}, \mathrm{H}-1 \mathrm{~b}$ ), 2.22 (br dd, $1 \mathrm{H}, \mathrm{H}-5 \mathrm{~b}) ;{ }^{13} \mathrm{C}$ NMR $\left(150 \mathrm{MHz}, \mathrm{D}_{2} \mathrm{O}\right) \delta 140.2$ (C $\mathrm{q}$ aromatics), 128.7, 128.6, 126.2 (C-aromatics), 
73.5 (C3), 67.6 (C2), 67.4 (C4), 58.7 (N- $\left.\mathrm{CH}_{2} \mathrm{CH}_{2} \mathrm{Ar}\right), 56.3$ (C1) 55.5 (C5), 31.8 (N-CH$\left.{ }_{2} \mathrm{CH}_{2} \mathrm{Ar}\right)$; HRMS(ESI) $\mathrm{m} /$ ₹ calcd. for $\left[\mathrm{C}_{13} \mathrm{H}_{20} \mathrm{NO}_{3}\right]^{+}: 238.1438$, obsd.: 238.1445 . 


\section{References}

1. Compain, P.; Martin, O. R., Iminosugars: past, present and future. In Iminosugars: From Synthesis to Therapeutic Applications, Compain, P.; Martin, O. R., Eds. Wiley: Chichester, 2007; pp 1-7.

2. Paulsen, H., Angew. Chem. Int. Ed. Engl. 1962, 1, 597.

3. Paulsen, H., Angew. Chem. Int. Ed. Engl. 1962, 1, 454.

4. Jones, J. K. N.; Szarek, W. A., Can. J. Chem. 1963, 41, 636-640.

5. Jones, J. K. N.; Turner, J. C., J. Chem. Soc. 1962, 4699-4703.

6. Haskell, T. H.; Hanessian, S., J. Org. Chem. 1963, 28 (10), 2604-2610.

7. Hanessian, S., Chem. Commun. 1966, 796-798.

8. Paulsen, H., Angew. Chem. Int. Ed. Engl. 1966, 5, 495-510.

9. Inouye, S.; Tsuruoka, T.; Ito, T.; Niida, T., Tetrahedron 1968, 23, 2125-2144.

10. Block, T. M.; Lu, X.; Platt, F. M.; Foster, G. R.; Gerlich, W. H.; Blumberg, B. S.; Dwek, R. A., Proc. Natl. Acad. Sci. USA 1994, 91, 2235-2239.

11. Karpas, A.; Fleet, G. W.; Dwek, R. A.; Petursson, S. N., S. K.; Ramsden, N. G.; Jacob, G. S.; Rademacher, T. W., Proc. Natl. Acad. Sci. USA 1988, 85, 9229-9233.

12. Chen, H.; Hao, L.; Zhu, M.; Yang, T.; Wei, S.; Qin, Z.; Zhang, P.; Li, X., Bioorg. Med. Chem. Lett 2014, 24, 3426-3429.

13. Bernacki, R. J.; Niedbala, M. J.; Korytnyk, W., Cancer and Metast. Rev. 1985, 4, 81-102.

14. Lairson, L. L.; Henrissat, B.; Davies, G. J.; Withers, S. G., Annu. Rev. Biochem. 2008, 77, 521-555.

15. Zechel, D. L.; Withers, S. G., Acc. Chem. Res. 2000, 33, 11-18.

16. Wang, Q.; Graham, R. W.; Trimbur, D.; Warren, R. A. J.; Withers, S. G., J. Am. Chem. Soc. 1994, 116, 11594-11595.

17. Szczepina, M. G.; Johnston, B. D.; Yuan, Y.; Svensson, B.; Mario Pinto, B., J. Am. Chem. Soc. 2004, 126 (39), 12458-12469.

18. de Melo, E. B.; Da Silveira Gomes, A.; Carvalho, I., Tetrahedron 2006, 62, 10277-10302.

19. Fuller, M.; Meikle, P. J.; Hopwood, J. J., Epidemiology of lysosomal storage diseases. In Fabry Disease: Perspectives from 5 Years of FOS, Mehta, A.; Beck, M.; Sunder-Plassmann, G., Eds. Oxford PharmaGenesis: Oxford, 2006.

20. Beck, M., Dev. Med. Child Neurol. 2018, 60 (1), 13-18.

21. Sánchez-Fernández, E. M.; García Fernández, J. M.; Mellet, C. O., Chem. Commun. 2016, 52, 5497-5515.

22. Valenzano, K. J.; Khanna, R.; Power, A. C., Jr.; Boyd, R.; Lee, G.; Flanagan, J. J.; Benjamin, E. R., Assay Drug Dev. Technol. 2011, 9 (3), 213-235.

23. Hill, C. H.; Viuff, A. G.; Spratley, S. J.; Salamone, S.; Christensen, S. H.; Read, R. J.; Moriarty, N. W.; Jensen, H. H.; Deane, J. E., Chem. Sci. 2015, 6, 3075-3086.

24. Starzl, T. E.; Murase, N.; Abu-Elmagd, K.; Gray, E. A.; Shapiro, R.; Eghtesad, B.; Corry, R. J.; Jordan, M. L.; Fontes, P.; Gayowski, T.; Bond, G.; Scantlebury, V. P.; Potdar, S.; Randhawa, P.; Zeevi, T. W. A.; Nalesnik, M. A.; Woodward, J.; Marcos, A.; Trucco, M.; Demetris, A. J.; Fung, J. J., 361 2003, 1502-1510.

25. Heneghan, M. A.; McFarlane, I. G., Hepatology 2002, 35 (1), 7-13.

26. Ward, L.; Paquette, J.; Seidman, E.; Huot, C.; Alvarez, F.; Crock, P.; Delvin, E.; Kampe, O.; Deal, C., J. Clin. Endocrinol. Metab. 1999, 84 (3), 844-852.

27. Myers, B. D.; Sibley, R.; Newton, L.; Tomlanovich, S. J.; Boshkos, C.; Stinson, E.; Luetscher, J. A.; Whitney, D. J.; Krasny, D.; Coplon, N. S.; PerIroth, M. G., Kidney Int. 1988, 33 (2), 590-600.

28. Merkel, S.; Mogilevskaja, N.; Mengel, M.; Haller, H.; Schwarzz, A., Transplant Proc. 2006, 38, 714-715.

29. Wang, G.-N.; Xiong, Y.; Ye, J.; Zhang, L.-H.; Ye, X.-S., ACS Med. Chem. Lett. 2011, 2, 682-686.

30. Zhou, J.; Zhang, Y.; Zhou, X.; Zhou, J.; Zhang, L.-H.; Ye, X.-S.; Zhang, X.-L., Bioorg. Med. Chem. 2008, 16, 1605-1612.

31. Yang, X.; Xiong, D.-C.; Song, C.; Tai, G.; Ye, X.-S., Org. Biomol. Chem. 2015, 13, 9364-9368. 
32. Liu, H.-Q.; Song, C.-C.; Niu, Y.-H.; Liu, T.; Li, Q.; Ye, X.-S., Org. Biomol. Chem. 2017, 15, 59125919.

33. Lahiri, R.; Ansari, A. A.; Vankar, Y. D., Chem. Soc. Rev. 2013, 42, 5102-5118.

34. Boldi, A. M., Carbohydrate-Derived Small-Molecule Libraries. In Combinatorial Synthesis of Natural Product-Based Libraries (Critical Reviews in Combinatorial Chemistry), Boldi, A. M., Ed. CRC press: 2006; pp 165-184.

35. Cox, T.; Lachmann, R.; Hollak, C.; Aerts, J.; van Weely, S.; Hrebícek, M.; Platt, F. M.; Butters, T.; Dwek, R.; Moyses, C.; Gow, I.; Elstein, D.; Zimran, A., Lancet 2000, 355, 1481-1485.

36. Platt, F. M.; Neises, G. R.; Karlsson, G. B.; Dwek, R. A.; Butters, T. D., J. Biol. Chem. 1994, 269 (43), 27108-27114.

37. Platt, F. M.; Neises, G. R.; Dwek, R. A.; Butters, T., J. Biol. Chem. 1994, 269 (11), 8362-8365.

38. Zavesca $100 \mathrm{mg}$ hard capsules: summary of product characteristics.

39. Yee, H. S.; Fong, N. T., Pharmacotherapy 1996, 16 (5), 792-805.

40. Vichayanrat, A.; Ploybutr, S.; Tunlakit, M.; Watanakejorn, P., Diabetes Res. Clin. Pract. 2002, 55, 99-103.

41. Sugimoto, S.; Nakajima, H.; Kosaka, K.; Hosoi, H., Nutr. Metab. 2015, 12, 51-57.

42. Therapeutics, A. Amicus Therapeutics Announces European Commission Approval for Galafold $^{\mathrm{TM}}$ (Migalastat) in Patients with Fabry Disease in European Union. (accessed May 31).

43. Therapeutics, A. Amicus Therapeutics Announces Approval for Galafold ${ }^{\text {TM }}$ (Migalastat) for Treatment of Fabry Disease in Australia. (accessed August 15).

44. Therapeutics, A. Amicus Therapeutics Announces Approval for Galafold ${ }^{\mathrm{TM}}$ (Migalastat) for Treatment of Fabry Disease in Canada. (accessed August 15).

45. Asano, N.; Ishii, S.; Kizu, H.; Ikeda, K.; Yasuda, K.; Kato, A.; Martin, O. R.; Fan, J.-Q., Eur. J. Biochem. 2000, 267, 4179-4186.

46. Fan, J.-Q.; Ishii, S.; Asano, N.; Suzuki, Y., Nat. Med. 1999, 5 (1), 112-115.

47. Paulsen, H., Justus Liebigs Ann. Chem. 1965, 683, 187-198.

48. Bernotas, R. C.; Papandreou, G.; Urbach, J.; Ganem, B., Tetrahedron Lett. 1990, 31 (24), 33933396.

49. Sekioka, T.; Shibano, M.; Kusano, G., Nat. Med. 1995, 49, 332-335.

50. Tori, M.; Ohara, Y.; Nakashima, K.; Sono, M., J. Nat. Prod. 2001, 64, 1048-1051.

51. Igarashi, Y.; Ichikawa, M.; Ichikawa, Y., Bioorg. Med. Chem. Lett 1996, 6 (5), 553-558.

52. Godskesen, M.; Lundt, I.; Madnes, R.; Winchester, B., Bioorg. Med. Chem. 1996, 4 (11), 18571865.

53. Häusler, H.; Rupitz, K.; Stütz, A. E.; Withers, S. G., Monatsh. Chem. 2002, 133, 555-560.

54. Lovering, A. L.; Lee, S. S.; Kim, Y.-W.; Withers, S. G.; Strynadka, N. C. J., J. Biol. Chem. 2005, 280 (3), 2105-2115.

55. Compain, P.; Martin, O. R.; Boucheron, C.; Godin, G.; Yu, L.; Ikeda, K.; Asano, N., ChemBioChem 2006, 7, 1356-1359.

56. Han, H., Tetrahedron Lett. 2003, 44, 1567-1569.

57. Front, S.; Gallienne, E.; Charollais-Thoenig, J.; Demotz, S.; Martin, O. R., ChemMedChem 2016, 11, 133-141.

58. Deeble, B. The efficient synthesis of 1-deoxymannojirrimycin and its derivatives. Victoria University of Wellington, Wellington, 2016.

59. Hunt-Painter, A. Methodology Development for the Synthesis of Iminosugars. Victoria University of Wellington, Wellington, 2018.

60. Garegg, P. J.; Regberg, T.; Stawiński, J.; Strömberg, R., J. Chem. Soc. Perkin Trans. 2 1987, 271 274.

61. Lyseng-Williamson, K. A., Drugs 2014, 74 (1), 61-74.

62. Li, N.-S.; Lu, J.; Piccirilli, J. A., Org. Lett. 2007, 9 (16), 3009-3012.

63. El Khadem, H. S.; Audichya, T. D.; Niemeyer, D. A.; Kloss, J., Carbohydr. Res. 1976, 47, 233-240.

64. Skaanderup, P. R.; Poulsen, C. S.; Hyldtoft, L.; Jørgensen, M. R.; Madsen, R., Synthesis 2002, 1721-1727. 
65. Tachrim, Z. P.; Wang, L.; Yoshida, T.; Muto, M.; Nakamura, T.; Masuda, K.; Hashidoko, Y.; Hashimoto, M., ChemistrySelect 2016, 1, 58-62.

66. Fleet, G. W.; Smith, P. W., Tetrahedron 1986, 42 (20), 5685-5692.

67. van Kalkeren, H.; van Delft, F.; Rutjes, F. P. J. T., Pure Appl. Chem. 2012, 85 (4), 817-828.

68. Dangerfield, E. M.; Timmer, M. S. M.; Stocker, B. L., Org. Lett. 2009, 11 (3), 535-538.

69. Shankar, B. B.; Kirkup, M. P.; McCombie, S. W.; Ganguiy, A. K., Tetrahedron Lett. 1993, 34 (45), 7171-7174.

70. Pastores, G. M.; Barnett, N. L.; Kolodny, E. H., Clin. Ther. 2005, 27, 1215-1227.

71. McCaig, A. E.; Chomier, B.; Wightmaan, R. H., J. Carbohydr. Chem. 1994, 13 (3), 397-407.

72. Scott, L. J.; Spencer, C. M., Drugs 2000, 59 (3), 521-549.

73. Heath, P.; Mann, J.; Walsh, E. B., J. Chem. Soc. Perkin Trans. 1 1983, 0, 2675-2679.

74. Ichikawa, Y.; Igarashi, Y.; Ichikawa, M.; Suhara, Y., J. Am. Chem. Soc. 1998, 120, 3007-3018.

75. Mizutani, K.; Kasai, R.; Nakamura, M.; Tanaka, O., Carbohydr. Res. 1989, 185 (27-38).

76. Chang, Y.-F.; Guo, C.-W.; Chan, T.-H.; Pan, Y.-W.; Tsuo, E.-L.; Cheng, W.-C., Mol. Divers. 2011, 15, 203-214. 


\section{Appendix}

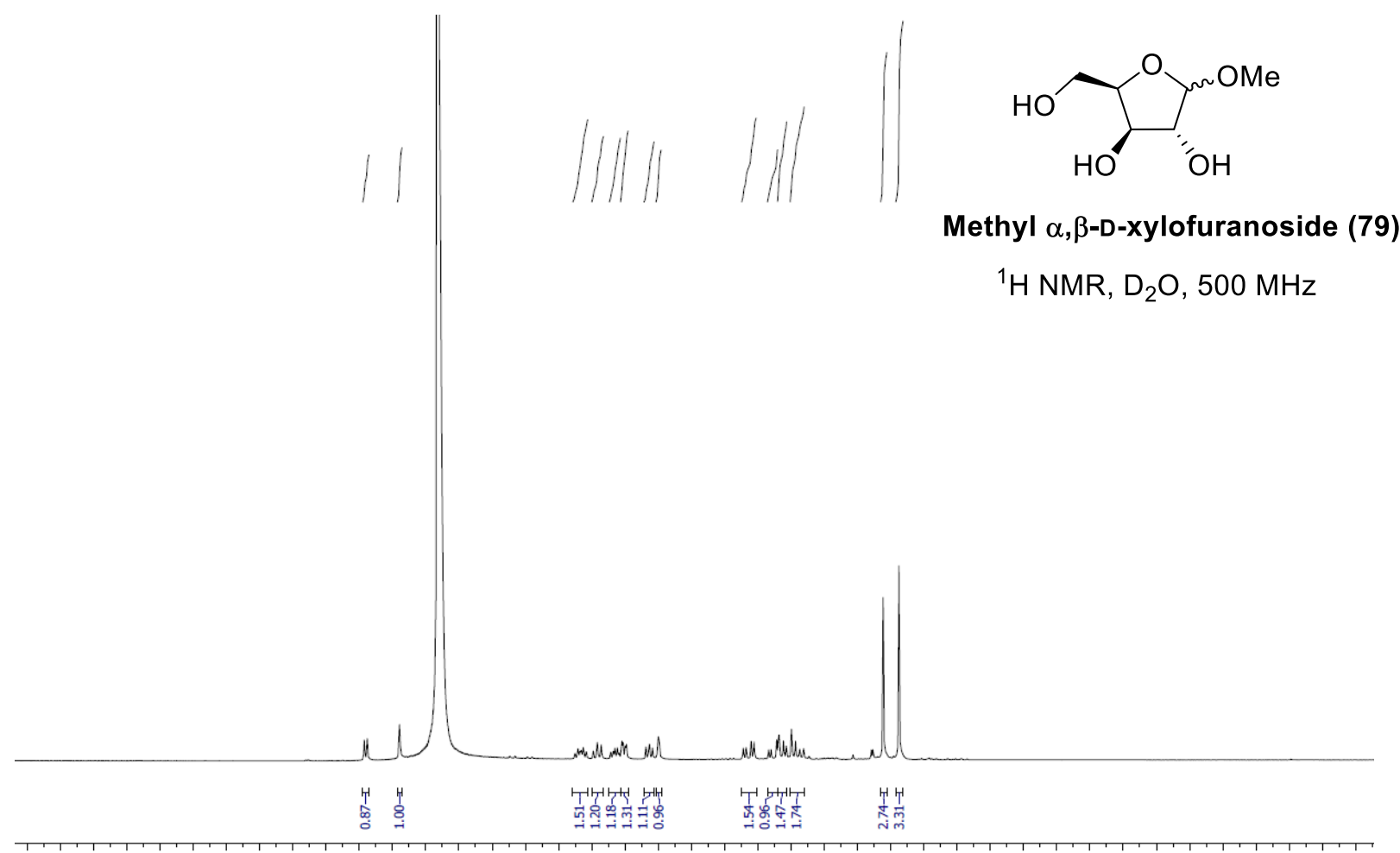

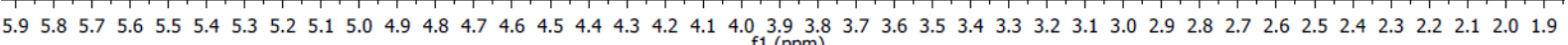

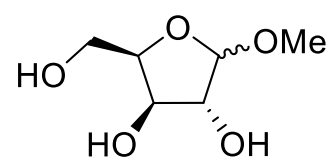

Methyl $\alpha, \beta$-D-xylofuranoside (79)

${ }^{13} \mathrm{C}$ NMR, $\mathrm{D}_{2} \mathrm{O}, 125 \mathrm{MHz}$

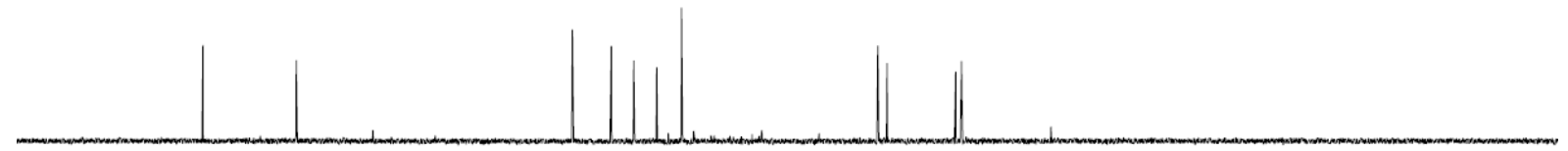

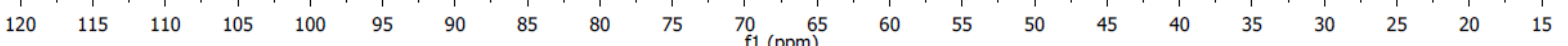



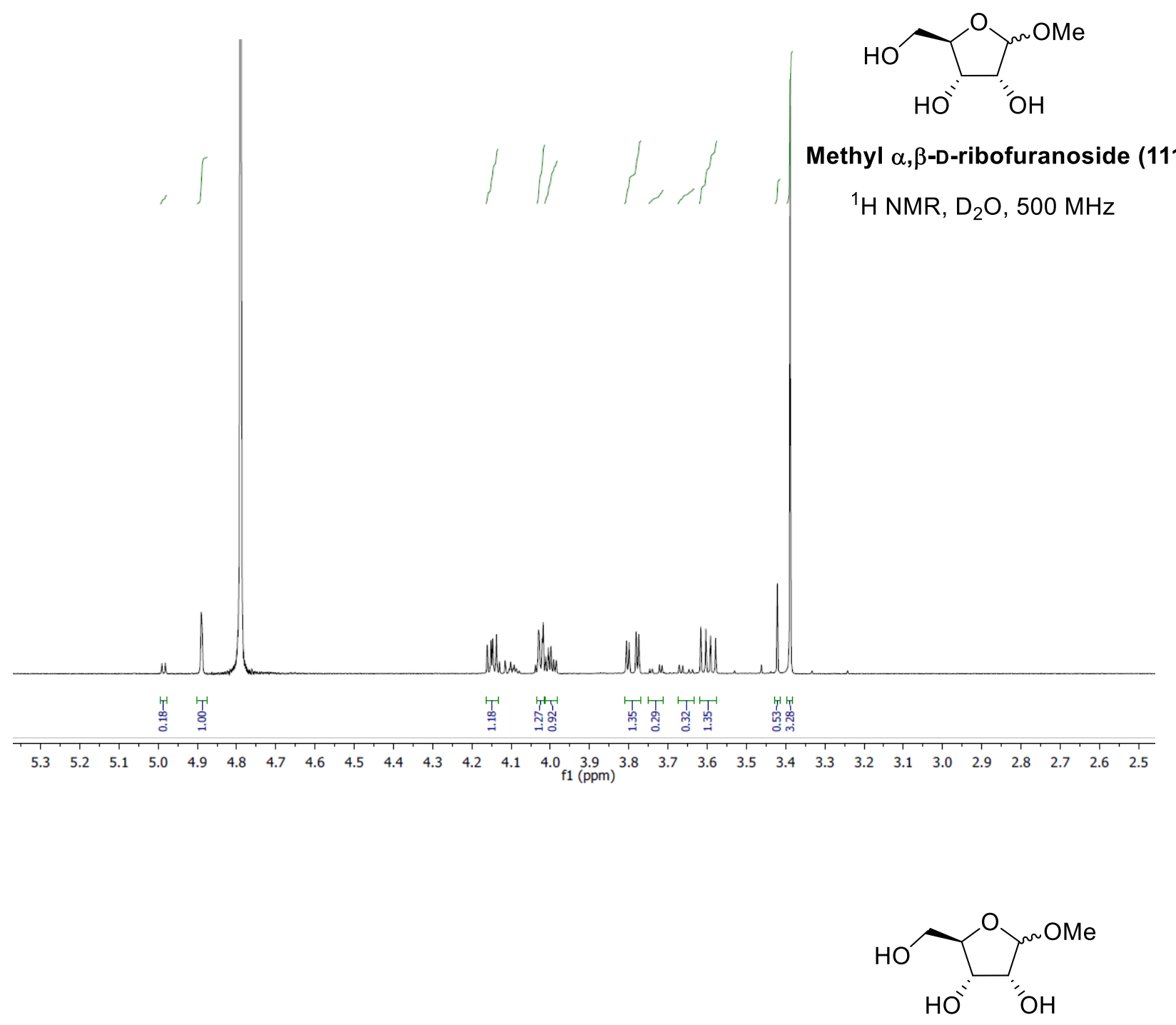

Methyl $\alpha, \beta$-D-ribofuranoside (111)

${ }^{13} \mathrm{C} N M R, \mathrm{D}_{2} \mathrm{O}, 125 \mathrm{MHz}$ 

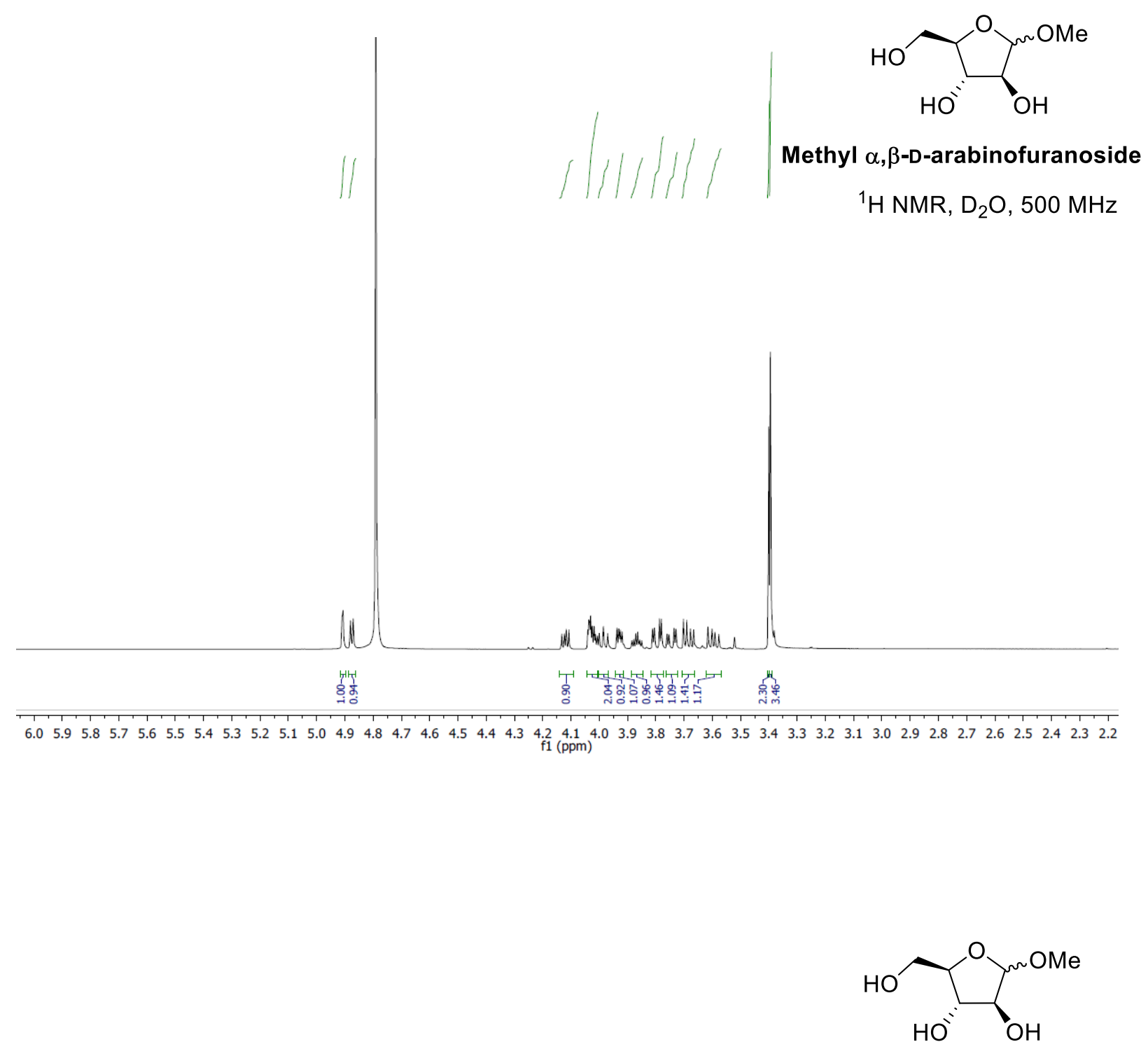

Methyl $\alpha, \beta$-D-arabinofuranoside (122)

${ }^{13} \mathrm{C} N M R, \mathrm{D}_{2} \mathrm{O}, 125 \mathrm{MHz}$ 

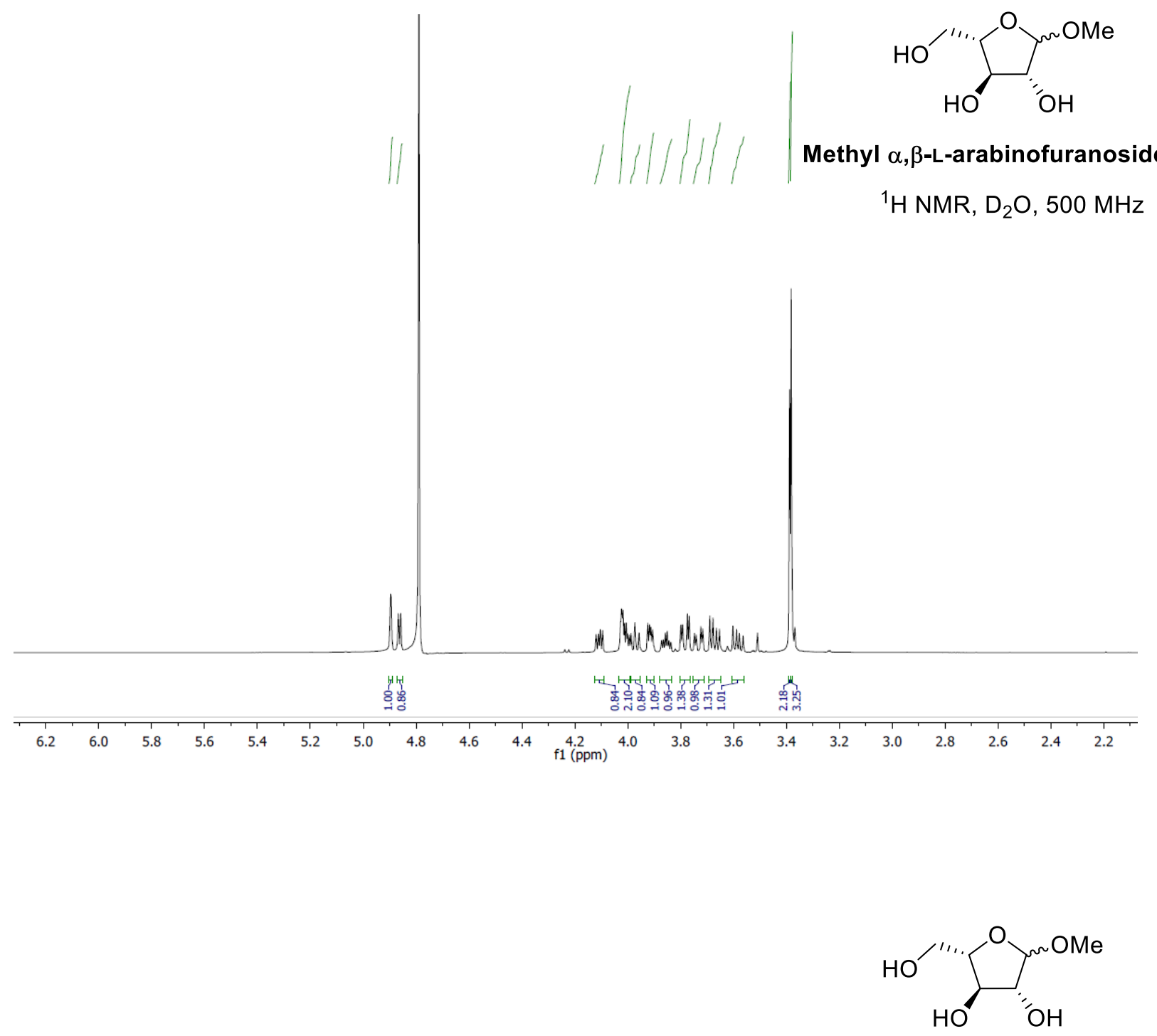

Methyl $\alpha, \beta$-L-arabinofuranoside (119)

${ }^{13} \mathrm{C}$ NMR, $\mathrm{D}_{2} \mathrm{O}, 125 \mathrm{MHz}$

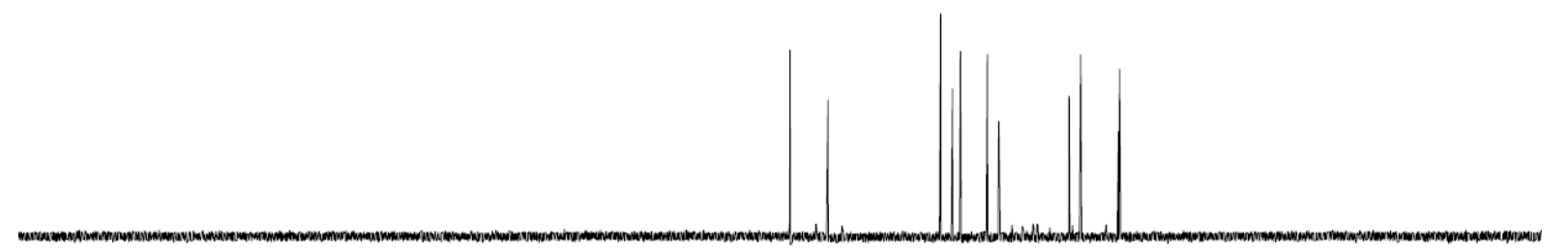

$\begin{array}{rlllllllllllllllllllllllllllll}230 & 220 & 210 & 200 & 190 & 180 & 170 & 160 & 150 & 140 & 130 & 120 & 110 & 100 & 90 & 80 & 70 & 60 & 50 & 40 & 30 & 20 & 10 & 0 & -10\end{array}$ 


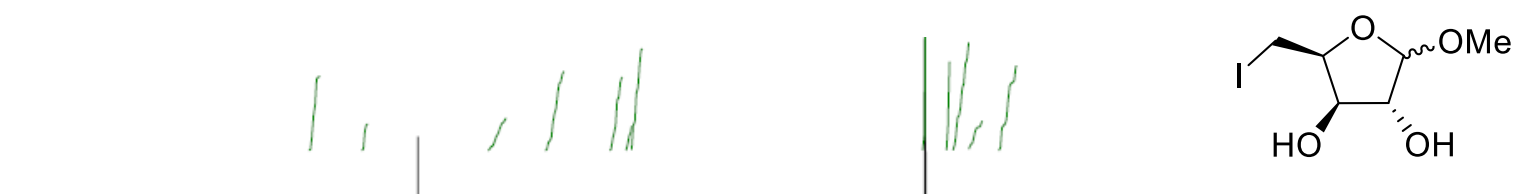

Methyl 5-iodo- $\alpha, \beta$-D-xylofuranoside (80)

${ }^{1} \mathrm{H}$ NMR, $\mathrm{D}_{2} \mathrm{O}, 500 \mathrm{MHz}$
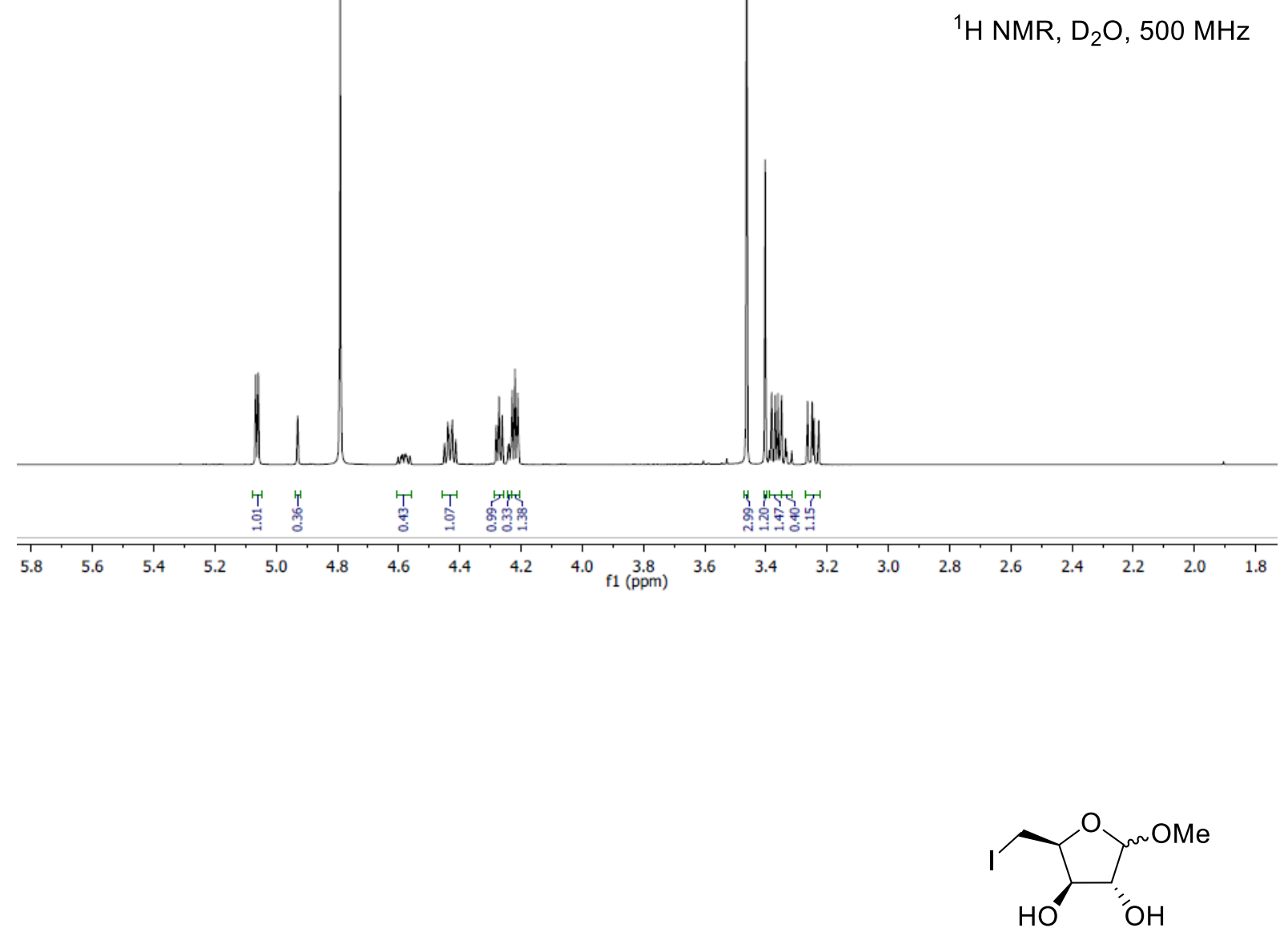

Methyl 5-iodo- $\alpha, \beta$-D-xylofuranoside (80)

${ }^{13} \mathrm{C}$ NMR, $\mathrm{D}_{2} \mathrm{O}, 125 \mathrm{MHz}$

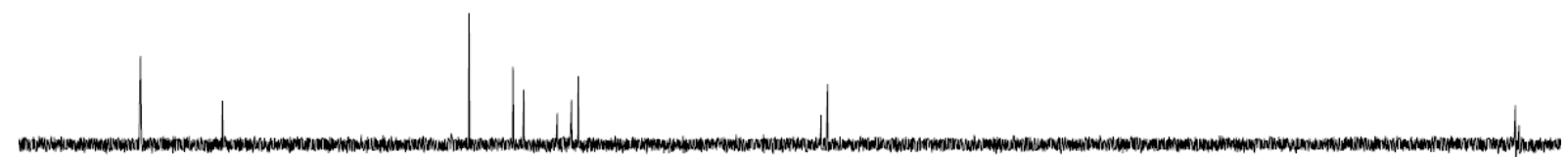




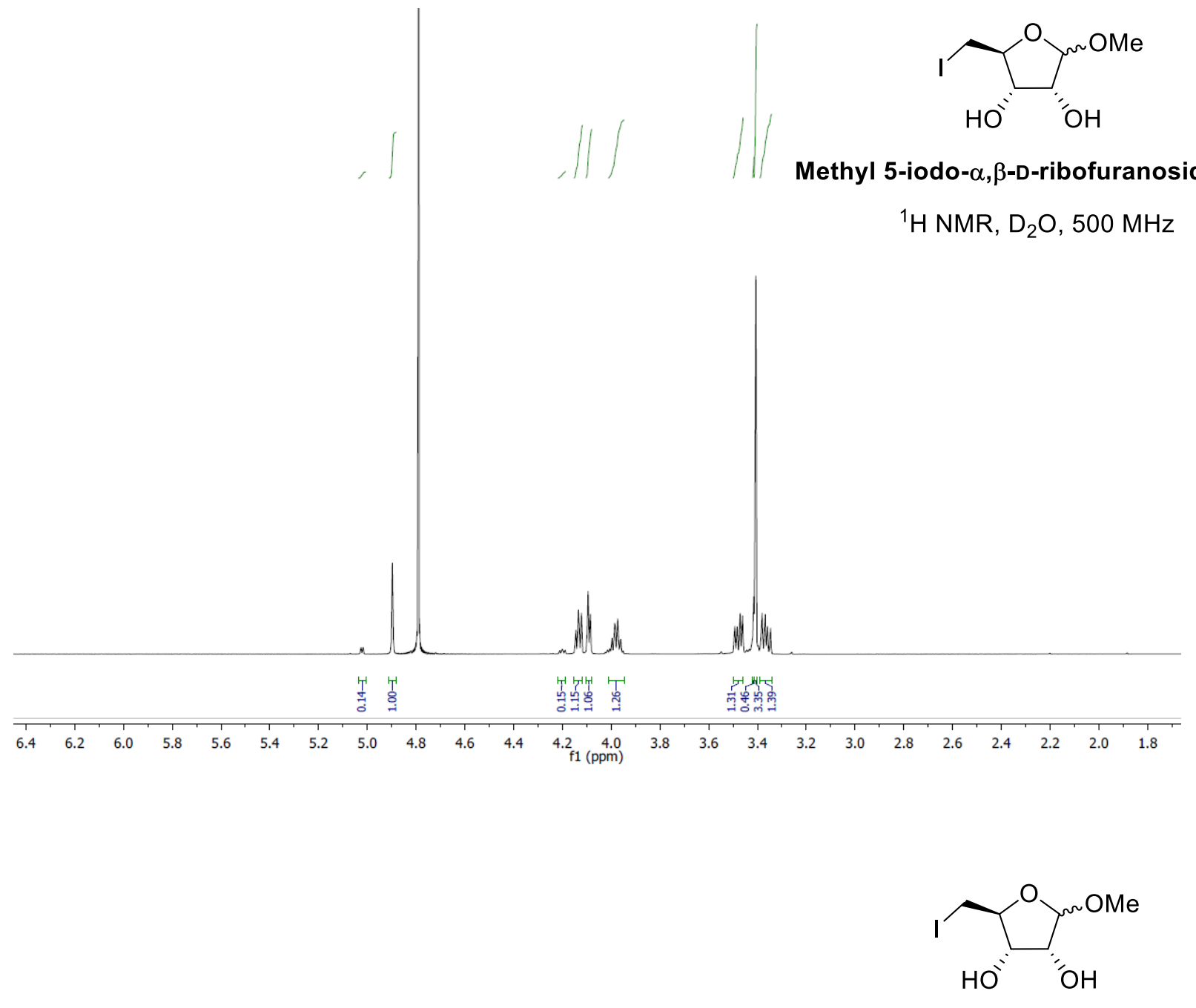

Methyl 5-iodo- $\alpha, \beta$-D-ribofuranoside (112)

${ }^{13} \mathrm{C} N M R, \mathrm{D}_{2} \mathrm{O}, 125 \mathrm{MHz}$

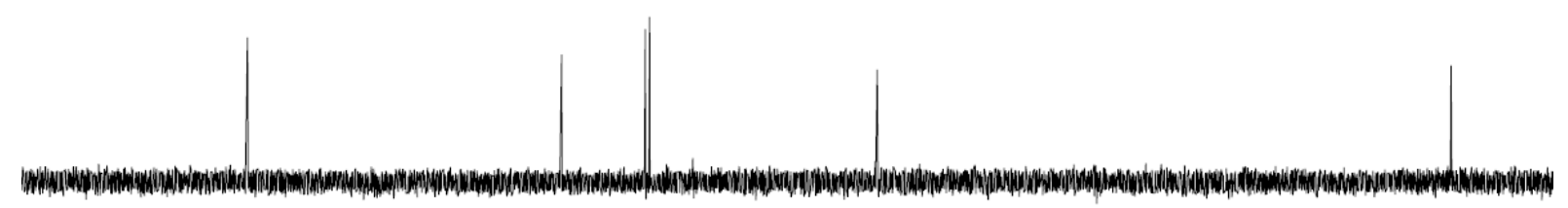

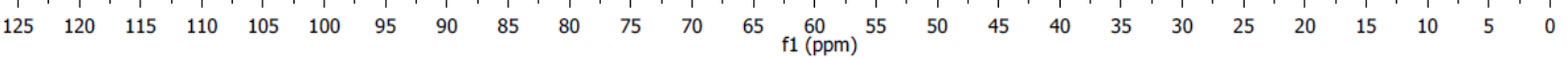




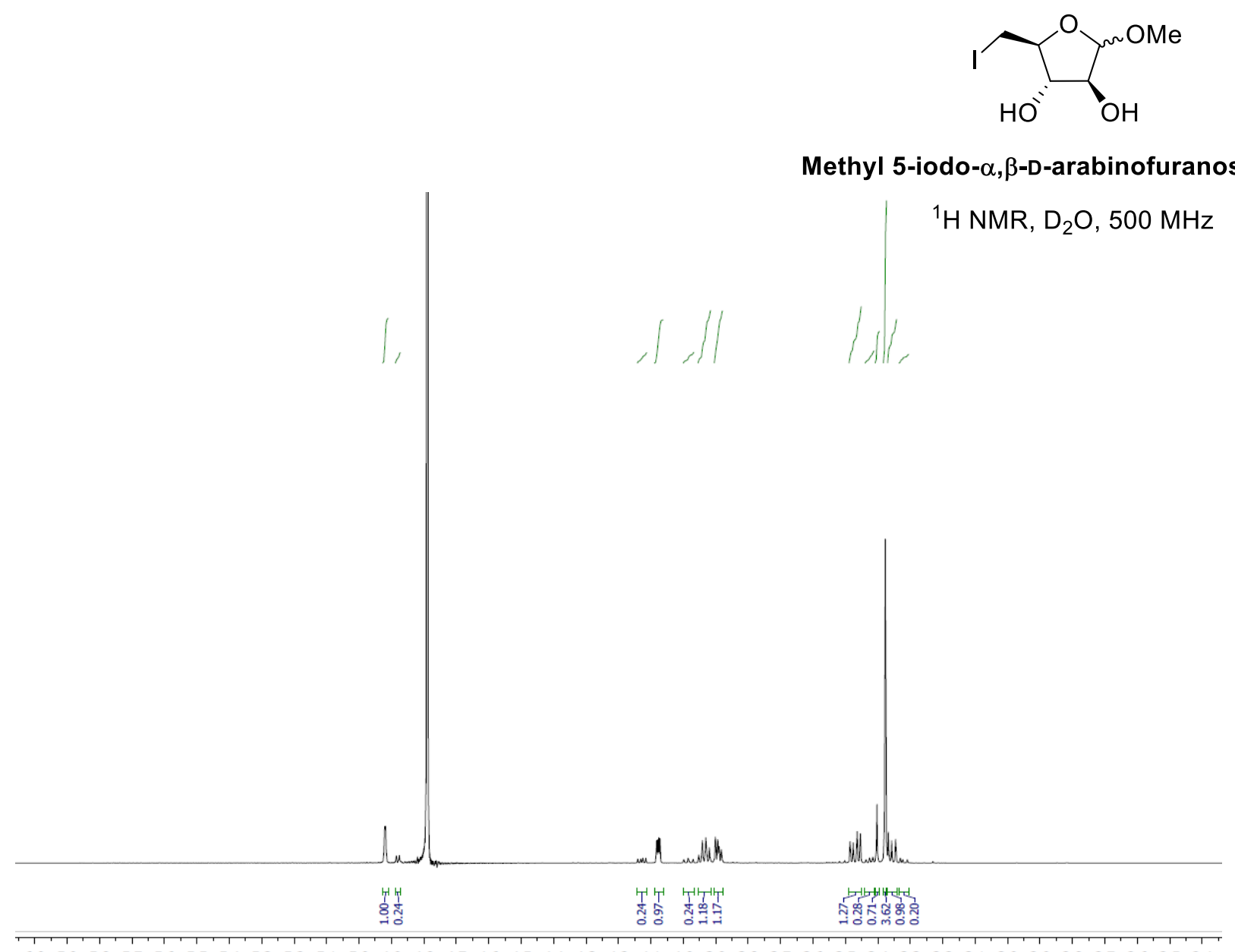

$\begin{array}{lllllllllllllllllllllllllllllllllllllllll}6.0 & 5.9 & 5.8 & 5.7 & 5.6 & 5.5 & 5.4 & 5.3 & 5.2 & 5.1 & 5.0 & 4.9 & 4.8 & 4.7 & 4.6 & 4.5 & 4.4 & 4.3 & 4.2 & 4.1 & 4.0 & 3.9 & 3.8 & 3.7 & 3.6 & 3.5 & 3.4 & 3.3 & 3.2 & 3.1 & 3.0 & 2.9 & 2.8 & 2.7 & 2.6 & 2.5 & 2.4\end{array}$<smiles>CO[C@H]1O[C@H](CI)[C@@H](O)[C@H]1O</smiles>

Methyl 5-iodo- $\alpha, \beta$-D-arabinofuranoside (123)

${ }^{13} \mathrm{C}$ NMR, $\mathrm{D}_{2} \mathrm{O}, 125 \mathrm{MHz}$

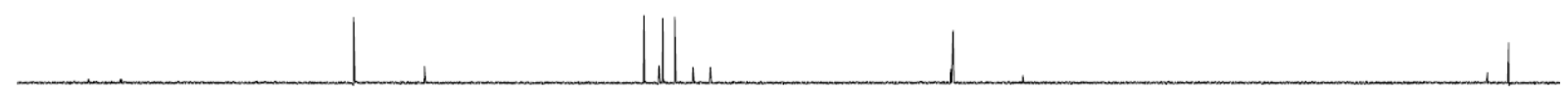

$\begin{array}{lllllllllllllllllllllllllll}135 & 130 & 125 & 120 & 115 & 110 & 105 & 100 & 95 & 90 & 85 & 80 & 75 & \underset{\mathrm{f} 1}{70}(\mathrm{ppm}) \\ 65 & 60 & 55 & 50 & 45 & 40 & 35 & 30 & 25 & 20 & 15 & 10 & 5 & \end{array}$ 

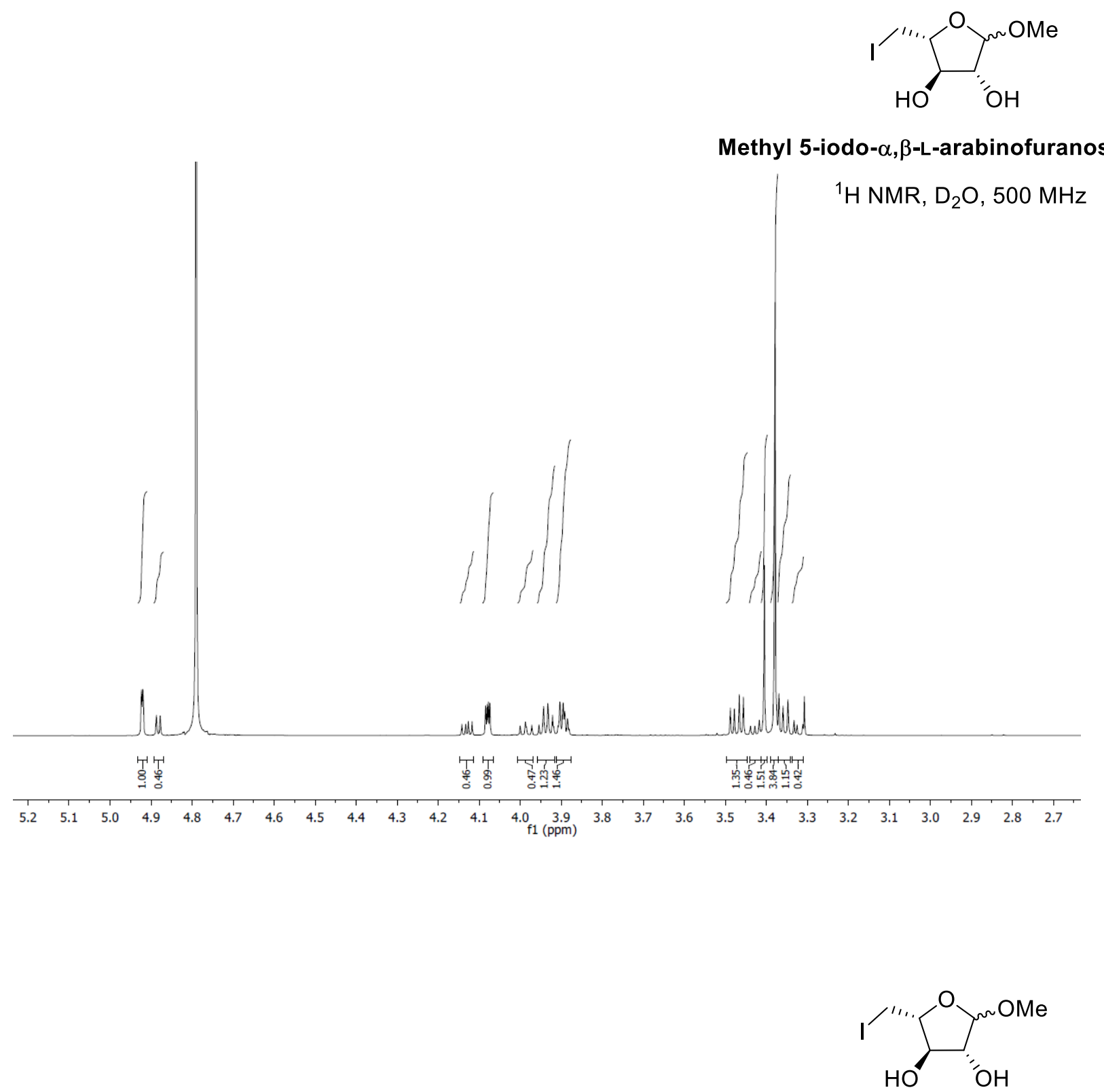

Methyl 5-iodo- $\alpha, \beta$-L-arabinofuranoside (120)

${ }^{13} \mathrm{C}$ NMR, $\mathrm{D}_{2} \mathrm{O}, 125 \mathrm{MHz}$

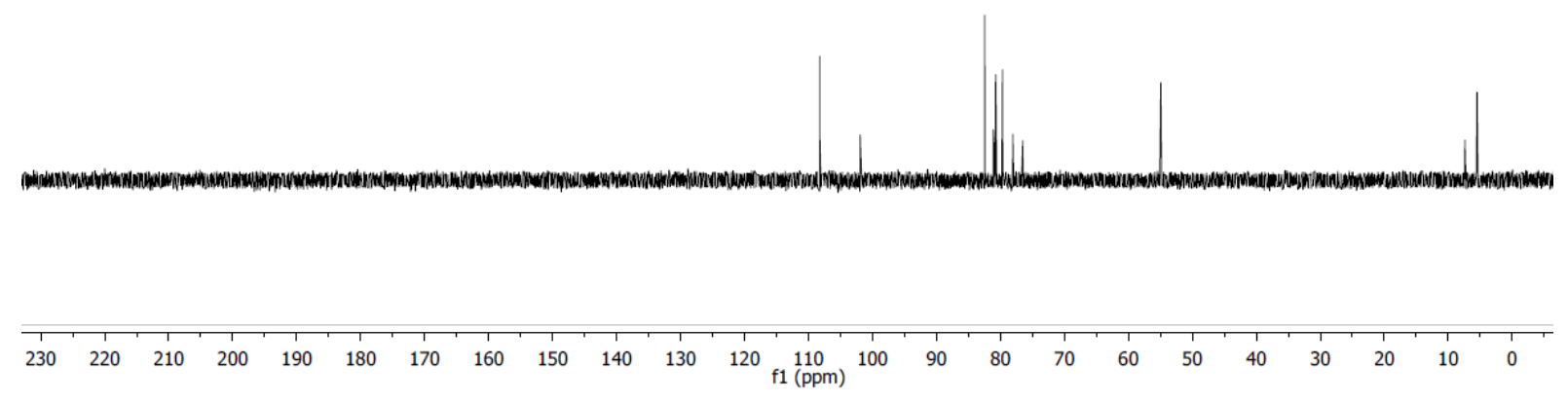




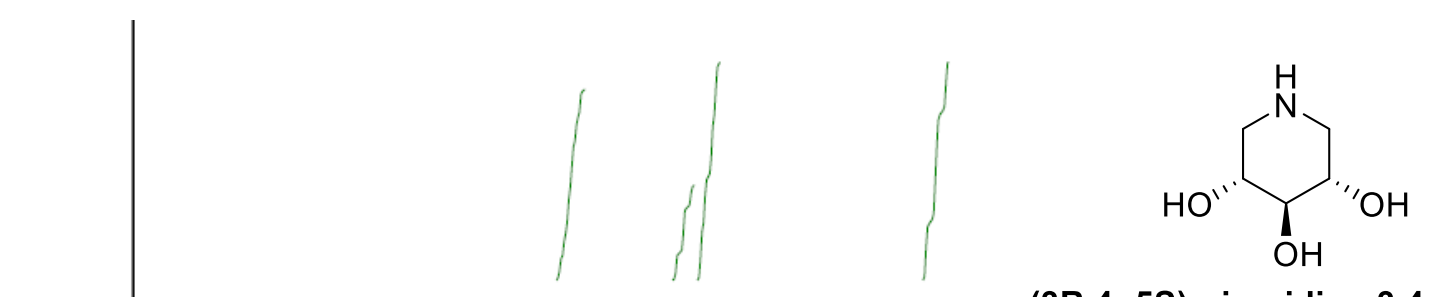

(3R,4r,5S)-piperidine-3,4,5-triol (30)

${ }^{1} \mathrm{H}$ NMR, $\mathrm{D}_{2} \mathrm{O}, 500 \mathrm{MHz}$

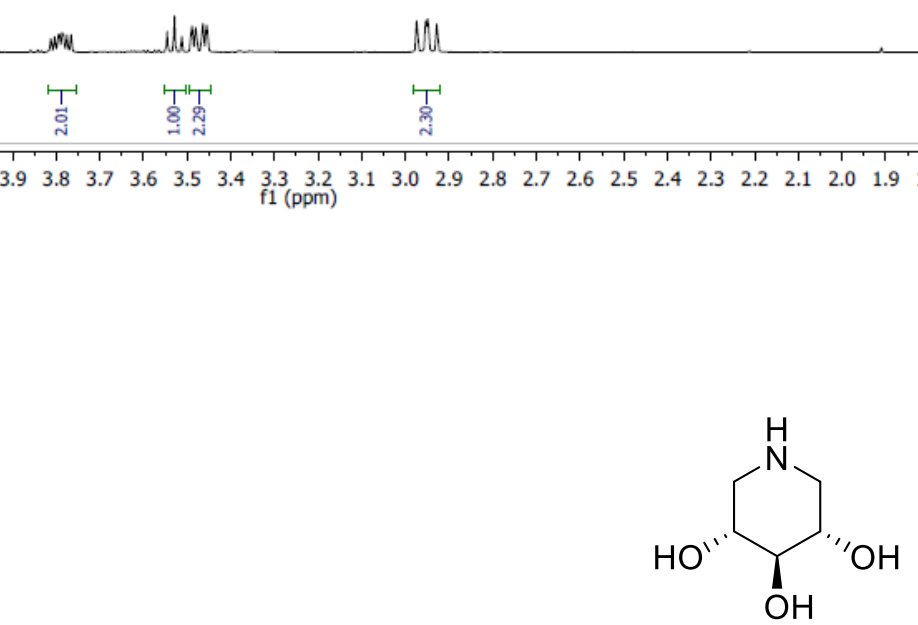

(3R,4r,5S)-piperidine-3,4,5-triol (30)

${ }^{13} \mathrm{C}$ NMR, $\mathrm{D}_{2} \mathrm{O}, 125 \mathrm{MHz}$

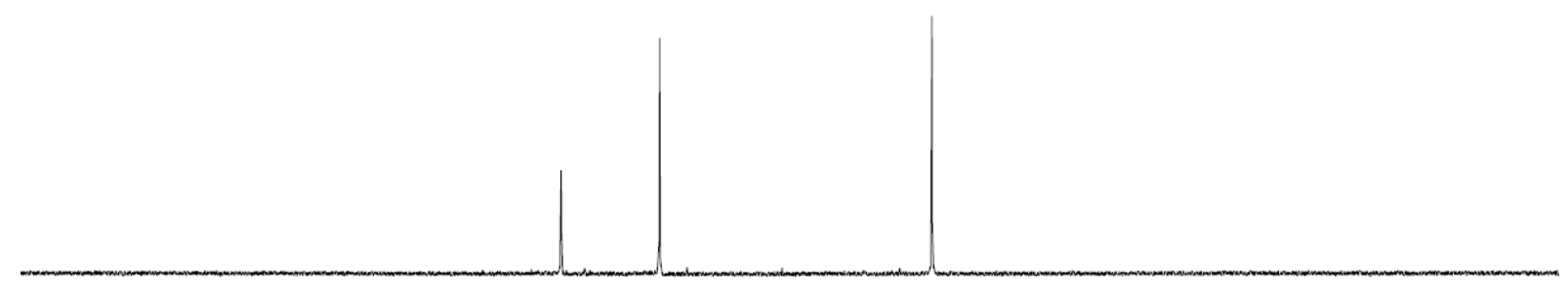

$\begin{array}{llllllllllllllllllllllllll}115 & 110 & 105 & 100 & 95 & 90 & 85 & 80 & 75 & 70 & 65 & \underset{\mathrm{f} 1(\mathrm{ppm})}{60} & 55 & 50 & 45 & 40 & 35 & 30 & 25 & 20 & 15 & 10 & 5 & 0\end{array}$ 


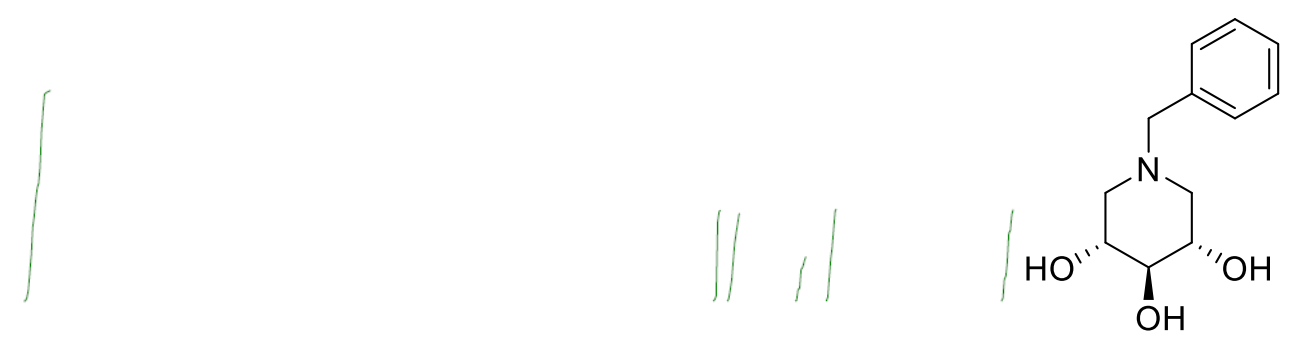

(3R,4r,5S)-1-benzylpiperidine-3,4,5-triol (101)

${ }^{1} \mathrm{H}$ NMR, $\mathrm{D}_{2} \mathrm{O}, 500 \mathrm{MHz}$
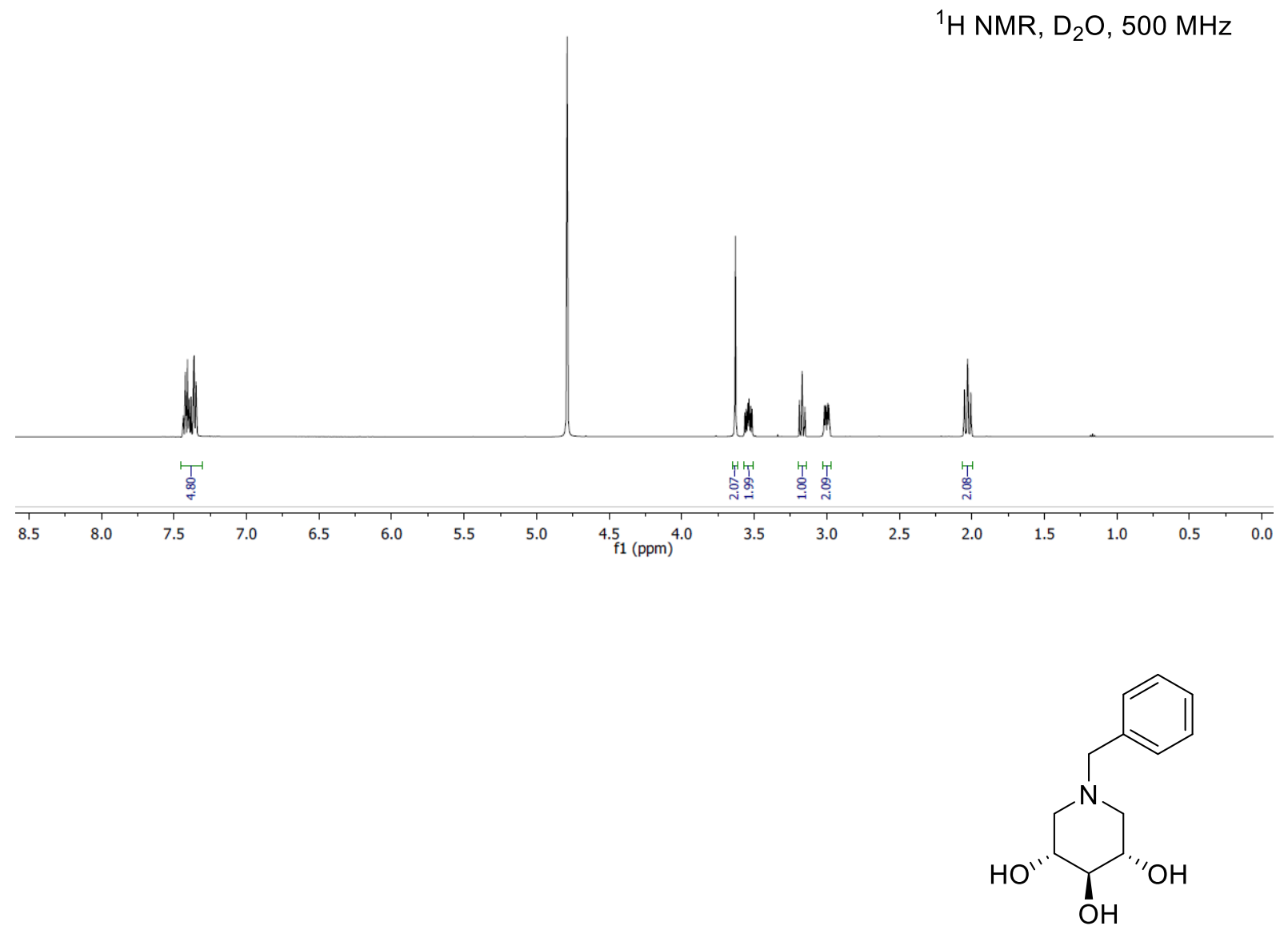

(3R,4r,5S)-1-benzylpiperidine-3,4,5-triol (101)

${ }^{13} \mathrm{C} \mathrm{NMR}, \mathrm{D}_{2} \mathrm{O}, 125 \mathrm{MHz}$
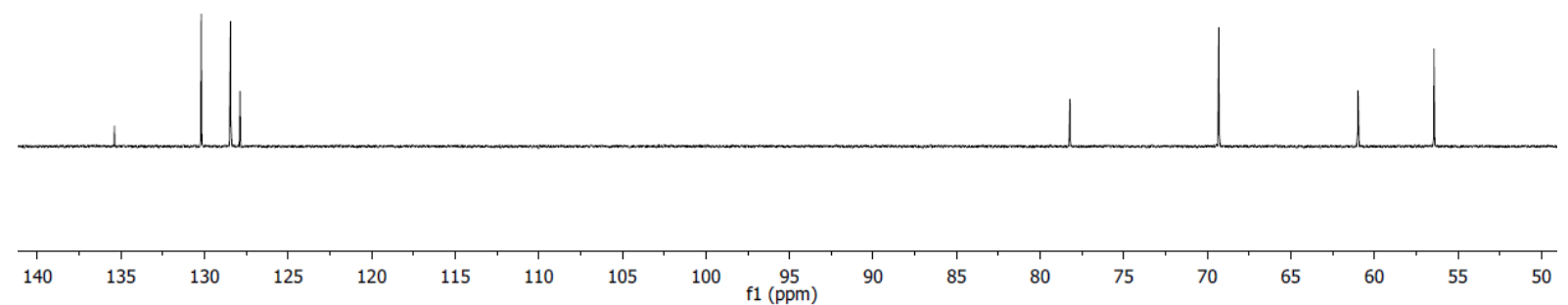

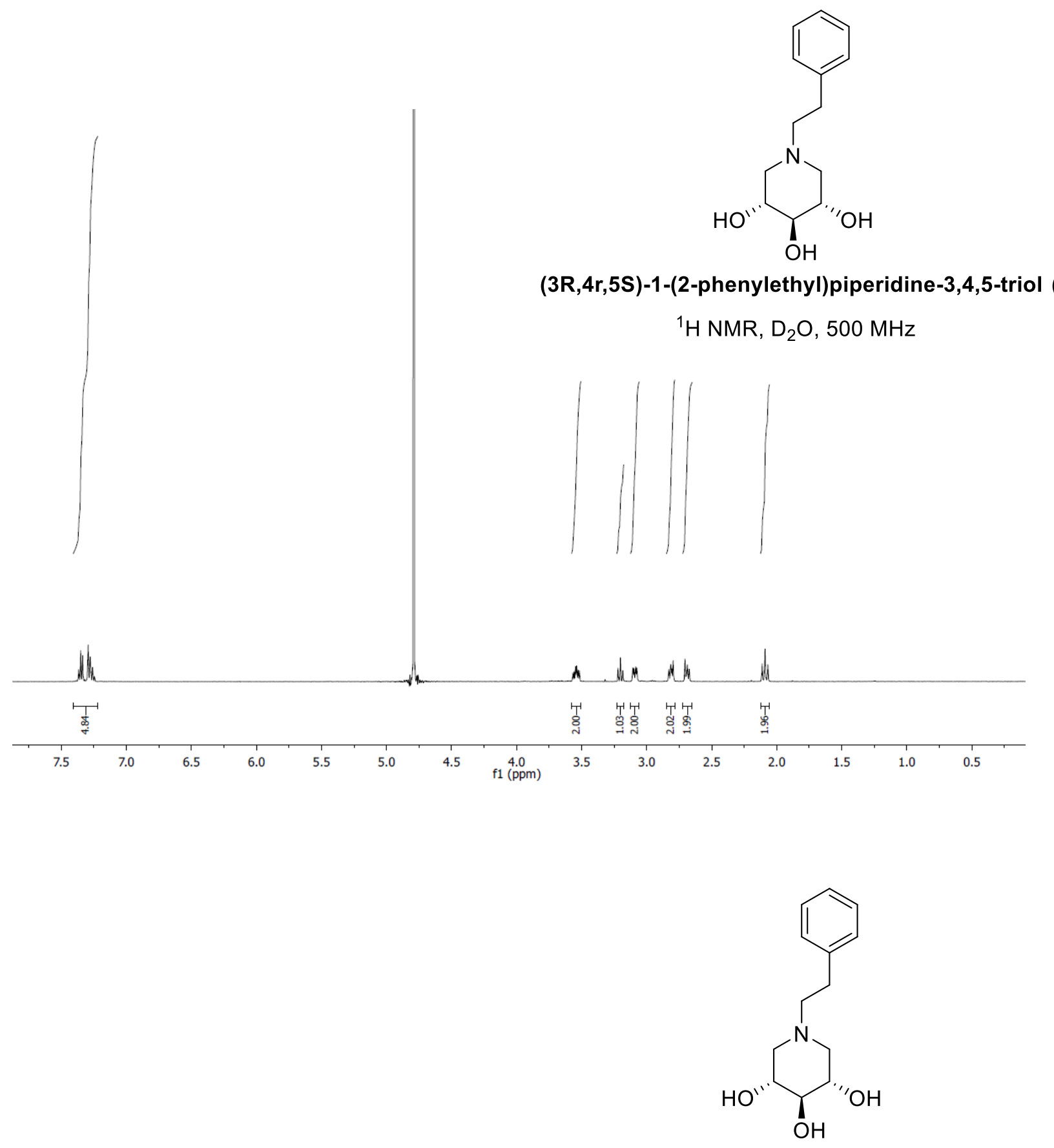

(3R,4r,5S)-1-(2-phenylethyl)piperidine-3,4,5-triol (102)

${ }^{13} \mathrm{C}$ NMR, $\mathrm{D}_{2} \mathrm{O}, 125 \mathrm{MHz}$

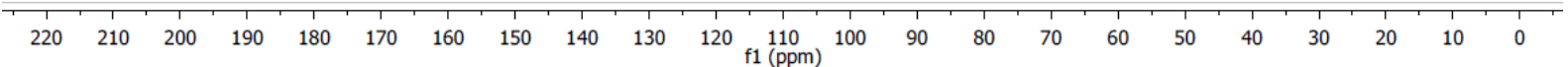


<smiles>CCCCN1C[C@H](O)[C@H](O)[C@H](O)C1</smiles>

(3R,4r,5S)-1-butylpiperidine-3,4,5-triol (103)

${ }^{1} \mathrm{H} N M R, \mathrm{D}_{2} \mathrm{O}, 500 \mathrm{MHz}$

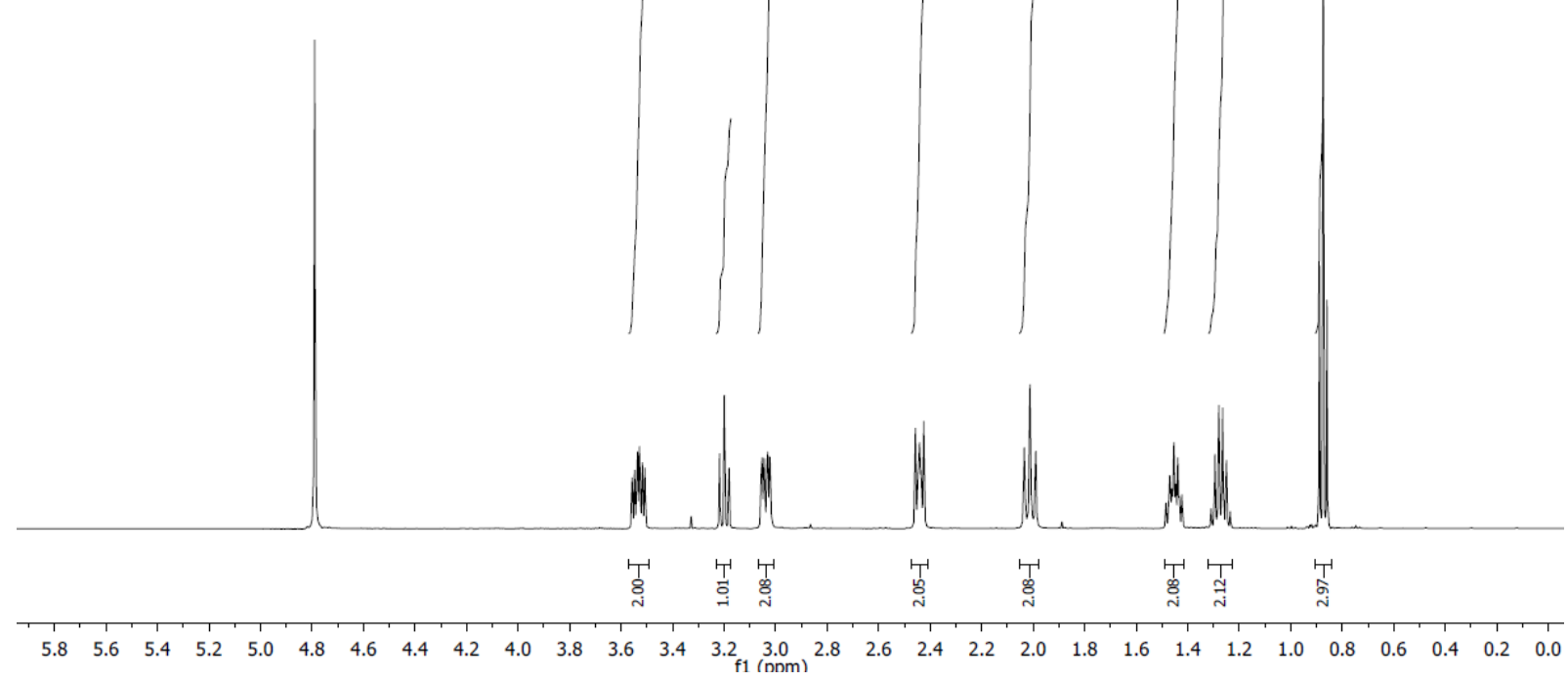<smiles>CCCCN1C[C@H](O)[C@H](O)[C@H](O)C1</smiles>

(3R,4r,5S)-1-butylpiperidine-3,4,5-triol (103)

${ }^{13} \mathrm{C}$ NMR, $\mathrm{D}_{2} \mathrm{O}, 125 \mathrm{MHz}$

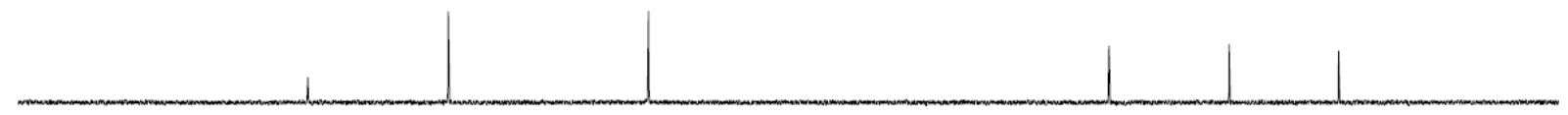

$\begin{array}{lllllllllllllllllllll}1 & 1 & 90 & 85 & 80 & 75 & 70 & 65 & 60 & 55 & \underset{\mathrm{f} 1(\mathrm{ppm})}{1} & 40 & 35 & 30 & 25 & 20 & 15 & 10 & 5 & 0\end{array}$




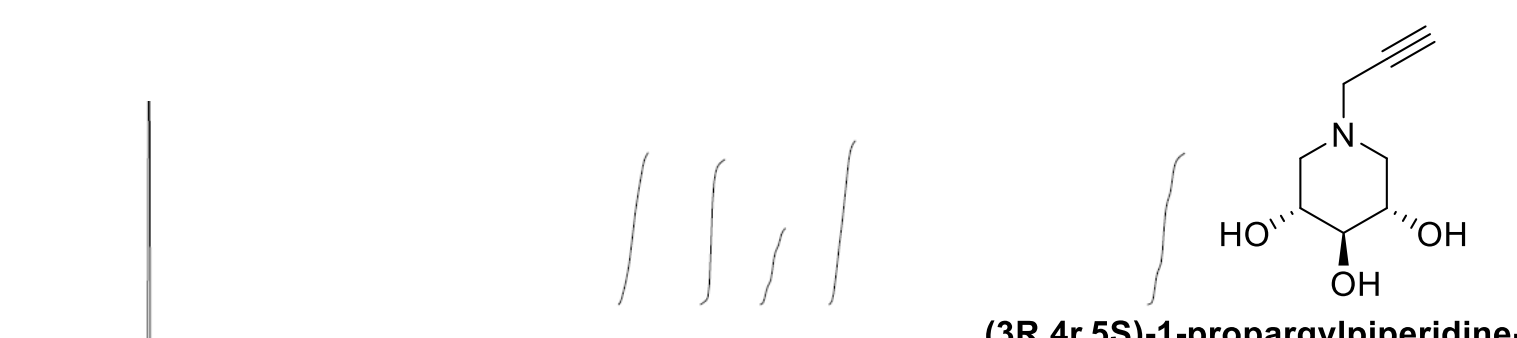

(3R,4r,5S)-1-propargylpiperidine-3,4,5-triol (104)

${ }^{1} \mathrm{H}$ NMR, $\mathrm{D}_{2} \mathrm{O}, 500 \mathrm{MHz}$
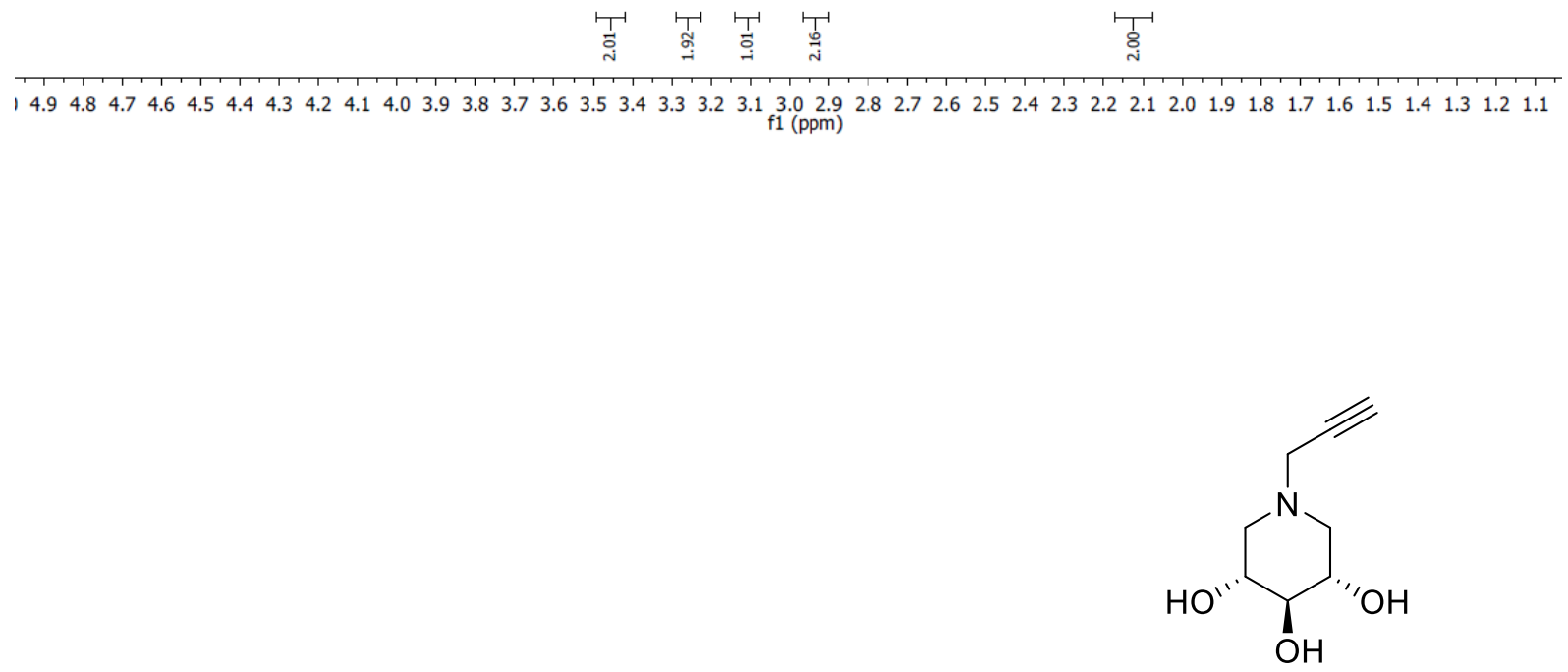

(3R,4r,5S)-1-propargylpiperidine-3,4,5-triol (104)

${ }^{13} \mathrm{C} N M R, \mathrm{D}_{2} \mathrm{O}, 125 \mathrm{MHz}$

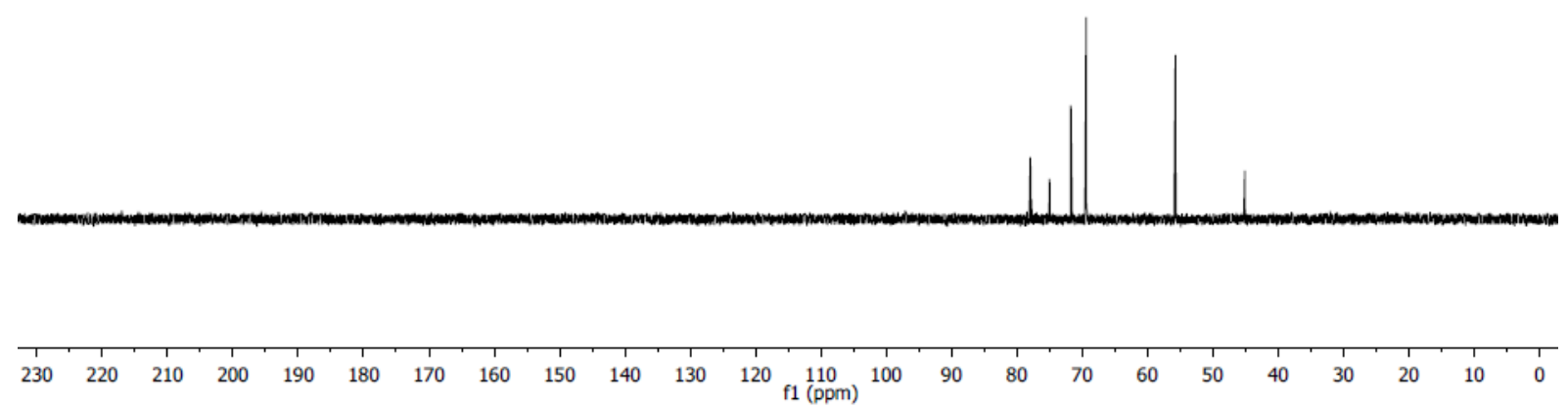



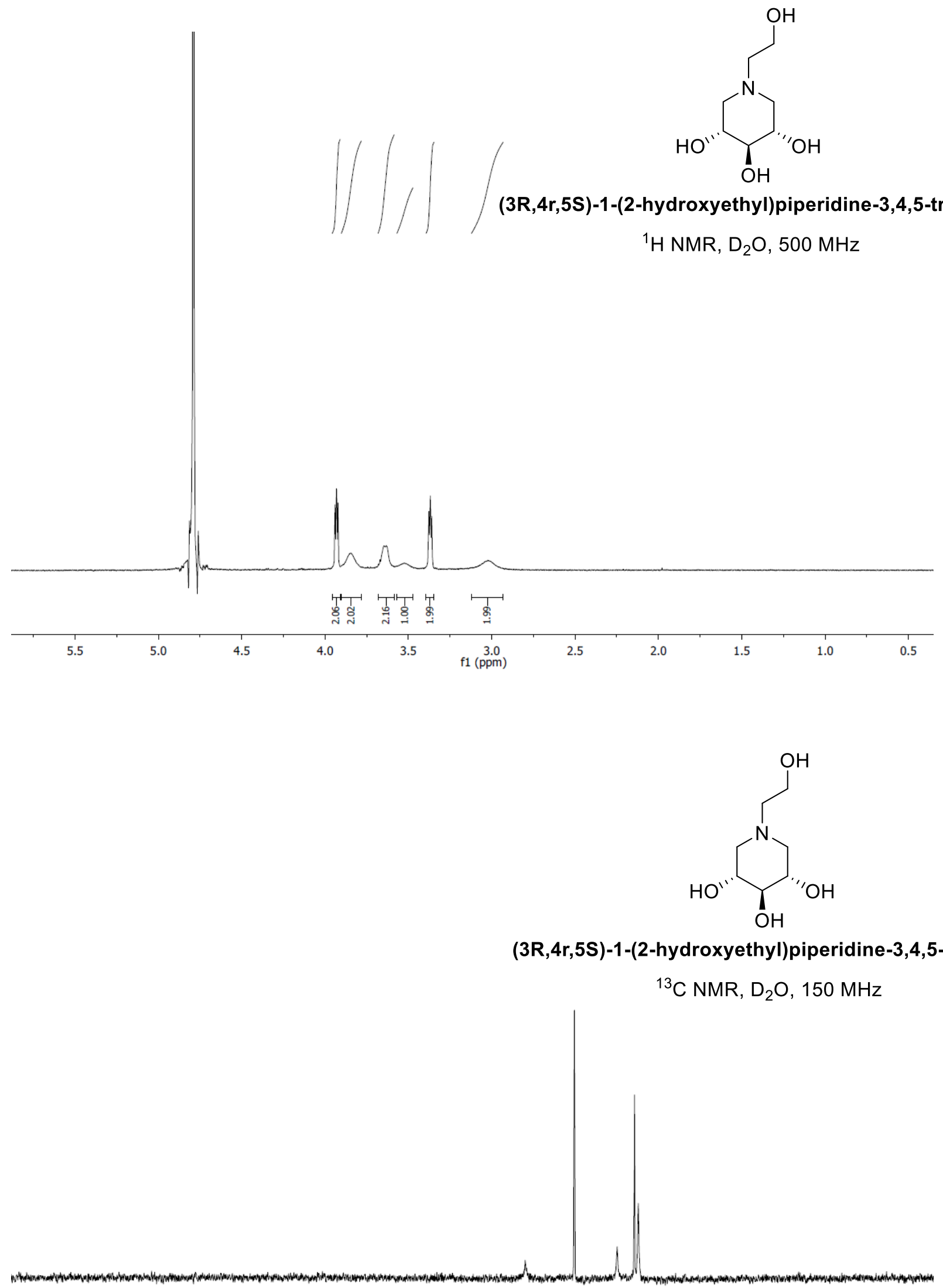

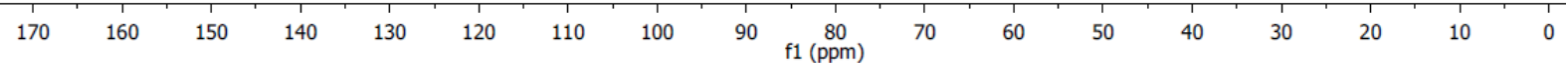




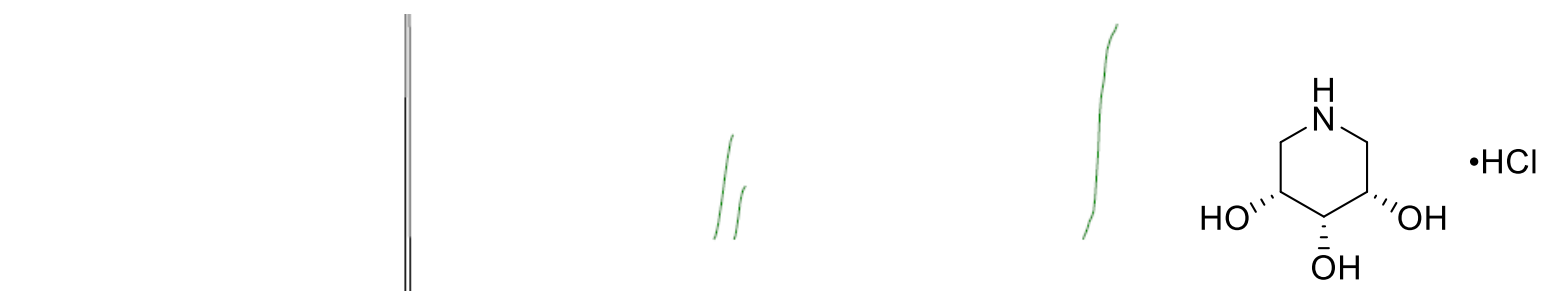

(3R,4s,5S)-piperidine-3,4,5-triol (31)

${ }^{1} \mathrm{HNMR}, \mathrm{D}_{2} \mathrm{O}, 500 \mathrm{MHz}$
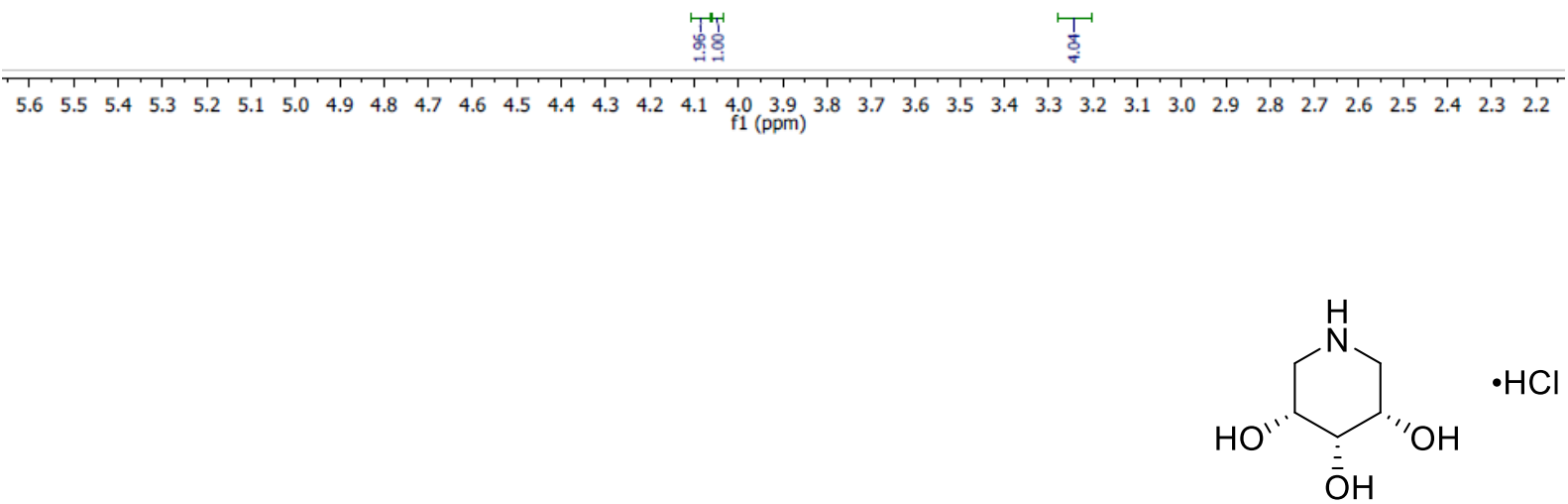

(3R,4s,5S)-piperidine-3,4,5-triol (31)

${ }^{13} \mathrm{C}$ NMR, $\mathrm{D}_{2} \mathrm{O}, 125 \mathrm{MHz}$ 


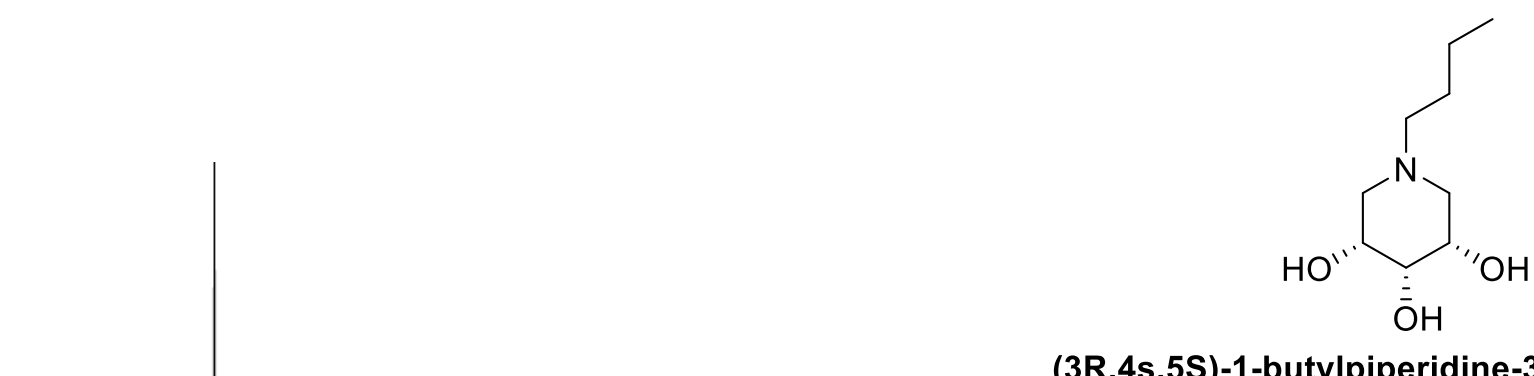

(3R,4s,5S)-1-butylpiperidine-3,4,5-triol (45)

${ }^{1} \mathrm{H}$ NMR, $\mathrm{D}_{2} \mathrm{O}, 500 \mathrm{MHz}$
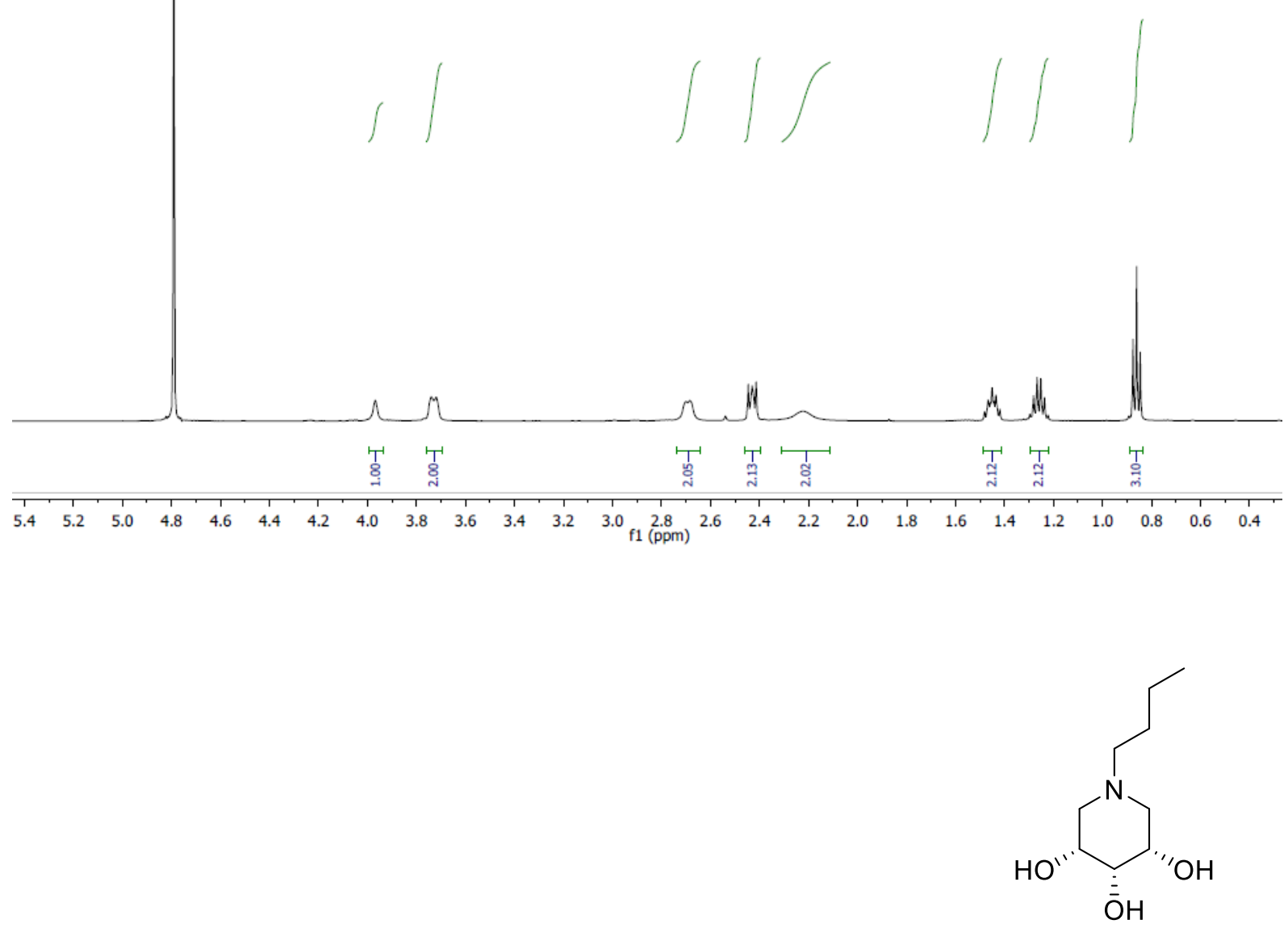

(3R,4s,5S)-1-butylpiperidine-3,4,5-triol (45)

${ }^{13} \mathrm{C}$ NMR, $\mathrm{D}_{2} \mathrm{O}, 150 \mathrm{MHz}$
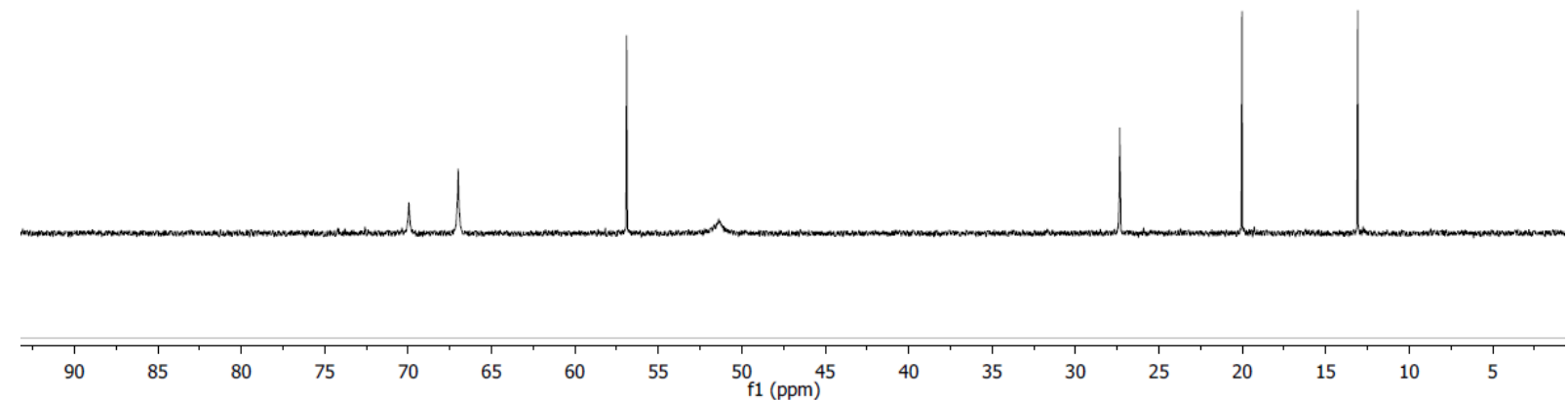


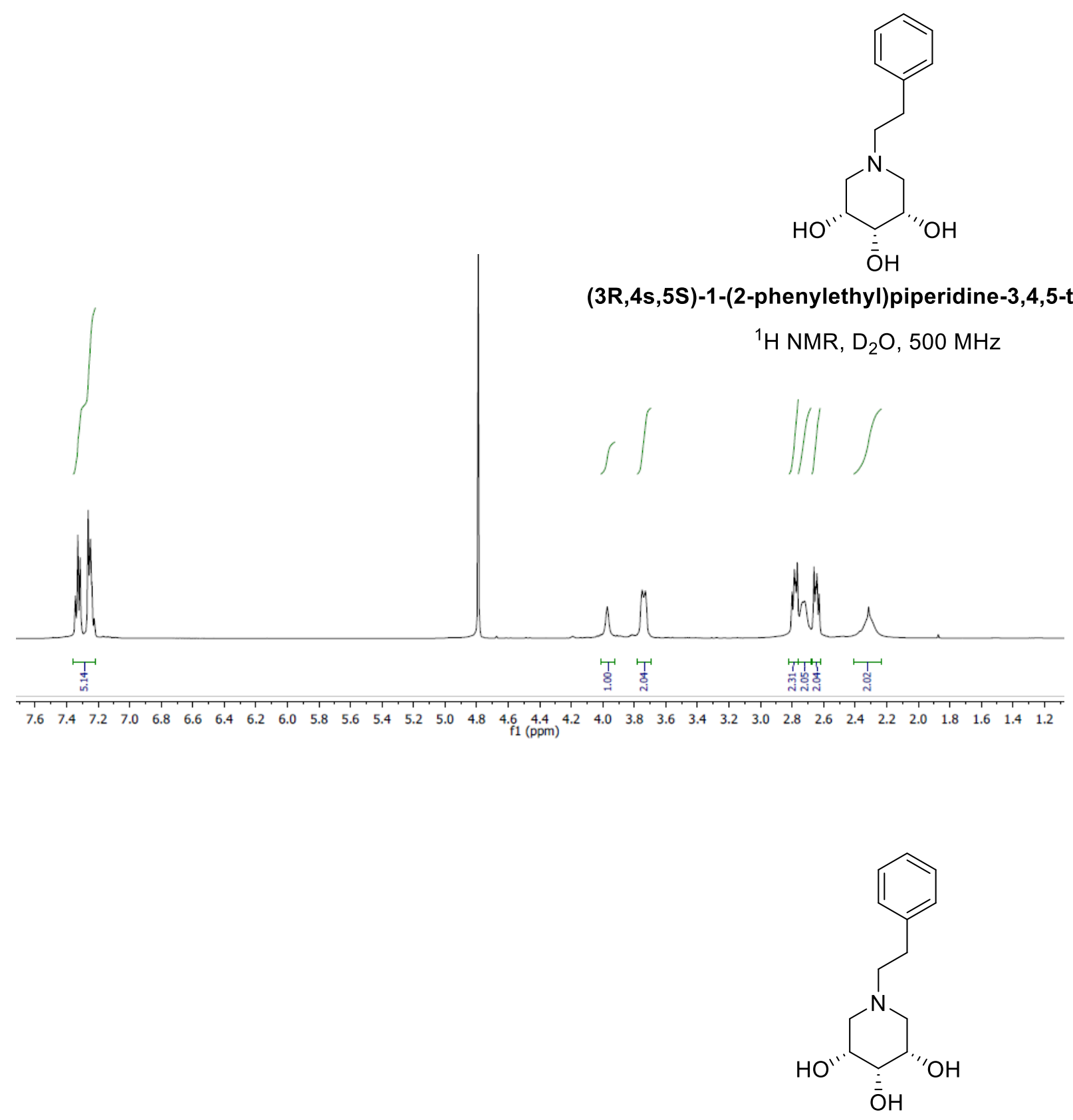

(3R,4s,5S)-1-(2-phenylethyl)piperidine-3,4,5-triol (113)

${ }^{13} \mathrm{C} \mathrm{NMR}, \mathrm{D}_{2} \mathrm{O}, 125 \mathrm{MHz}$

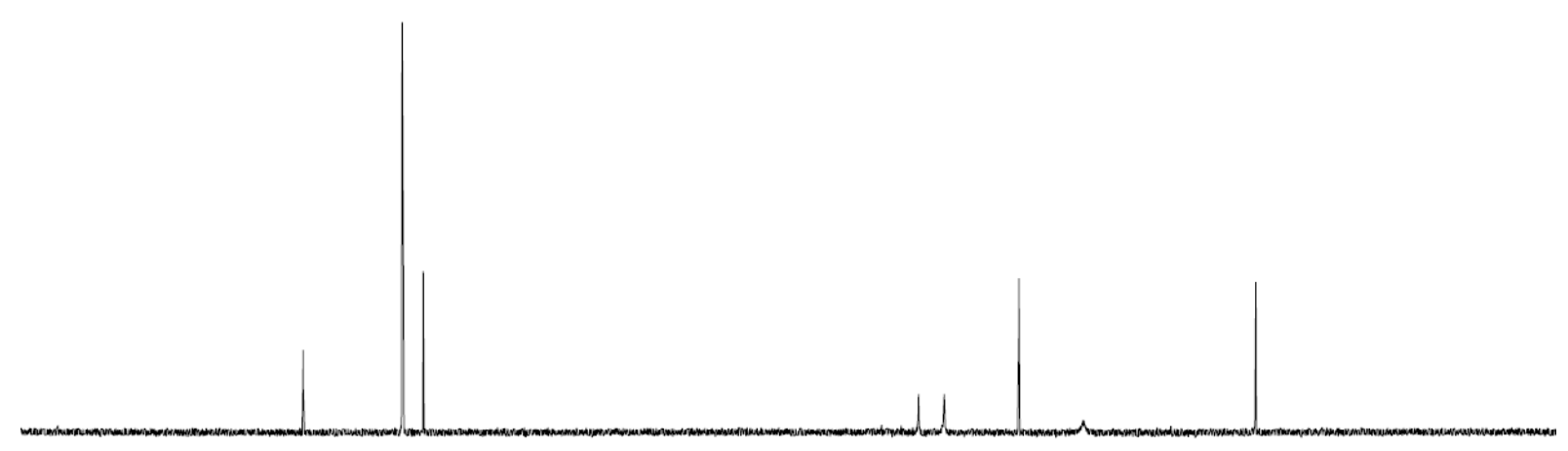

\begin{tabular}{|c|c|c|c|c|c|c|c|c|c|c|c|c|c|c|c|}
\hline 170 & 160 & 150 & 140 & 130 & 120 & 110 & 100 & ${ }^{90}{ }_{\mathrm{f} 1(\mathrm{ppm})} 80$ & 70 & 60 & 50 & 40 & 30 & 20 & 10 \\
\hline
\end{tabular}




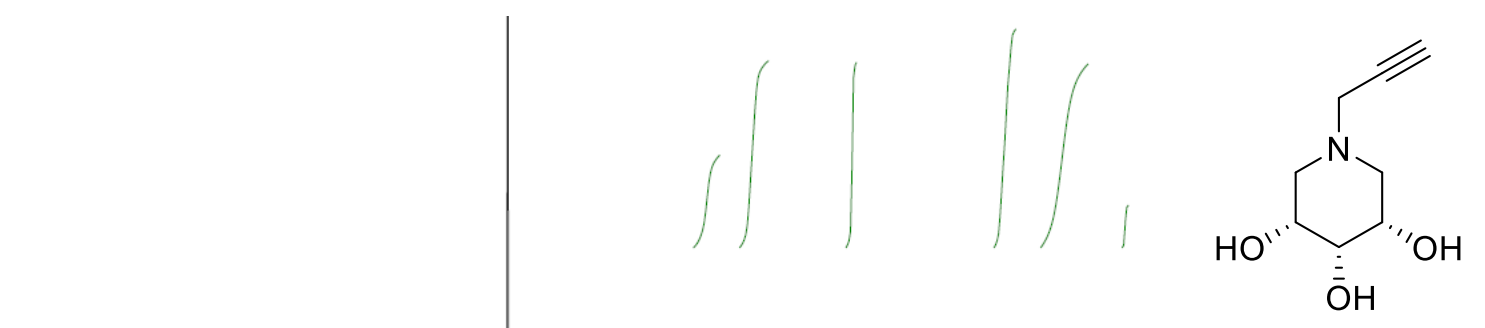

(3R,4s,5S)-1-propargylpiperidine-3,4,5-triol (114)

${ }^{1} \mathrm{H}$ NMR, $\mathrm{D}_{2} \mathrm{O}, 500 \mathrm{MHz}$

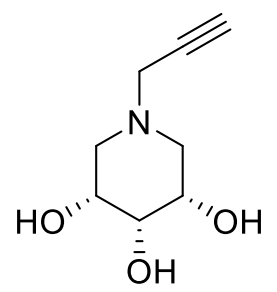

(3R,4s,5S)-1-propargylpiperidine-3,4,5-triol (114)

${ }^{13} \mathrm{C} \mathrm{NMR}, \mathrm{D}_{2} \mathrm{O}, 125 \mathrm{MHz}$ 

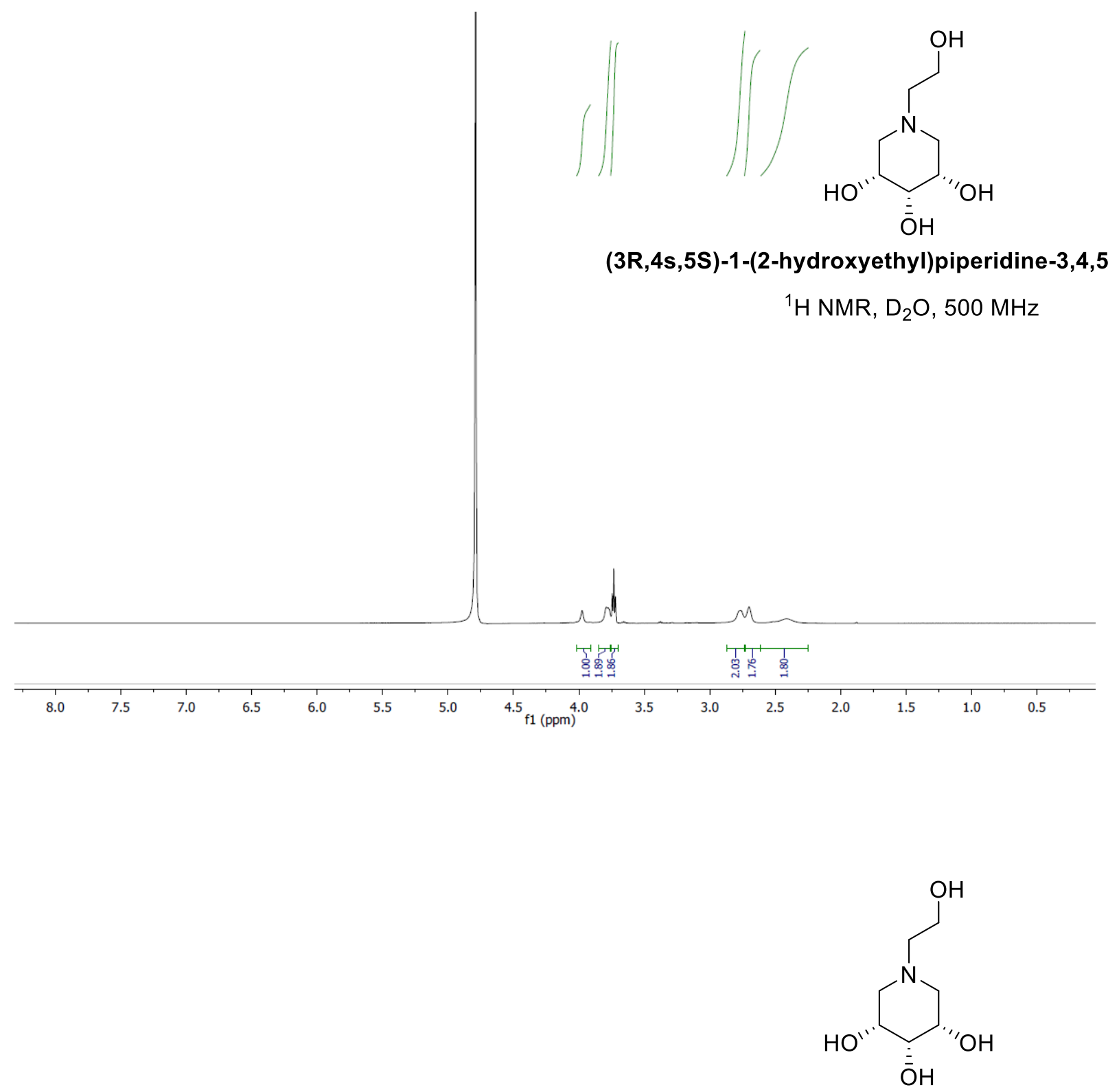

(3R,4s,5S)-1-(2-hydroxyethyl)piperidine-3,4,5-triol (115)

${ }^{13} \mathrm{C} \mathrm{NMR}, \mathrm{D}_{2} \mathrm{O}, 150 \mathrm{MHz}$

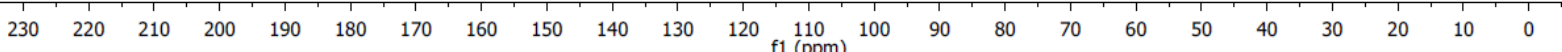




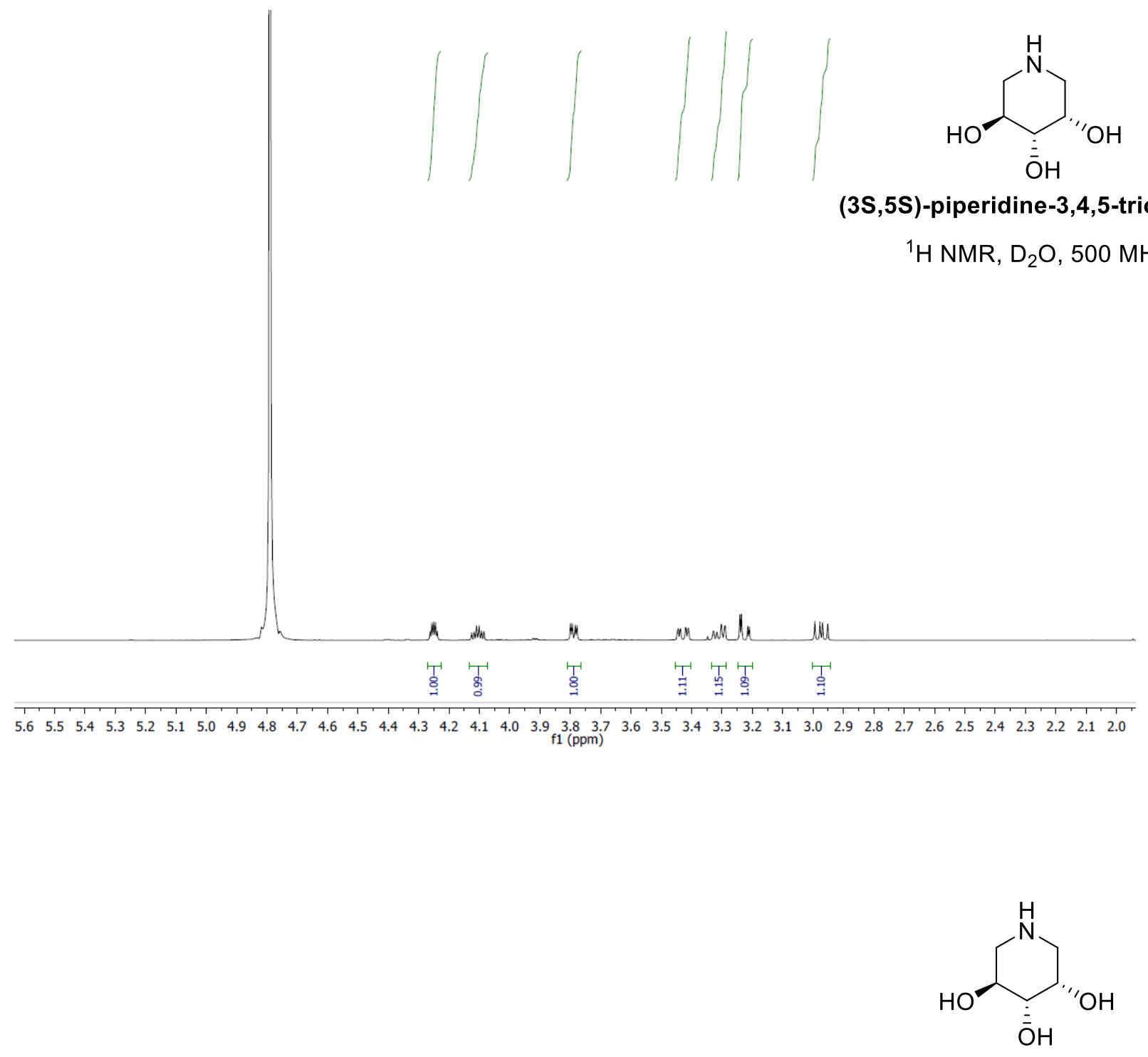

(3S,5S)-piperidine-3,4,5-triol (33)

${ }^{13} \mathrm{C} N M R, \mathrm{D}_{2} \mathrm{O}, 125 \mathrm{MHz}$

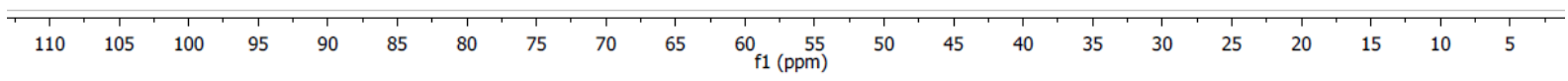




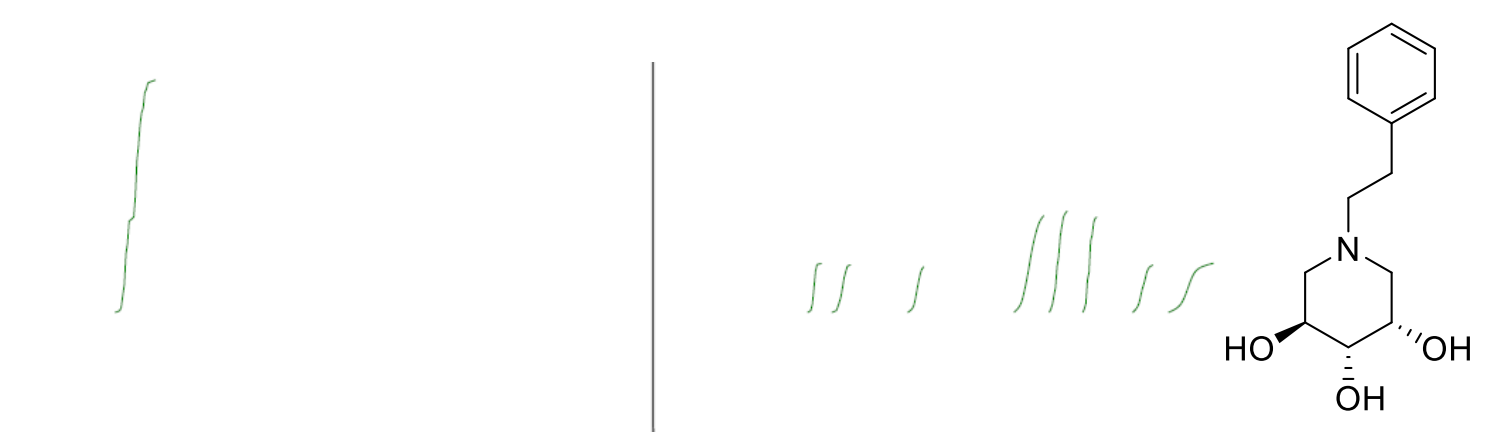

(3S,5S)-1-(2-phenylethyl)piperidine-3,4,5-triol (121)

${ }^{1} \mathrm{H}$ NMR, $\mathrm{D}_{2} \mathrm{O}, 500 \mathrm{MHz}$
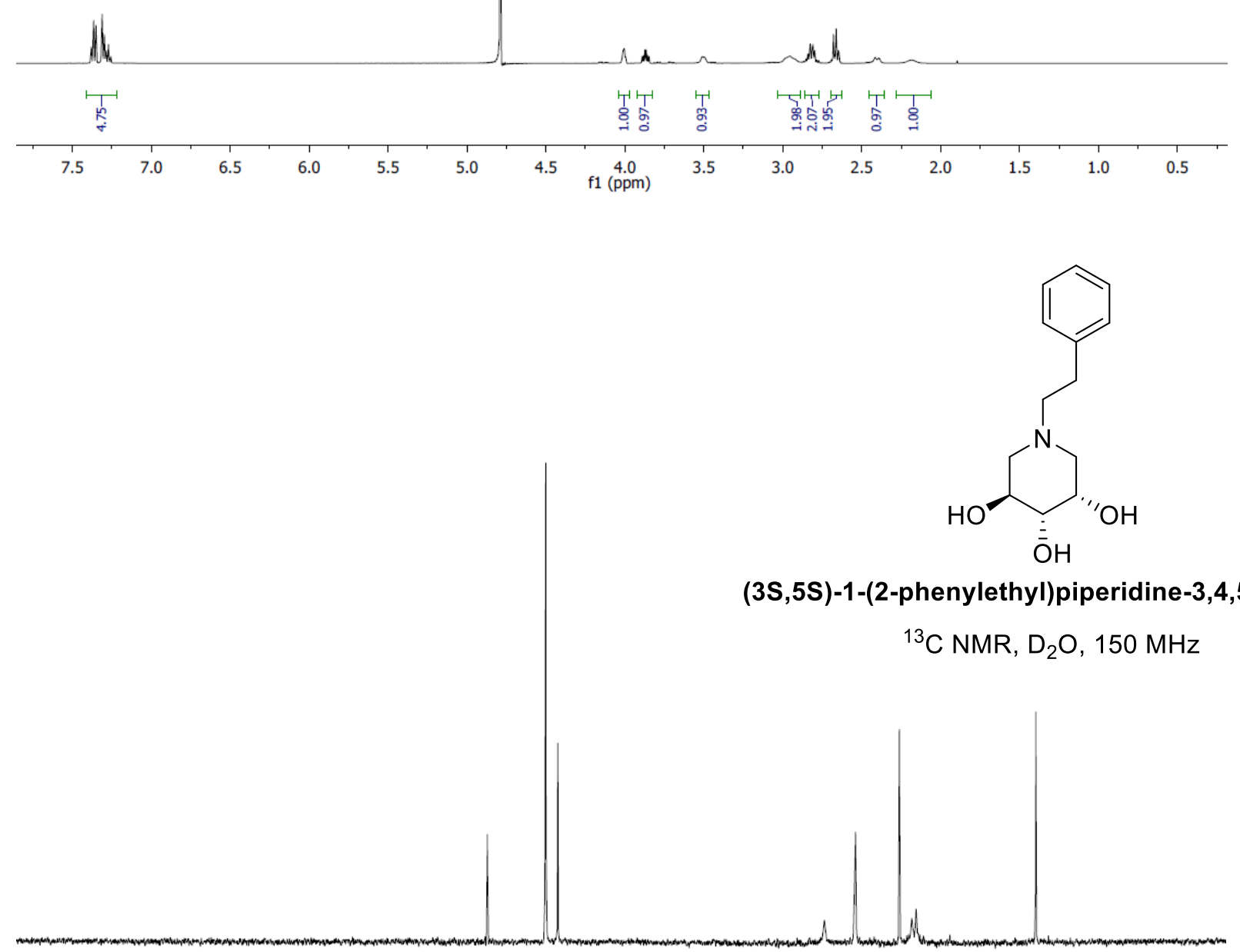

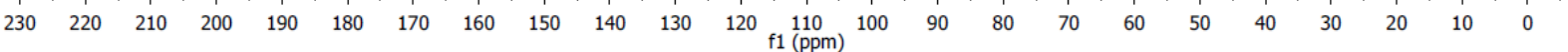



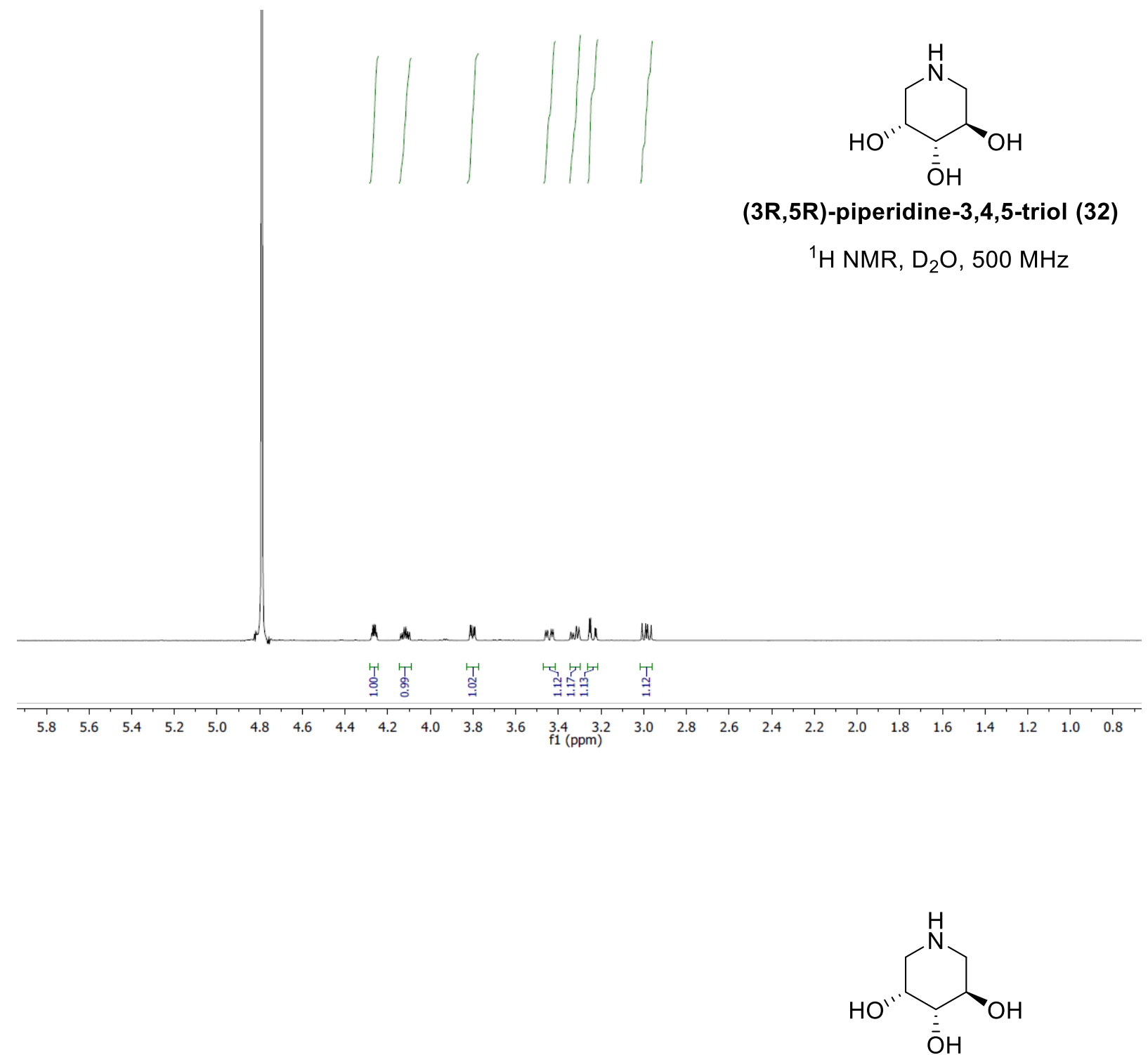

(3R,5R)-piperidine-3,4,5-triol (32)

${ }^{13} \mathrm{C} N M R, \mathrm{D}_{2} \mathrm{O}, 125 \mathrm{MHz}$

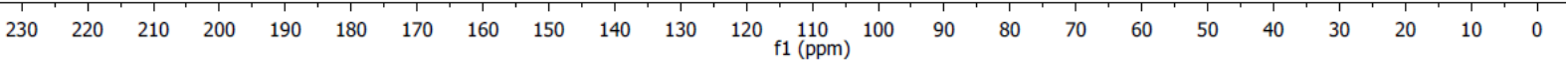



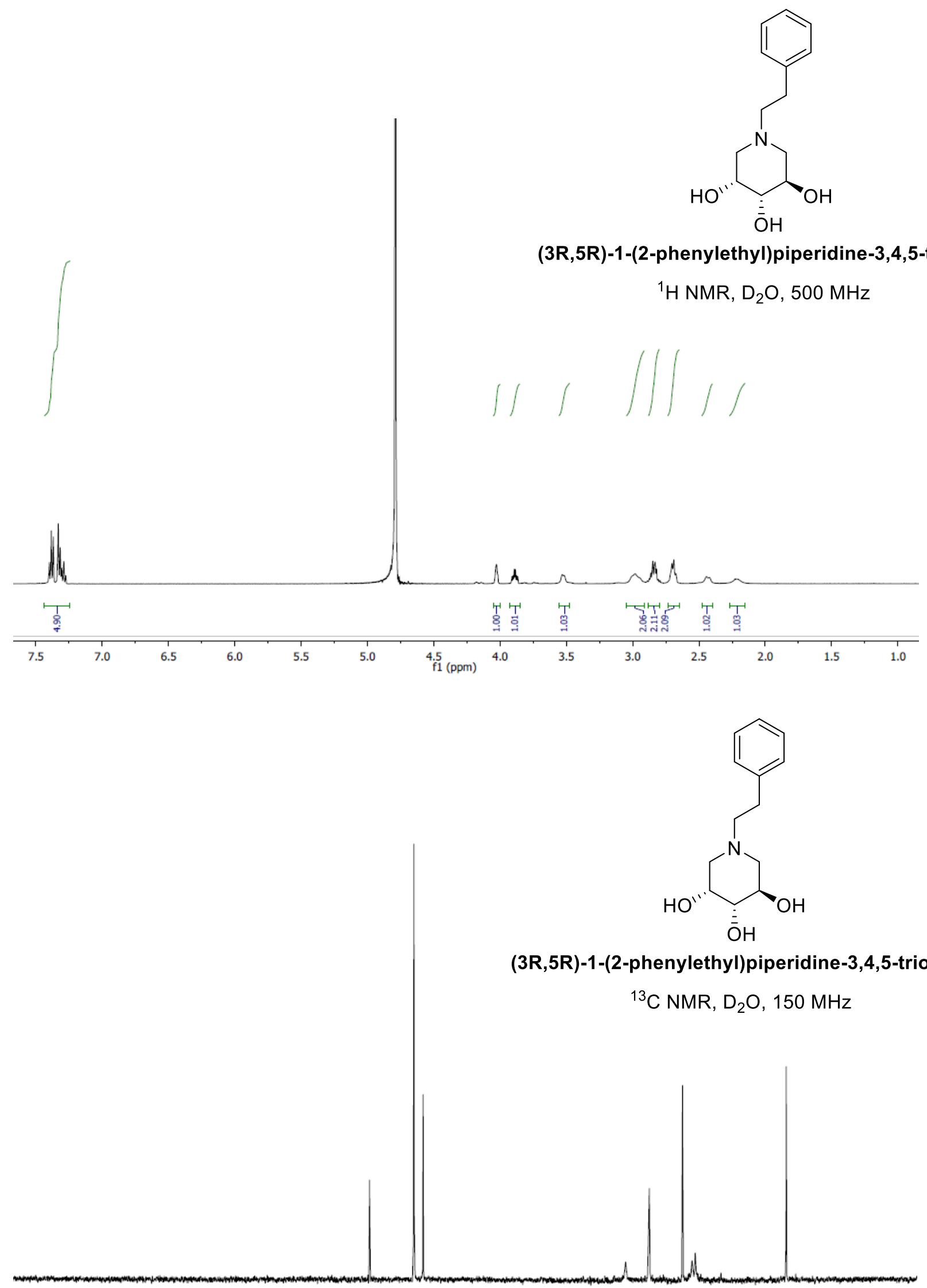